\title{
Preliminary Investigations of the Thermal Energy Grid Concept
}

\author{
M. Olszewski
}

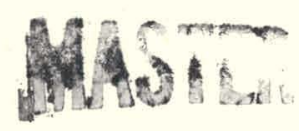

\section{OAK RIDGE NATIONAL LABORATORY}




\section{DISCLAIMER}

This report was prepared as an account of work sponsored by an agency of the United States Government. Neither the United States Government nor any agency Thereof, nor any of their employees, makes any warranty, express or implied, or assumes any legal liability or responsibility for the accuracy, completeness, or usefulness of any information, apparatus, product, or process disclosed, or represents that its use would not infringe privately owned rights. Reference herein to any specific commercial product, process, or service by trade name, trademark, manufacturer, or otherwise does not necessarily constitute or imply its endorsement, recommendation, or favoring by the United States Government or any agency thereof. The views and opinions of authors expressed herein do not necessarily state or reflect those of the United States Government or any agency thereof. 


\section{DISCLAIMER}

Portions of this document may be illegible in electronic image products. Images are produced from the best available original document. 


\section{Printed in the United States of America. Available from National Technical Information Service \\ U.S. Department of Commerce \\ 5285 Port Royal Road, Springfield, Virginia 22161 \\ Price: Printed Copy $\$ 5.50 ;$ Microfiche $\$ 3.00$}

This report was prepared as an account of work sponsored by the United States Government. Neither the United States nor the Energy Research and Development Administration/United States Nuclear Regulatory Commission, nor any of their employees, nor any of their contractors, subcontractors, or their employees, makes any warranty, express or implied, or assumes any legal liability or responsibility for the accuracy, completeness or usefulness of any information, apparatus, product or process disclosed, or represents that its use would not infringe privately owned rights. 
Contract No. W-7405-eng-26

Engineering Technology Division

PRELIMINARY INVESTIGATIONS OF THE THERMAL ENERGY GRID CONCEPT

M. Olszewski

Contributors

J. G. Delene

J. E. Christian

J. T. Meador

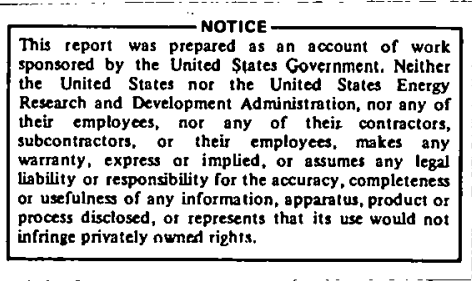

Manuscript Completed - September 26, 1977

Date Published - October 1977

NOTICE: This document contains information of a preliminary nature. It is subject to revieion or correction and thercfore does not represent a final report.

Prepared by the OAK RIDGE NATIONAL LABORATORY

Oak Ridge, Tennessee 37830 operated by

UNION CARBIDE CORPORATION

for the

ENERGY RESEARCH AND DEVELOPMENT ADMINISTRATION 
THIS PAGE

WAS INTENTIONALLY

LEFT BLANK 
Page

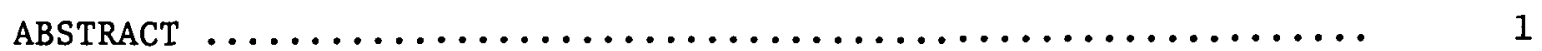

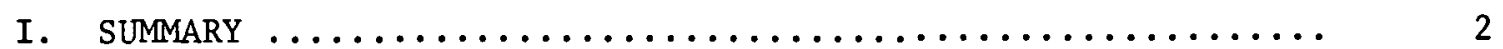

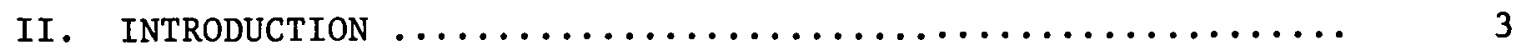

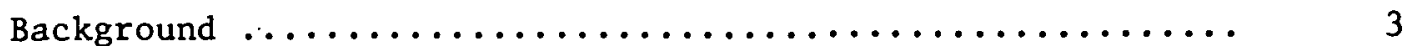

Overview of the Proposed System ................... 5

Scope and Method of the Present Study ................ 8

III. REVIEW OF CURRENT STATUS OF DISTRICT HEATING $\ldots \ldots \ldots \ldots \ldots \ldots$.

Status of District Heatng in the United States ........... 9

Status of District Heating Outside the United States ...... 13

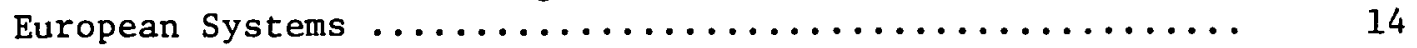

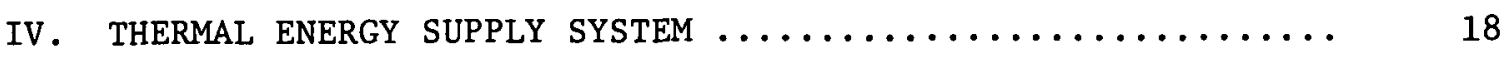

Description of the Heat Supply System $\ldots \ldots \ldots \ldots \ldots \ldots \ldots \ldots$

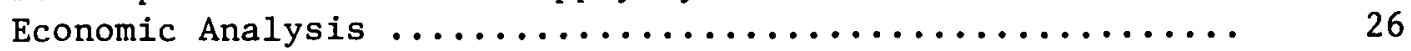

Cost of Supplying Heat to the Thermal Grid ........... 32

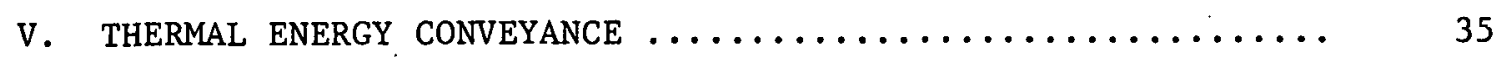

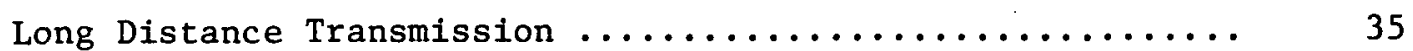

Subregion Distribution ....................... 40

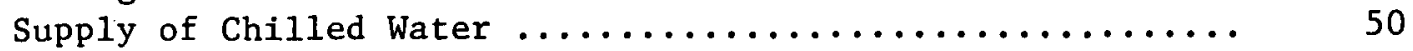

Impact of Improved Distribution Technology ............ 55

VI. ECONOMICS AT POINT OF CONSUMPTION ............... 56

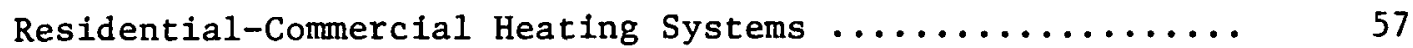

Residential-Commercial Heat1ng Breakeven Economics ....... 68

Industrial Heat Supply Breakeven Economics ............. 80

Residential-Commercial Cooling Breakeven Economics ....... 84

VII. ASSESSMENT OF THE THERMAL GRID CONCEPT $\ldots \ldots \ldots \ldots \ldots \ldots \ldots . .$.

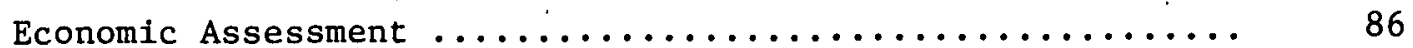

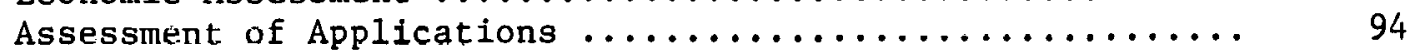

Institutional Considerations Concerning Implementation .... 98

Factors to be Considered in Further Studies ............ 99

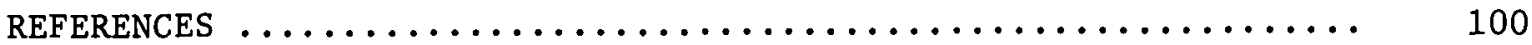




\title{
PRELIMINARY INVESTIGATIONS OF THE
} THERMAL ENERGY GRID CONCEPT

\author{
M. Olszewski
}

\section{ABSTRACT}

This study examines, in a preliminary manner, the feasibility of the thermal grid concept. This concept essentially envisions the supply of heat to a long distance transmission line from a dual purpose nuclear or coal-fired power plant. The transmission line delivers heat to a subregion distribution network which delivers it to the consumer. District chilled water supply is also considered using heat from the grid to power steam turbine driven water chillers.

Candidate technologies for generation, transmission, and distribution of thermal energy are identified and assessed. Potential applications, including both industrial use and residential space conditioning and hot water supply, are evaluated.

The analysis results indicate that high temperature hot water transmission lines are favored for longer distances while steam lines may be acceptable for shorter distances. It is also evident that thermal grid heat is more economically competitive for new applications, as opposed to retrofit situations, in the residential-commercial sector. The two applications are about equally feasible in the industrial sector. The results further indicate that thermal grid heat is most competitive in areas of high heat load density and expensive fuel costs.

It appears that the thermal grid service area should include the industrial sector as a base load. The multifamily residential-commercial sector space and water heating loads can be added to the service area to maximize utilization of the transmission line and maintain low transmission costs. Supply of chilled water to the multifamily residentialcommercial sector can also be included for new applications to increase the transmission line use factor.

Institutional issues such as rate schedules for heat from dual-purpose plants and integration of utility district implement the thermal grid soncept.

The thermal grid concept appears to be economically and technically feasible, when compared to oil and electric systems in the multifamily residential-commercial sector and coal- or oil-fired systems in the industrial sector, and should be explored in greater detail. Future programs should concentrate on developing thermal grid economics for specific sites and identifying hardware needs to implement the concept. 
I. SUMMARY

System costs for the heat generation, transmission and distribution components of the thermal grid system were developed. Consumer breakeven prices for heat and chilled water from the grid have also been estimated in an effort to determine which consuming sectors can economically be supplied by the thermal grid.

The results indicate that high temperature hot water transmission lines are favored for long distances for economic and technological reasons. Steam transmission is feasible for shorter distancés.

Supply of thermal grid heat is more economically attractive for new applications than for retrofit situations in the residential-commercial sector. Within the industrial region the difference between the two applications is small, slightly favoring new applications. Supplying the single family residence sector was found to generally be uneconomical. Therefore, it is unlikely that this sector would be served by the grid.

Thermal grid heat is competitive with standard oil systems for new applications in the multifamily residential-commercial, single family residential and industrial sectors for transmission distances of 64,13 : and $24 \mathrm{~km}$ ( 40,8 and 15 miles) respectively. This analysis also indicated that thermal grid heat is most competitive in areas of high heat load density and expensive fuel costs. Therefore, although the industrial sector possesses the highest load density, its relatively low heat costs cause the sector to be less attractive than the multifamily residential sector.

Supply of chilled water was found to be viable only for new applications in the multifamily residence-commercial sector.

The assessment essentially indicated that heat from the thermal grid was economically competitive with oil and electric systems in the multifamily residential-commercial sector to meet space and domestic water heating demands. Supply of chilled water to this sector was also found to be economically feasible. Industrial process steam could also be supplied economically by the thermal grid to industries using coal- or oil-fired systems. 
The results of the analysis further indicated that the thermal grid service area should include the industrial sector and the multifamily residential-commerical sector space and water heating loads. A system dominated by the industrial load is favored because of the relatively constant base load. Supply of the multifamily residential-commercial dominated load area, however, is also a feasible option.

It appears that the use of coal-fired or nuclear systems to supply heat to the grid results in approximately the same economic transmission distances. It therefore appears that these heat supply systems are competitive with each other for thermal energy supply.

Institutional issues such as rate schedules for heat from dualpurpose plants and integration of utilfty district heat and electrical generation functions must be addressed before implementation of the thermal grid concept can be accomplished.

The thermal grid concept appears to be economically and technically.. feasible and should be explored in greater depth. Future programs should concentrate on developing the economics of the thermal grid system for three specific sites. These sites should include an industrial dominant market, a residential-commercial dominant market and a balanced load market. System load growth and thermal storage questions should also be investigated. Equipment needs, especially for cogeneration of heat and power, should also be examined.

\section{INTRODUCTION}

\section{Background}

Approximately $40 \%$ of the primary energy consumed in the United States is for applications requiring relatively low temperature $\left[\leq 177^{\circ} \mathrm{C}\left(350^{\circ} \mathrm{C}\right)\right]$ thermal energy. An analysis of these applications (using Refs. 1-4) indicates the consumption pattern presented in Table 2.1.

These uses account for about 30 and $60 \%$ of our national consumption of petroleum and natural gas, respectively, equivalent to about 10 million barrels of oil per day. Given the energy situation in the United States today, it would be highly desirable to substitute domestic fuels with a 
Table 2.1. Low temperature heat consumption pattern in the U.S.

\begin{tabular}{|c|c|}
\hline Application & $\begin{array}{l}\% \text { of total U.S. } \\
\text { energy consumption }\end{array}$ \\
\hline Industrial process steam & 16 \\
\hline $\begin{array}{l}\text { Commercial and institutional space } \\
\text { conditioning }\end{array}$ & 5 \\
\hline $\begin{array}{l}\text { Residential space conditioning and hot water } \\
\text { Single family } \\
\text { Multifamily }\end{array}$ & $\begin{array}{r}13 \\
4\end{array}$ \\
\hline Total & $\overline{38}$ \\
\hline
\end{tabular}

longer term resource base, such as nuclear or coal, to supply this thermal energy. If nuclear fuels are used to supply a significant portion of the low to moderate temperature energy needs of a region, central thermal generating plants feeding a regional thermal grid seem to be essential. The thermal grid concept for supplying energy in the form of heat is analogous to present electrical grids for the transport and distribution of electrical energy.

A recent evaluation ${ }^{5}$ of nuclear and coal alternatives for supplying industrial steam indicated that steam from commercial nuclear plants was economically competitive with the alternatives considered. Small nuclear plants were also evaluated and appeared to be competitive under some conditions.

A study ${ }^{6}$ performed by Dow Chemical Company for the National Science Foundation indicated that industrial steam is predominantly generated today in inefficient boilers that should be replaced by more efficient dual-purpose electricity-steam plants. Dual-purpose central power stations were identified as one means of increasing efficiency. Another Dow study, 4 conducted for the Oak Ridge National Laboratory, identified 160 locations in the United States where there is an industrial steam load of $63 \mathrm{~kg} / \mathrm{sec}(500,000 \mathrm{lb} / \mathrm{hr}$ ) or more within a $3.2 \mathrm{~km}$ (2 miles) radius, and 22 locations having a steam load of greater than $504 \mathrm{~kg} / \mathrm{sec}$ $\left(4 \times 10^{6} \mathrm{lb} / \mathrm{hr}\right)$ within a $16.1 \mathrm{~km}$ (10 mile) radius. 
While industrial steam system retrofitting to accept steam from the grid may be feasible, retrofitting appears to increase in difficulty as the user gets smaller. Nevertheless, foreign countries such as sweden 6 and West Germany ${ }^{7}$ are considering piping heat to individual residences. Hence it appears that the entire spectrum of users should be considered.

\section{Overview of the Proposed System}

The thermal grid essentially consists of three subsystems: the heat supply system, the long distance heat transmission system, and the heat distribution network within the consuming sector.

Cogeneration of heat and power is employed to supply thermal energy to the thermal grid. The two principal methods for obtaining heat from the dual purpose power cycle are illustrated in Figs. 2.1 and 2.2. Figure 2.1 illustrates the use of turbine extraction steam to supply heat to the thermal grid. In this technique prime steam from the steam generator and turbine extraction steam are used to heat the thermal grid transport fluid. By regulating the extraction flow rates, the thermal grid supply temperature can be adjusted to the desired temperature. Typically, heat is supplied to the grid at temperatures of $149-204^{\circ} \mathrm{C}$ $\left(300-400^{\circ} \mathrm{F}\right)$.

The use of back-pressure turbines to supply heat to the grid is illustrated schematically in Fig. 2.2. In this application several of the low pressure turbine stages are removed and the turbine exhaust temperature raised to $149-204^{\circ} \mathrm{C}\left(300-400^{\circ} \mathrm{F}\right)$ depending upon the return temperature from the grid. Since the thermal grid would only use about $20 \%$ of the energy supplied to the turbines, it can only accommodate a portion of the total steam flow. Conventional low-pressure turbines are, therefore, used in addition to the back-pressure turbine.

Once the heat has been supplied to the grid it is transported to Lle consumer via a transuission pipelinc. Using a suttahle transport fluid the heat is pumped to the consuming sectors.

When the heat is delivered to the consuming sectors it is distributed to the individual industrial, residential, and commercial customers Llirough a distribution network. This distribution system is similar to that typically used for district heating systems. 


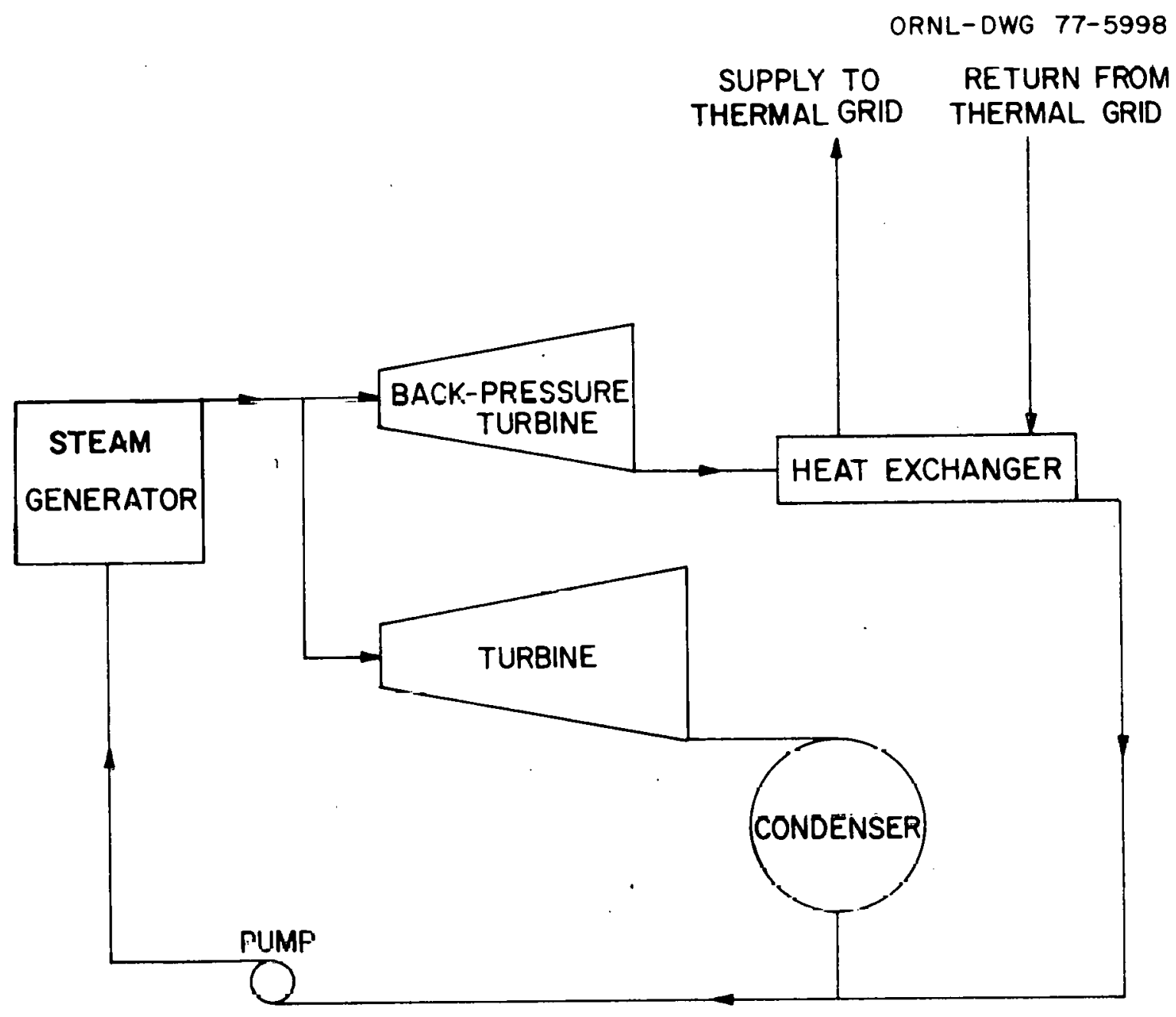

Fig. 2.1. Schematic of thermal grid heat supply using back-pressure turbine. 


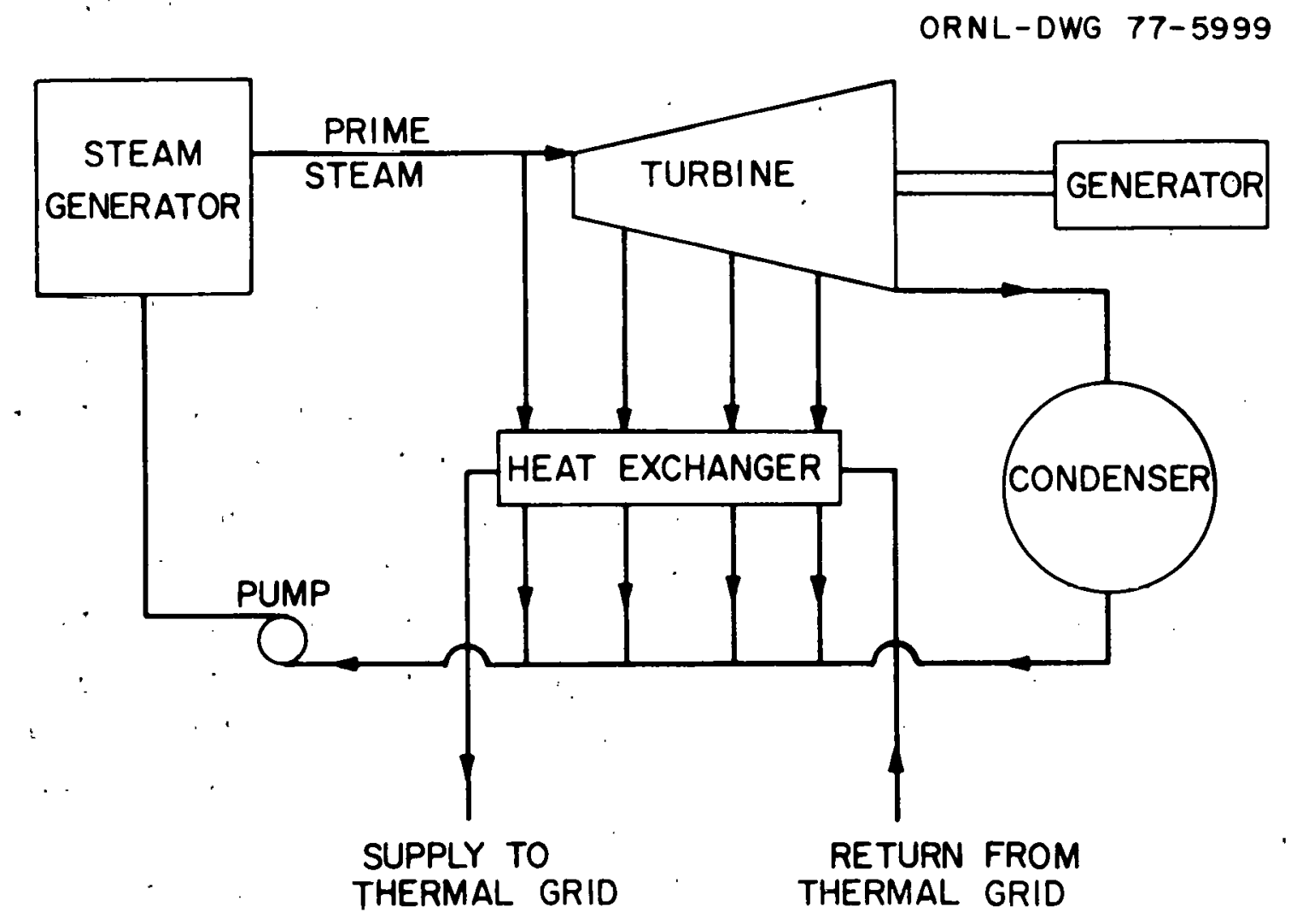

Fig. 2.2. Schematic of thermal grid heat supply using turbine extraction steam. 
It is, therefore, evident that the thermal grid concept is essentially an extension of traditiona1 district heating concepts. Large scale cogeneration plants were included in the system in an effort to raise the thermodynamic efficiency of generating power and provide an economical source of heat for the grid. Long distance heat transmission (also known as telethermics) is considered in an effort to overcome siting restrictions for coal and nuclear facilities.

\section{Scope and Method of the Preacnt Study}

The purpose of this study is to examine, fn a prodiminory mnnner, the feasibility of the thermal grid concept. Candidate technologies for generation, transmission and distribution of thermal energy are identified and assessed. Potential applications are evaluated in an effort to indicate those applications that appear to provide the best potential for use of thermal grid energy. Potential applications include both industrial use and residential space conditioning and hot water supply.

The thermal grid concept essentially envisions the supply of heat to a long distance transmission line from a dual-purpose nuclear or coalfired power plant. The transmission line then transports heat to a subregion distribution system which deljvers it to the customer. Clilled water supply, using heat from the thermal grid to power steam turbine driven water chillers, is also considered.

In order to evaluate the concept, costs* are developed for each of the components outlined above. An evaluation is also made to determine what price the consumer can afford to pay for energy from the grid by considering alternate conventional methods of space conditioning and steam supply. Using the system costs and customer breakeven prices, an assessment is made to determine if the thermal grid Goiltur appcaro to be economically feasible. The feasible applications are then rated by calculating the maximum allowable distance between the heat supply system and the consuming region. The rankings also consider technical criteria such as load pattern and distance from the heat source.

\footnotetext{
*A11 costs presented are in mid-1976 dollars.
} 
Institutional considerations concerning implementation of the concept are discussed and factors to be considered in future studies are identified.

III. REVIEW OF CURRENT STATUS OF DISTRICT HEATING

Essentially, the thermal grid concept is an extension of traditional district heating systems incorporating the industrial sector in the service area and utilizing heat from dual-purpose power plants. It is, therefore, appropriate that analysis of the system begins with a review of the current status of district heating.

This section presents a qualitative summary of the current status of district heating in the United States and in foreign countries. It should be noted that the term district heat generally refers to regional or town heating. It can also, as in some foreign literature, refer to small areas encompassing only a few blocks.

\section{Status of District Heating in the United States}

\section{Historical}

The beginnings of district heating in the United States can be traced back to 1877 in Lockport, New York, when Birdsill Holly installed a short underground steam pipe and heated a few homes from a central source. 8 Use of large scale district heating systems, however, did not occur until the early part of the twenticth century. At that tine electricity was generated in small power stations that exhausted steam directly to the atmosphere. Since these small generating stations were generally located near business and industrial districts, the use of this exhaust steam to, warm nearby buildings was an attractive proposition and many district heating systems were installed. The introduction of the condensing type of electrical generating plant and of the hydroelectric plant, coupled with the development of long distance electrical transmission, led to large central stations removed from business districts. This essentially eliminated the small noncondensing plants that supplied steam to the 
district heating systems. The district heating systems, therefore, were forced to use prime steam from the boilers.

Many early projects were not profitable due to inadequate rates or lack of proper metering devices. Also, during the transition from exhaust steam to live steam, great difficulty was experienced in readjusting the rates to reflect the increased cost of operation. These adverse economic conditions combined with the lack of engineering development to slow the early progress of district heating.

Since a majority of district heating systems originated with or were later ahsorbed by electric power companles, lusses incurred by the diotrict heating business were offset by the elecllical business. Thio situation existed unt1l adequate rates were set in properly selected territories thus enabling district heating to become a profitable venture.

\section{Current status}

Statistics $^{9}$ from the International District Heating Association (IDHA) for 1973 show a total annual utility steam sale, for heating, of $43 \mathrm{Tg}\left(94.6 \times 10^{9} \mathrm{lb}\right)$. It is estimated 10 that nonutility (government institutions, college campuses, etc.) district heating systems utilize a total quantity of steam about equal to the total ut1licy sales figure. Therefore, the total amount of steam used for dislricl lieating in 1973 was on the order of $86 \mathrm{Tg}\left(189.2 \times 10^{9} \mathrm{lb}\right)$. District heating, thus, satisfied approximately $1 \%$ of the demand for heating in the United States.

The IDHA 1973 statistics also indicate that $359 \mathrm{Gg}$ (791 million lb) of steam were sold to 31 installations to provide $93 \mathrm{MJ} / \mathrm{sec}(26,226$ tons) of refrigeration for chilled water production.

The growth rate for the top 14 district heating utilities over the past 14 years was about $31 / 2 \%$ pel year. Wh1lc thic growth rate is smaller than the industry average (about $5 \%$ ), it must be vicwed in light of the circumstances of the utilities and their service areas. These systems are generally located in the older center city areas of some of America's oldest and largest cities. Building and maintaining distribution systems in these core areas has become economically marginal for a variety of reasons. Years of underground construction, maintenance and replacement by various utilities such as water, gas, telephone, 
electricity, sanitary and storm sewers have congested the underground areas and makes routing of district heating distribution lines very difficult. These routing problems can significantly contribute to the cost of expanding the distribution system. For instance, installation of new mains in urban areas can cost from $\$ 492 / \mathrm{m}(\$ 150 / \mathrm{ft})$ to as much as $\$ 1312-\$ 3280 / \mathrm{m}$ $(\$ 400-\$ 1000 / f t)$.

As previously explained, district. heating systems in the United States were initiated using steam distribution systems. Early expansion of these systems also used steam because of customer requirements. Therefore, district heating utilities now find themselves committed to steam distribution because retrofitting to an alternate distribution system is economically unjustifiable.

The steam distribution systems are generally designed for a pressure drop of $2.2-4.4 \mathrm{kPa} / 1000 \mathrm{~m} \mathrm{(1-2} \mathrm{psi} / 100 \mathrm{ft}$ ) of pipe length. 10 With these relatively large pressure drops in the distribution system long distance, distribution of energy is prohibitive. Therefore, most district heating systems tend to keep their maximum distribution distances small by concentrating on customers that are relatively close to the steam generating plant.

In addition, regulated district heating utilities often obtain a low rate of return (on the order of $3-5 \%$ ) from their district heating business. 11 The low rate of return on investment coupled with the large capital expenditures for network expansion and the need to serve small areas has combined to constrain the growth of urban district heating systems to areas having a high load density. Most of the recent growth in urban systems has been achieved by adding new customers that could be served by the existing distribution system or by expanding the distribution system into urban renewal areas. Expansion into urban renewal areas has provided an opportunity to supply steam and chilled water, as done in Hartford, Conn., 12 Pittsburgh, Pa., 13 and Co-op City, N.Y.14 Production of chilled water has resulted in a higher annual use factor for the district heating system.

Perhaps the greatest expansion of the district heating industry, in recent years, has taken place on college campuses and in new regional shopping and living areas. Installation of a district heating 
distribution network in these areas is simplified because they are not hampered by the congestion of urban core areas. In addition to adding chilled water distribution to increase the annual load factor, these new systems provide an opportunity for technical innovation. The system at Ohio State University is a prime example; warm water for heating is supplied at temperatures between $38-93^{\circ} \mathrm{C}\left(100-200^{\circ} \mathrm{F}\right)$, depending upon the ambient temperature.

Most of the steam used for district heating is prime steam from boilers. Less than $13 \%$ of the district heating steam is obtained from the exhaust of back pressure turhines. 15 However, some utiliites, Con Edison of New York 16 and Boston Edison, 17 for example, obtain as much as $50 \%$ of their steam from the exhaust of topping turb1nes.

Natural gas, oil, and coal are used about equally for boiler fuel. However, increasing fuel costs have resulted in consideration of using muncipal refuse incineration to supply district heating steam. The Nashville, Tenn. system ${ }^{18}$ has two large incinerator-boilers each capable of burning $0.4 \mathrm{~kg} / \mathrm{sec}$ ( 360 tons/day) of solid waste. This produces $27 \mathrm{~kg} / \mathrm{sec}(215,000 \mathrm{lb} / \mathrm{hr})$ of steam for heating and driving the turbines of two water chillers that provide a cooling capacity of $49 \mathrm{MJ} / \mathrm{sec}$ $(14,000$ tons $)$. Customers are supplied with $5^{\circ} \mathrm{C}\left(41^{\circ} \mathrm{F}\right)$ chilled water and $1034 \mathrm{kPa}$ (150 psi) steam for about 25-50\% below the previnus cost of operating their own systems. Another project ${ }^{19}$ at Saugus, Massachusetts will utilize $1.1 \mathrm{Gg}$ (1200 ton) of municipal refuse daily to provide more than half the annual energy needs of a nearby GE plant. Philadelphia Electric ${ }^{20}$ has signed a contract with the city to purchase steam from the city's incinerator while Baltimore Gas and Electric will buy steam from the city incinerator when it is installed. Other district heating companies, notably Boston Edison and Detroit Edison, will be interested in purchasing steam from the city if it decides to incinerate its municipal refuse.

The use of hot water distribution systems has found favor with the fastest growing sector of the district heating industry, namely colleges, universities and institutional developments (government complexes, shopping malls, etc.). However, these are generally new installations that do not require a change in equipment by the user. The prospects 
for changing existing steam distribution systems to hot water are not very promising. Not only would the switchover burden hundreds of customers with the cost of new equipment, but it would also require new mains to be installed or major modifications to the existing distribution system. A change to hot water would also burden users who need steam for air conditioning and other process uses. Therefore, even though hot water distribution is usually more economical (due in great part to lower maintenance costs) than steam systems, the economics of retrofitting might limit use to new installations in the U.S.

\section{Status of District Heating Outside the United States}

General background

District heating has found widespread acceptance in Europe and, to a lesser degree, in Japan and Canada. An indication of the popularity of district heating can be found in the industry growth statistics. The general rate of annual increase in district heating appears to be about $20 \%^{21}$ (in contrast to the average growth rate of $5 \%$ for U.S. systems). Since district heating has progressed furthest, and research is most actively being pursued in Europe, this discussion will concentrate on the status of European systems.

In many European countries heat is distributed in regions, towns, districts and villages to provide for space, water and process heating needs. In some instances the heat is also used to provide air conditioning by using absorption chillers. The heat source for these systems are generally oil-fired boilers or dual-purpose fossil fuel power plants.

The distribution networks generally consist of insulated steel pipes using hot water as the heat transmission fluid. Western European countries generally use a closed circuit system while Eastern European countries use some nonreturn systems. 22 Use of a hot water distribution network results in economic distribution over a larger distance than is typical for U.S. steam systems. Thus, European systems tend to have larger service areas than are typical for U.S. systems. Because of this they are able to serve areas of lower load density. For example, some Swedish systems serve some single family residences. 
The use of nuclear dual-purpose plants to supply heat to a district heating system has received attention in Europe, most notably in Sweden 23 and West Germany. ${ }^{7}$ France and Sweden are also studying the use of small swimming pool type reactors to supply low-temperature heat for urban use. 24 There have been several district heating systems that utilized small dual-purpose nuclear plants. The first was in Agesta, Sweden, which operated from 1964 to $1974 .{ }^{25}$ Heat from the Agesta BWR supplied $80 \mathrm{MW}$ of heat to Farsta, a suburb of Stockholm, and $10 \mathrm{MW}$ of electrical power using a back-pressure turbine. Because the economics of such a small scheme were not favorable, the plant was shut down just before the oil crisis of 1974.24 Another small nuclear dual-purpose plant is located at Bilibino in the Soviet Union. 25 This system consists of four individual plants. Each plant utilizes a PWR to deliver steam to a $12 \mathrm{MW}$ extraction-condensing turbine. The first plant has been in operation since 1973.

\section{European Systems}

An indication of the current status and projected future of district heating in Europe will be made by examining the systems of individual countries that have shown signiticant progress in district heating. Significant research, where appropriate, will also be indicated.

\section{$\underline{\text { USSR }}$}

The Soviet Union is the leader in dual-purpose heat and electric station installation. They operate over 1000 dual-purpose stations that supply heat to about 800 cities, industrial districts and population centers. 26 A majority of the installed heat and power stations are of relatively high capacity. In 1970 there were 169 dual-purpose plants with unit ratings of $100 \mathrm{MW}(\mathrm{e})$ or more. The average electrical rating for these plants was $208 \mathrm{MW}(\mathrm{e})$. Of these, 39 had ratings above $300 \mathrm{MW}(\mathrm{e})$. The five-year plan for $1971-75$ called for ratings of individual dualpurpose plants to exceed $1000 \mathrm{MW}(\mathrm{e})$.

The impact of dual-purpose installations in the Soviet Union can be realized by considering that in 1970 over $50 \%$ of the domestic heat demand 
was satisfied by heat from dual-purpose installations. ${ }^{7}$ These installations also represented $85 \%$ of the installed electrical generating capacity. 26

Dual-purpose stations supply a major ( $270 \%$ ) portion of the heat distributed in a centralized manner. The remainder is supplied by central fossil boilers. The total installed district heating capacity was sufficient to supply about $75 \%$ of the heating needs of cities and industrial. districts in 1970. Expected 1975 levels would increase the district heating contribution to about $80 \%$ of the domestic heat load.

$\underline{\text { Sweden }}$

In Sweden about $40 \%$ of the national energy use is for heating buildings. Currently, about $15 \%$ of that amount is supplied by district heating. 27 Most systems only serve the city centers and the more densely populated suburban areas. The district heating industry has been growing rapidly in recent years (the connected heat load has increased by a factor of 10 during the last 10 years), ${ }^{24}$ and some systems (notably the systems at Västeras and Linkoping) now serve single family residences. In two decades the Västeras system has grown rapidly so that it now supplies $98 \%$ of the residential heat demand. 24 The peak demand for this system is about 750 . MW. At the present time over $70 \%$ of Swedish urban areas are serviced by district heating systems. ${ }^{28}$

All of the larger Swedish systems (serving more than about 3000-4000 customers) utilize combined heat/electric power stations.22 These dualpurpose plants operate at a relatively high therma $\perp$ efficiency and con- . tribute to Euel conservation efforts. The Malmo dual-purpose plant, probably the most efficient, has achieved an operating thermal efficiency of $88 \% .22$

The major limitation to the wider introduction of district heating to single family residences is the cost of distributing the heat using current technology. 24 In an effort to alleviate this limitation, current research efforts are directed at demonstrating new pipe technologies for distribution temperatures of up to $100^{\circ} \mathrm{C}\left(212^{\circ} \mathrm{F}\right) .29$ Plastic lined concrete pipes and glass fiber armoured plastic pipes are being tested and evaluated for use in district healing dislribution systems. 
Considerations are also being given to district heating systems that would use nuclear dual-purpose plants as their heat source. Sydkraft, a private Malmö based utility serving the southern region of the country, has plans to use the Barsbäck 3 plant as a nuclear district heating plant. ${ }^{30}$ The turbine would be designed as an extraction system with steam bleeds in both the low- and high-pressure sections. This will result in a load following capability for both heat and electricity production. District heat would be supplied to Malmö and Lund first. At a later date Landskrona and Halsingborg would be added to the system. The total heat load of 1350 MW would be supplied by turbine bleed steam supplied by two reactors. The nuclear dual-purpose plant would be used for the thermal base load and would supply $80 \%$ of the area's heat needs but only $50 \%$ of the maximum demand. 29 The furthest distribution point in the system would be $41 \mathrm{~km}$ from the plant. The project is now stalled because of $a$ halt in construction of nuclear plants in Sweden. 30

\section{West Germany}

The demand for space heating in West Germany accounted for $40 \%$ of the total energy consumption during 1971.7 About 7 to $8 \%$ of the demand for space and water heating is met by district heating systems. In 1972 the total district heating supply was between 159,000-163,000 TJ (151154 TBCu), two-thirds coming from combined heat and power stations.

Recent West Germany studies ${ }^{7}$ concluded that district heating is not feasible for West German communities with less than 20,000 people. The study also concludes that $32 \%$ of the total heat demand for homes in West Germany could potentially be satisfied by district heating.

Another study ${ }^{7}$ concluded that a district heating system using a dual-purpose nuclear station would be economically competitive if the nuclear plant was located within $40 \mathrm{~km}$ ( 25 miles) of the city.

Plans are now being considered that would establish a national heating grid to supply heat to all towns with a population of 40,000 or more. The grid would supply about half of the energy needs of each city and would be augmented by central boilers in the city. 
Denmark

District heating in Denmark dates back 50 years. ${ }^{31}$ The greatest progress, however, has been made in the last 25 years and Denmark now leads the European league in terms of district heating per capita. In all about a third of its dwellings are supplied by a district heating network.

All district heating networks employ hot water transport and about 95\% of all customer installations are supplied directly from the network and with no intervening heat exchanger. In summer the sendout temperature is reduced to $65^{\circ} \mathrm{C}\left(149^{\circ} \mathrm{F}\right)$ to meet the water heating demand. The system is run at minimum temperature to maintain hot water service and to keep the insulation dry, reduce the piping stress range and to maintain relatively steady operating conditions for valves.

Distribution networks are clasified as linear or branched. The branched network is more reliable because two or more heat sources supply a given point. Shutdowns are, therefore, not as critical as in the linear system and extensions can be made readily. Branched systems also lend themselves to the addition of peak load stations.

Distribution systems currently use insulated pipes in a rectangular concrete duct filled with foamed concrete. Channels are provided at the base of the duct to drain any moisture to a sump. Future installations w1ll probably use pipe-1n-plpe techniques that have previously been used for consumer installations.

\section{Britain}

District heating progress in Britain has been slow because early failures gave the industry a reputation of being unreliable and because acceptance of a central home heat supply system has been recent. ${ }^{28}$ Two systems, however, deserve mention. The Pimlico, London system was completed in 1961 and serves 11,000 people. The exhaust steam from two turbines supply heat to the system. A hot water accumulator is used to balance the heat load and allow tull use of the distribution main from the power plant to the substation. 
The Nottingham system is the largest district heating system in Britain. With phased construction underway, it is expected that the total connected load will reach $129 \mathrm{MW}\left(440 \times 10^{6} \mathrm{Btu} / \mathrm{hr}\right)$ by 1980 . The expected total annual sale for the system is $1027 \mathrm{TJ}\left(9.75 \times 10^{11} \mathrm{Btu}\right)$. The primary heat source will be incinerated municipal refuse and heat will be supplied to the district heating system through the use of backpressure turbines.

Research is now being directed to the use of flexible plastic pipes in the distribution system. Use of such pipes significantly decrease installation costs since they are unwound from drums into slit trenches.

\section{Finland}

One-ha1f of the heat demand in Helsinki is met by district heating. ${ }^{7}$ The maximum output of the system is now $1280 \mathrm{MW}$ and is expected to rise to $3900 \mathrm{MW}$ in 1985. Present plans call for the increased load to be met via two nuclear plants, one which will be in service in 1984 and the other in 1990.

\section{Rumania}

The installed capacity of combined heat and power plants rose from $399 \mathrm{MW}$ in 1960 to $1978 \mathrm{MW}$ in $1969 .{ }^{7}$ Combined plants supplied $76 \%$ of the total heat delivered and $42 \%$ of the electriclty generated in the country.

\section{THERMAL ENERGY SUPPLY SYSTEM}

\section{Description of the Heat Supply System}

Several approaches for supplying thermal energy to the distribution grid were considered. All systems evaluated were multi-unit power stations with dual purpose operational capabilities. The alternate steam supply systems included: (1) pressurized water reactor (PWR),

(2) coal fired boiler, with stack gas sulfur removal, burning high sulfur coal, and (3) coal fired boiler burning low sulfur coal. Heat is supplied to the grid, from the power cycle, using an intermediate heat 
exchanger with appropriate amounts of prime and turbine bleed steam as shown in Figs: 2.1 and 2.2 .

All power station designs considered in this study had a nominal. total rated output of $2400 \mathrm{MW}(\mathrm{e})$. The nuclear stations consisted of two units, each with a $1200 \mathrm{MW}(\mathrm{e})$ rating, while the coal stations were composed of three $800 \mathrm{MW}(\mathrm{e})$ units. For the base case design one unit is operated in a dual purpose mode, producing electricity and supplying heat to the thermal grid, while the other units produce only electricity. To insure a reliable source of heat the piping system is, designed to supply heat to the grid from all units in the power station.

\section{PWR system}

The reactor station consists of two current type $3750 \mathrm{MW}(t)$ pressurized water reactors and a power conversion system. The nuclear steam supply system is made up of closed loops that transport heat from the reactor core to the steam generators by circulating pressurized water. The system basically consists of a reactor pressure vessel containing the reactor core, the steam generator, pumps for circulating the pressurized water, and a pressurizer that matntains and controls system pressure. A typical PWR coolant system schematic is illustrated in Fig. 4.1 and characteristics representative of a PWR nuclear steam station are given in Table 4.1.

The reactor core is cooled by demineralized water that enters the side of the vessel, flows through the core, and out to the steam generators. The water then goes to the main circulating pumps and back to the reactor vessel in a closed loop. The primary coolant must be pressurized sufficiently to prevent boiling. This is accomplished by an electrically heated pressurizer in the system.

The containment structure, illustrated in Fig. 4.2, completely encloses the reactor and reactor coolant system to ensure that essentially no leakage of radioactive material to the environment would result in the event of a gross failure of the reactor coolant system. The structure also provides biological shielding for normal accident conditions and is designed to maintain its integrity under tornado wind loading and other natural forces. The containment building is a concrete structure 


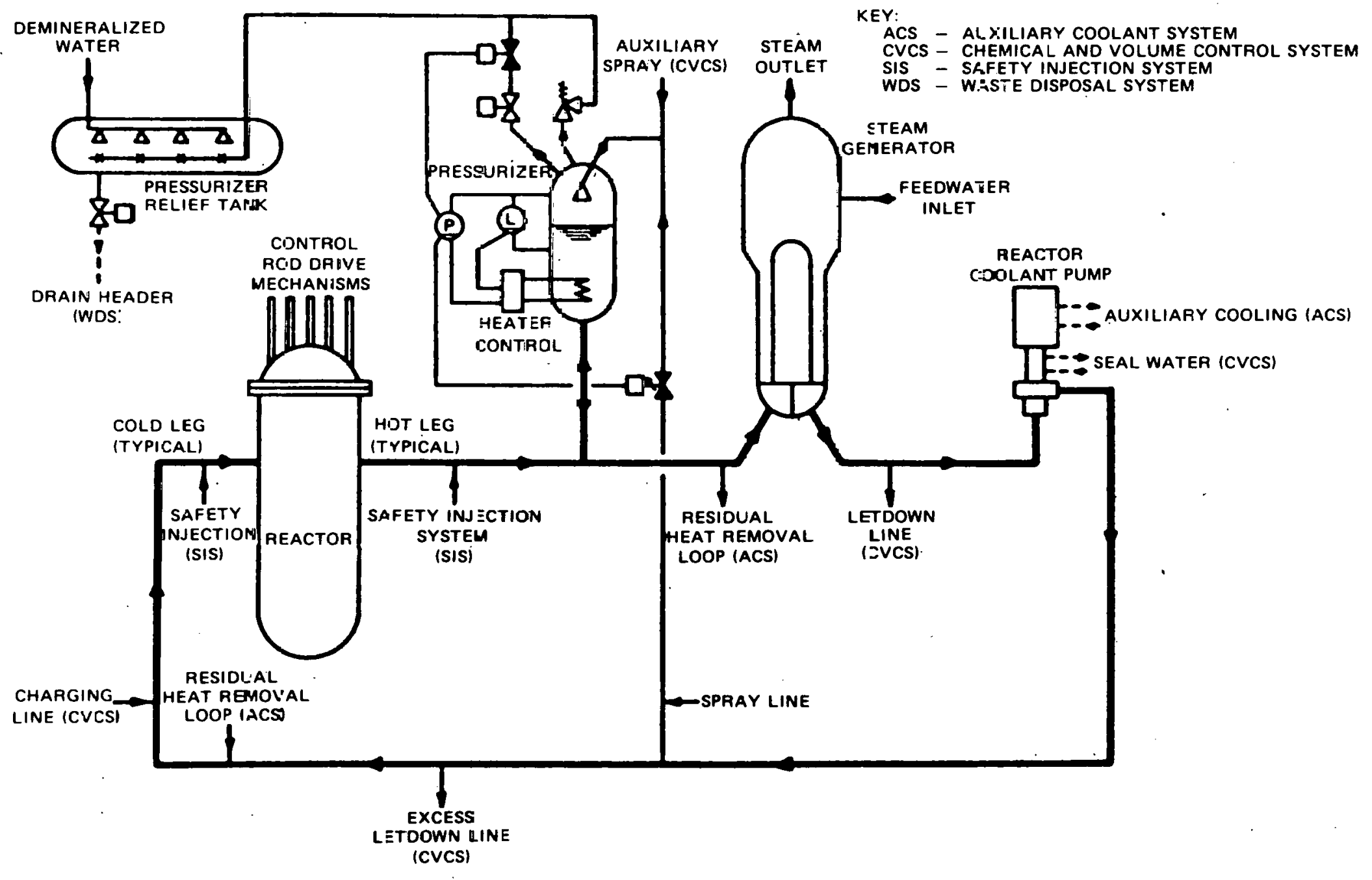

Fig. 4.1. Typical PWR reactor coolant system. 
Table 4.1. Design characteristics [3750 MW(t) PWR]

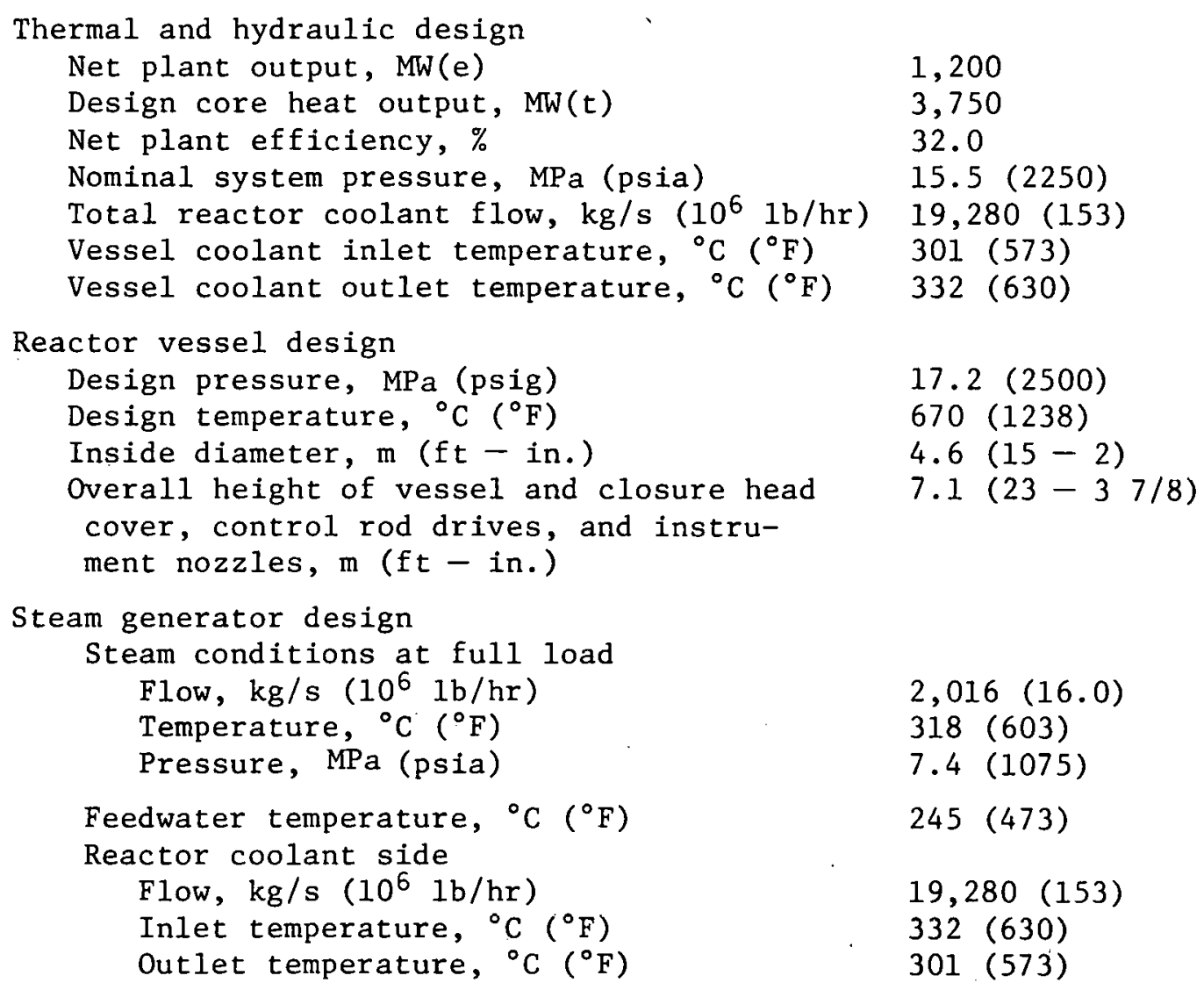

with a steel liner to ensure leak tightness. Steam lines penetrate the containment and convey the steam to the turbine building and the thermal grid heat exchanger.

The reactor is refueled by removing the pressure vessel head and flooding the volume above the core. Underwater handling of the fuel and other reactor components is then possible. Fuel loading of a large PWR core is generally based nn a three year cycle. Approximately one third of the core is replaced annually. The mimimum downtime required for depressurization, cooldown, refueling, repressurization and startup is about 10 days.

The turbine-generator system is subject to some variation, partly due to the amount of steam supplied to the heat exchangers for supply of heat to the thermal grid. For the base case, all the steam from one 
ORNL-OWG 74-5674R

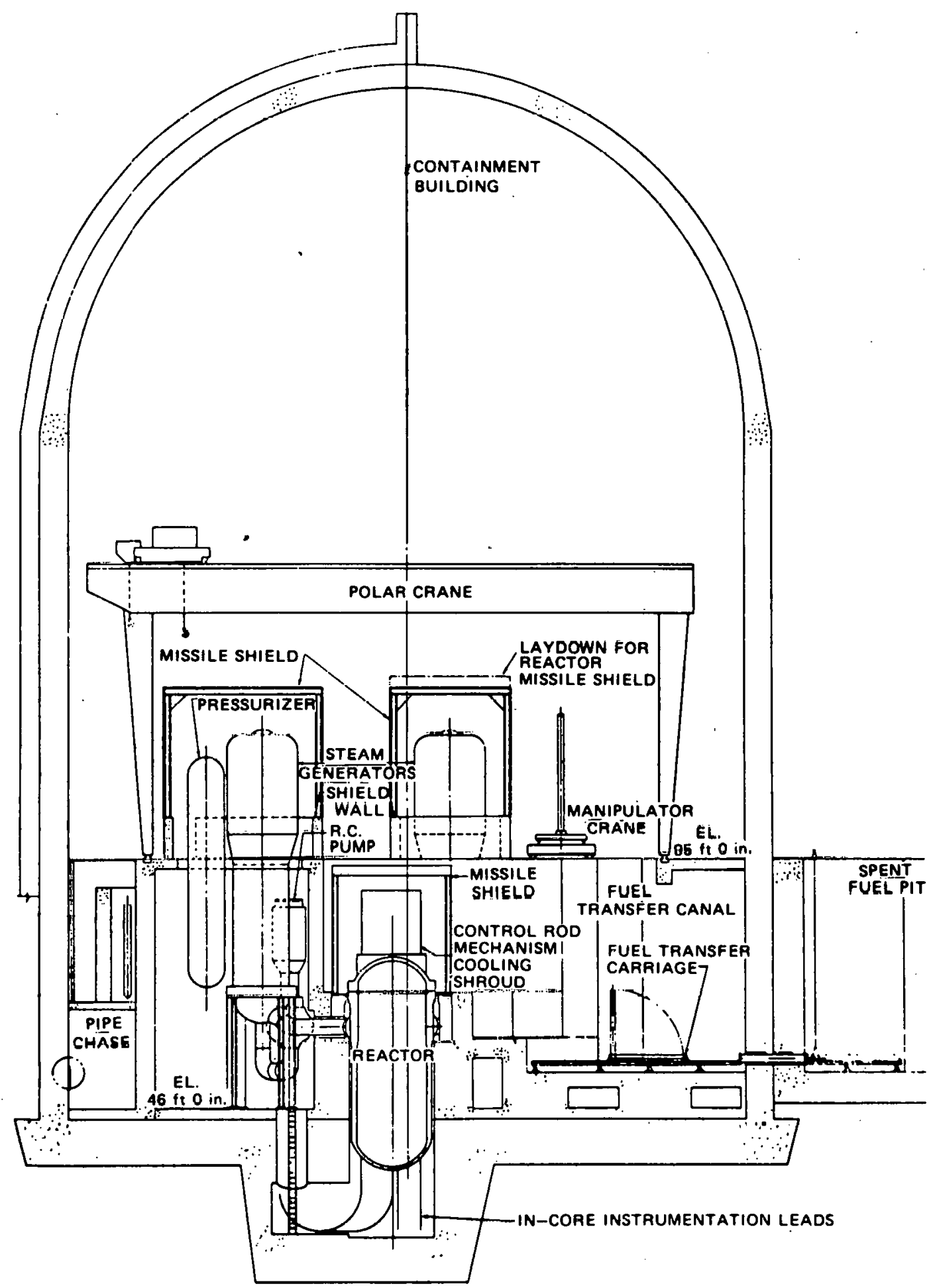

Fig. 4.2. Typical PWR containment. 
reactor is supplied to a $1200 \mathrm{MW}(\mathrm{e})$ turbogenerator while steam from the second reactor is split $85 / 15$ between a $1020 \mathrm{MW}(\mathrm{e})$ turbogenerator and the thermal grid heat exchanger which is capable of producing $252 \mathrm{~kg} / \mathrm{s}$ $\left(2 \times 10^{6} \mathrm{bb} / \mathrm{hr}\right)$ of steam at $274^{\circ} \mathrm{C}\left(525^{\circ} \mathrm{F}\right)$ and $5861 \mathrm{kPa}(850 \mathrm{psia})$ using prime reactor steam. The capacity of the heat exchanger and the smaller turbogenerator can, of course, be varied to match site specific thermal requirements. For applications requiring lower temperatures the smaller generator can be driven by an extraction or back pressure turbine with the extraction or exhaust steam used to supply heat to the thermal grid at the required temperature.

The $1200 \mathrm{MW}(\mathrm{e})$ turbine generator includes an $1800 \mathrm{rpm}$ turbine with one high pressure and three low pressure sections. Combination moisture separator-reheaters are provided to dry and superheat the steam between the high and low pressure turbine sections.

The second turbogenerator uses the same steam cycle as the 1200 MW(e) unit for the base case. However, if an extraction or back pressure turbine is required, a pressure reducing station is needed to provide low-pressure steam to the heat exchangers when this turbine is shut down for maintenance.

\section{Coal systems}

The steam supply station consists of three $2192 \mathrm{MW}(t)$ coal fired boilers and the required power conversion equipment. The general design characteristics outlined in Table 4.2 are applicable for both the low and high sulfur coal burning plants.

Low sulfur eastern and western coals can be used to fire steam boilers with no special stack-gas cleaning, since sulfur dioxide $\left(\mathrm{SO}_{2}\right)$ emissions generally are within the Environmental Protection Agency (EPA) standard of $0.54 \mathrm{~kg}(1.2 \mathrm{lb})$ per $1.055 \mathrm{GJ}\left(10^{6} \mathrm{Btu}\right)$ of heat input. However, particulate removal equipment, usually an electrostatic precipitator, will be required to meet the EPA standard of $43 \mathrm{~g} / \mathrm{GJ}$ (U. $\left.\mathrm{L} \mathrm{Lb} / \mathrm{LU} \mathrm{U}^{\epsilon} \mathrm{Btu}\right)$.

These large boilers are generally fired with pulverized coal. The boiler plant, therefore, includes the necessary coal and ash storage and handling facilities. Since western coals generally have a higher ash content (some as high as $20 \%$ by weight) than eastern coals (typically 
Table 4.2. Design characteristics $800 \mathrm{MW}(\mathrm{e})$ coal fired plant

\begin{tabular}{ll}
\hline General & \\
Net plant output, MW(e) & 800 \\
Net coal boiler output, MW(t) & 2192 \\
Net plant efficiency, $\%$ & 36.5 \\
Steam generator design & \\
Steam conditions at full 1oad & \\
Flow, kg/s ( $\left.10^{6} \mathrm{lb} / \mathrm{hr}\right)$ & $665(5.28)$ \\
Temperature, ${ }^{\circ} \mathrm{C}\left({ }^{\circ} \mathrm{F}\right)$ & $538(1000)$ \\
Pressure, kPa (psia) & $4279(621)$ \\
Feedwater temperature, ${ }^{\circ} \mathrm{C}\left({ }^{\circ} \mathrm{F}\right)$ & $260(500)$ \\
\hline
\end{tabular}

4 to $8 \%$ by weight), ash handling equipment must be sized to handle a larger volume. Additionally, western coals generally have a higher moisture content, 12 to $37 \%$ on a weight basis (eastern coals are 1 to $6 \%$ ), and have a lower energy content $[19,125 \mathrm{~J} / \mathrm{g}(8500 \mathrm{Btu} / 1 \mathrm{~b})]$ than eastern coals $[25,875-32,625 \mathrm{~J} / \mathrm{g}(11,500-14,500 \mathrm{Btu} / 1 \mathrm{~b})]$. Therefore, the type of coal used will influence the design and slze of the boiler equipment.

EPA standards for new fossil-fuel-fired steam generators essentially require sulfur removal for coals containing more than about $0.7 \%$ sulfur. Removal of the sulfur can occur either from the coal before burning or from the stack gas.

The sulfur removal method assumed for this study utilizes a 11mestone slurry process to scrub the stack gas. In this process, the flue gas is scrubbed with a 5 to $15 \%$ slurry of calcium sulfite/sulfate containing small amounts of continuously added limestone. The solids are continuously separated from the slurry and usually disposed of in a settling pool.

For the coal system base case all the steam from two of the boiler plants is delivered to two $800 \mathrm{MW}(\mathrm{e})$ turbogenerators. Steam from the third boiler is split $63 / 37$ between a $500 \mathrm{MW}(\mathrm{e})$ turbine-generator set and the thermal grid. Prime steam directed to the thermal grid supplies $252 \mathrm{~kg} / \mathrm{s}\left(2 \times 10^{6} \mathrm{ib} / \mathrm{hr}\right)$ of steam at $538^{\circ} \mathrm{C}\left(1000^{\circ} \mathrm{F}\right)$. Since the base case assumes a steam transport system for the thermal grid, an intermediate heat exchanger is not required. (In actual practice a heat exchanger would probably be required. The alternative is to use a condensate 
cleanup system or not return the thermal grid condensate and use makeup water.) Prime steam or turbine extraction steam can be utilized by the grid directly from the boiler or turbine. However, for any other transport fluid (e.g., water, ammonia, etc.) an intermediate heat exchanger would be required. As discussed previously, the design of the turbinegenerator system and the thermal grid heat exchanger is subject to variations and can be altered to meet other design requirements if necessary.

The $800 \mathrm{MW}(\mathrm{e})$ turbine generator includes a $3600 \mathrm{rpm}$ turbine with one high pressure, one intermediate pressure and three low pressure sections. A combination moisture separator-reheater is provided to dry and superheat the steam between the high and intermediate pressure sections.

The smaller turbogenerator uses the same steam cycle as the $800 \mathrm{MW}(\mathrm{e})$ unit for the base case. If an extraction or back pressure turbine is required, a pressure reducing station will also be required to provide low-pressure steam to the thermal grid when the turbine is shut down for maintenance.

Description of the intermediate heat exchanger

The intermediate heat exchanger serves several functions. It allows alternate heat' transport fluids to be considered for the thermal grid transmission system and provides a further barrier to minimize the possibility of radioactive contamination of the distributed heat. ${ }^{*}$ Additionally, it prevents poor quality water from leaking into the boller feed water. Although the base case applications assume steam transport lines, other heat transport fluids (e.g., ammonia, oils, and heat transfer salts) can be used. The heat exchanger is then used in these applications to transfer heat from the power cycle steam to these fluids.

For the base case systems using a nuclear heat supply it is desirable to provide an additional barrier between the reactor coolant (primary system) and the thermal grid steam (tertiary system). Although primary

\footnotetext{
*Note: If the water or heat transfer fluid is pressurized above steam pressure in the heat exchanger, then leakage into the thermal grid is implausible. This situation is similar to that in power plant condensers.
} 
to secondary (power cycle steam) leakage is not expected, the possible contamination of the secondary system is not excluded as a conservative design consideration. To prevent any possible radioactive carryover to the thermal grid, the tertiary loop (thermal grid system) utilizes a steam evaporator (also called a reboiler) to transfer heat from the secondary system.

The major components of the heat exchanger system include a set of reboilers and a feedwater heater. The rebollers are U-tube and shell heat exchangers with prime secondary steam from the PWR at about $317^{\circ} \mathrm{C}$ $\left(603^{\circ} \mathrm{F}\right)$ and $7407 \mathrm{kPa}$ (1075 psia) being supplied to the tube side of the reboiler. Steam for thermal grid distribution is generaced at $274^{\circ} \mathrm{C}$ $\left(525^{\circ} \mathrm{F}\right)$ and $5857 \mathrm{kPa}(850 \mathrm{psia})$ on the shell side. For the base case $252 \mathrm{~kg} / \mathrm{sec}$ ( 2 million pounds per hour) of steam is generated in several high-pressure reboiler units of about $63 \mathrm{~kg} / \mathrm{sec}(500,000$ pounds per hour) capacity each. One backup unit is provided to maintain full steam flow during reboiler maintenance. If a lower pressure and temperature are required by the thermal grid, steam (or any of the other possible heat transfer fluids) can be supplied using low-pressure reboilers that are heated with turbine extraction steam or. with exhaust from a back-pressure turbine. The feedwater heater associated with the reboilers is used to preheat the fluid returning from the thermal grid system before it is returned to the reboilers.

It is assumed that condensate from the reboiler is returned to the boiler feed stream at $121^{\circ} \mathrm{C}\left(250^{\circ} \mathrm{F}\right)$ and $344.5 \mathrm{kPa}(50 \mathrm{psia})$. It is further assumed that the condensate would require only minor treatment to meet reboiler water quality requirements.

\section{Economic Analysis}

To provide a unitorm basis for comparison, costs were estimated for supplying heat to the thermal grid with each of the energy systems considered. The capital costs for nuclear and coal steam electric and process steam plants were estimated in accordance with the economic ground rules shown in Table 4.3. These costs were estimated with an updated version of the CONCEPT ${ }^{32}$ code and are based on a multiple unit station. Interest during construction is included and escalation beyond mid-1976 
Table 4.3. Economic ground rules for estimating capital costs and nonfuel O\&M costs for conventional plants

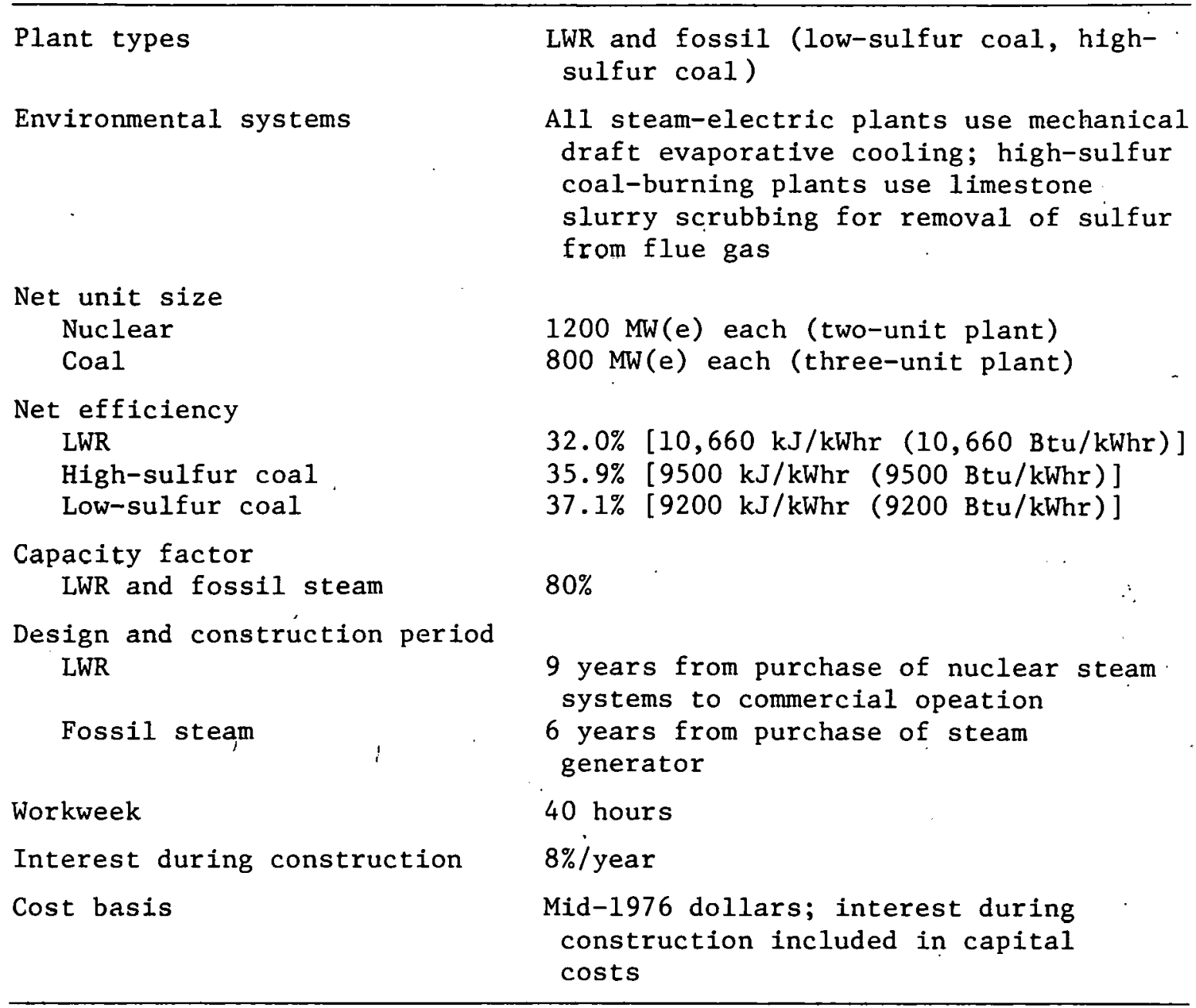

is not accounted for. The cost for the turbine plant is assumed to be directly proportional to the gross electrical output.

$\underline{\text { Production costs for PWR system }}$

Table 4.4 summarizes the levelized production costs for a two-unit dual-purpose reactor station in base-case configuration. The nonfuel operating and maintenance costs were estimated using the $\mathrm{OMCOST}^{33}$ computer code. The reboiler plant O\&M costs were obtained by appropriate modification of the turbine plant estimates. These costs are given in mid1976 dollors. 
Table 4.4. Levelized production costs for

$3750 \mathrm{MW}(\mathrm{t})$ PWR base case

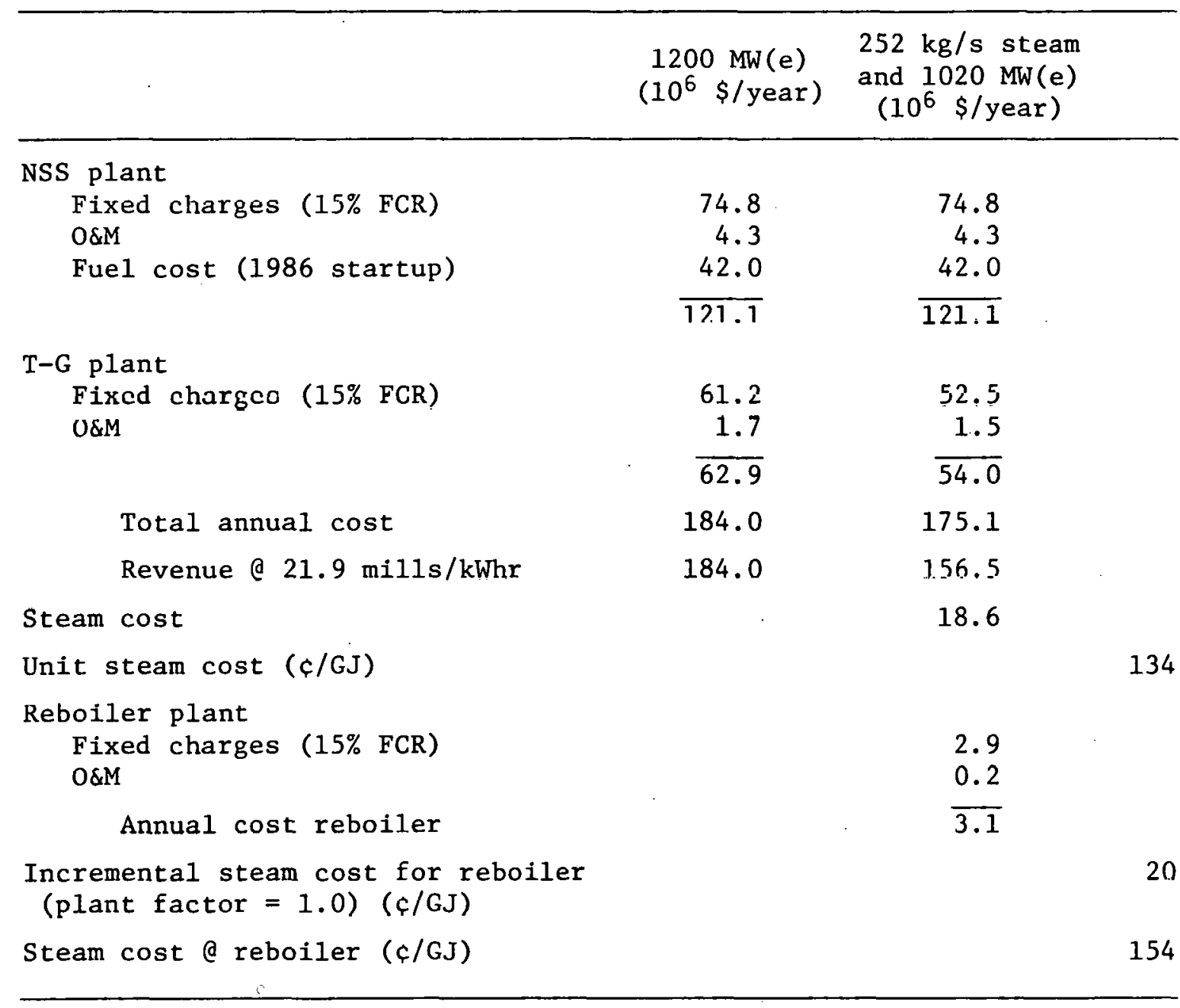

I'he fuel cycle costs were adapted from Ref. 34 for 1986 plant startup in terms of mid 1976 dollars. With a plant factor of 0.8 , the annual expense for fuel amounts to 42 million dollars per unit corresponding to a fuel charge of $47 \mathrm{c} / \mathrm{GJ}\left(47 \mathrm{c} / 10^{6} \mathrm{Btu}\right) . *$

The required revenue from process steam was calculated by taking the difference between the annual cost and the annual revenue from the sale of electricity. The total annual production cost for the $1200 \mathrm{MW}(\mathrm{e})$ unit is 184 million dollars. Since this value is not affected by the

\footnotetext{
${ }^{*}$ For the purpose of this report, $1 \times 10^{6} \mathrm{Btu}$ will be equated to $1 \mathrm{GJ}$. The actual conversion is $1.055 \mathrm{GJ}$.
} 
dual purpose nature of the station, it was considered a fair price for computing the revenue obtained from the sale of electricity. This income amounts to $\$ 156.5$ million per year for the $1020 \mathrm{MW}(\mathrm{e})$ unit leaving $\$ 18.6$ million to be obtained from the sale of $1.39 \times 10^{7} \mathrm{GJ} /$ year $\left(1.39 \times 10^{13}\right.$ Btu/year) of heat supplied to the grid. This is equivalent to a cost of $134 \mathrm{c} / \mathrm{GJ}\left(134 \mathrm{c} / 10^{6} \mathrm{Btu}\right)$ for reactor prime steam when used as the thermal grid heat source.

The reboiler plant costs were derived from preliminary data obtained for the Midland Station.* Investment capital was estimated to be directly proportional to the process steam flow rate amounting roughly to $\$ 75,400$ per $\mathrm{kg} / \mathrm{s}$ ( 9.5 dollars per pound per hour). This essentiaily adds $20 \mathrm{c} / \mathrm{GJ}$ $\left(20 \mathrm{c} / 10^{6} \mathrm{Btu}\right)$ to the cost of heat supplied to the grid. Therefore, the net heat cost, using PWR prime steam is $154 \mathrm{c} / \mathrm{GJ}\left(154 \mathrm{c} / 10^{6} \mathrm{Btu}\right)$ at the reboiler.

Production costs for low sulfur coal system

Table 4.5 summarizes the levelized production costs for a threeunit dual purpose coal station that uses low sulfur coal for fuel. Because the base case configuration assumes steam transport in the thermal grid, the reboiler plant was omitted in Table 4.5. As previously mentioned, a reboiler would probably be required in actual practice. Since a reboiler is included in the design when alternate heat transport fluids are considered, it was felt that for the purposes of this report it would be of interest to examine the impact of the reboiler costs. Therefore, the steam base case was evaluated without the reboiler.

The typical price for low sulfur western coal is about $\$ 5.51 /$ metric ton $\left(\$ 5 /\right.$ ton) at the mine mouth. ${ }^{34}$. Assuming the coal is shipped $2400 \mathrm{~km}$ (1500 miles) to the point of use raises the coal cost to $\$ 17.90 /$ metric ton (\$16.25/ton). This corresponds to a fuel charge of $96 \mathrm{c} / \mathrm{GJ}$ ( $\left.96 \mathrm{c} / 10^{6} \mathrm{Btu}\right)$. Therefore, the annual fuel cost for a single $800 \mathrm{MW}(e)$ unit is $\$ 49.5$ million.

* The Midland Station is being designed by Consumer Power Corp. to produce power and supply steam to a nearby Dow chemical facility. 
Table 4.5. Levellzed production costs for $2156 \mathrm{MW}(t)$

low sulfur coal base case

\begin{tabular}{|c|c|c|c|}
\hline & $\begin{array}{l}1600 \mathrm{MW}(\mathrm{e})- \\
2 \text { units } \\
\left(10^{6} \text { \$/year }\right)\end{array}$ & $\begin{array}{l}252 \mathrm{~kg} / \mathrm{s} \text { steam } \\
\text { and } 500 \mathrm{MW}(\mathrm{e}) \\
\left(10^{6} \$ / \text { year }\right)\end{array}$ & \\
\hline $\begin{array}{l}\text { SS plant } \\
\text { Fixed charges (15\% FCR) } \\
\text { O\&M } \\
\text { Fuel cost }\end{array}$ & $\begin{array}{r}56.3 \\
7.5 \\
99.0 \\
162.8\end{array}$ & $\begin{array}{r}28.2 \\
3.8 \\
49.5 \\
01.5\end{array}$ & \\
\hline $\begin{array}{l}\text { T-G plant } \\
\text { Fixcd chargco (15\% FCP) } \\
\text { O\&M }\end{array}$ & $\begin{array}{r}63.5 \\
2.9 \\
66.4\end{array}$ & $\begin{array}{r}14.1 \\
0.9 \\
20.6\end{array}$ & . \\
\hline Annual cost & 229.2 & 102.1 & \\
\hline Revenue @ $20.4 \mathrm{mills} / \mathrm{kWhr}$ & 229.2 & 71.5 & \\
\hline Steam cost & & 30.6 & \\
\hline Unit steam cost $\left(c / 10^{6} \mathrm{Btu}\right)$ & & & 177 \\
\hline
\end{tabular}

The required revenue from process steam was again calculated using the difference between the annual cost and the annual revenue from the sale of electricity. The total annual production cost for two of the 800 MW(e) units is 229.2 million dollars. S1nce this value is not affected by the dual purpose nature of the third unit, it was used to compute the revenue obtained from electricity sale. The income derived from the sale of electricity is 71.5 million dollars for the 936 MW(e) unit leaving $\$ 30.6$ million to be obtained from the sale of $1.74 \times 10^{7} \mathrm{GJ} /$ year $\left(1.74 \times 10^{13} \mathrm{Btu} /\right.$ year $)$ of thermal grid heat. Thus, the cost for $538^{\circ} \mathrm{C}\left(1000^{\circ} \mathrm{F}\right), 4272 \mathrm{kPa}(620 \mathrm{psia})$ steam to the grid is $177 \mathrm{c} / \mathrm{GJ}$ $\left(177 \mathrm{c} / 10^{6} \mathrm{Btu}\right)$.

As expected, an examination of the relationship of steam cost and fuel price indicated a direct dependence. When the cost of low sulfur coal was raised from $96 \mathrm{c} / \mathrm{GJ}\left(96 \mathrm{c} / 10^{6} \mathrm{Btu}\right)$ to $106 \mathrm{c} / \mathrm{GJ}\left(106 \mathrm{c} / 10^{6} \mathrm{Btu}\right)$, the steam cost rose from $177 \mathrm{c} / \mathrm{GJ}\left(177 \mathrm{c} / 10^{6} \mathrm{Btu}\right)$ to $187 \mathrm{c} / \mathrm{GJ}\left(187 \mathrm{c} / 10^{6} \mathrm{Btu}\right)$. Thus, although the relative increases (10\% increase in fuel cost and 
$5.6 \%$ increase in steam price) differed, the actual rise in cost [10c/GJ $\left.\left(10 \mathrm{c} / 10^{6} \mathrm{Btu}\right)\right]$ was the same for both costs.

Production costs for high sulfur coal system

Table 4.6 summarizes the levelized production costs for a coal station, in base-case configuration, burning high sulfur coal. 'It is evident that the steam plant fixed charges are larger for the high sulful coal plant than for the low sulfur case. Several major differences. in the plant designs contribute to this cost difference. Because of the high ash and moisture content of western low sulfur coals, the boiler and ash handling equipment is sized larger than for an equivalent heat output using eastern coals. This cost difference, however, is overshadowed by the need for stack gas scrubbing equipment for plants burning high sulfur coal.

Table 4.6. Levelized production costs for $2228 \mathrm{MW}(t)$ high sulfur coal base case

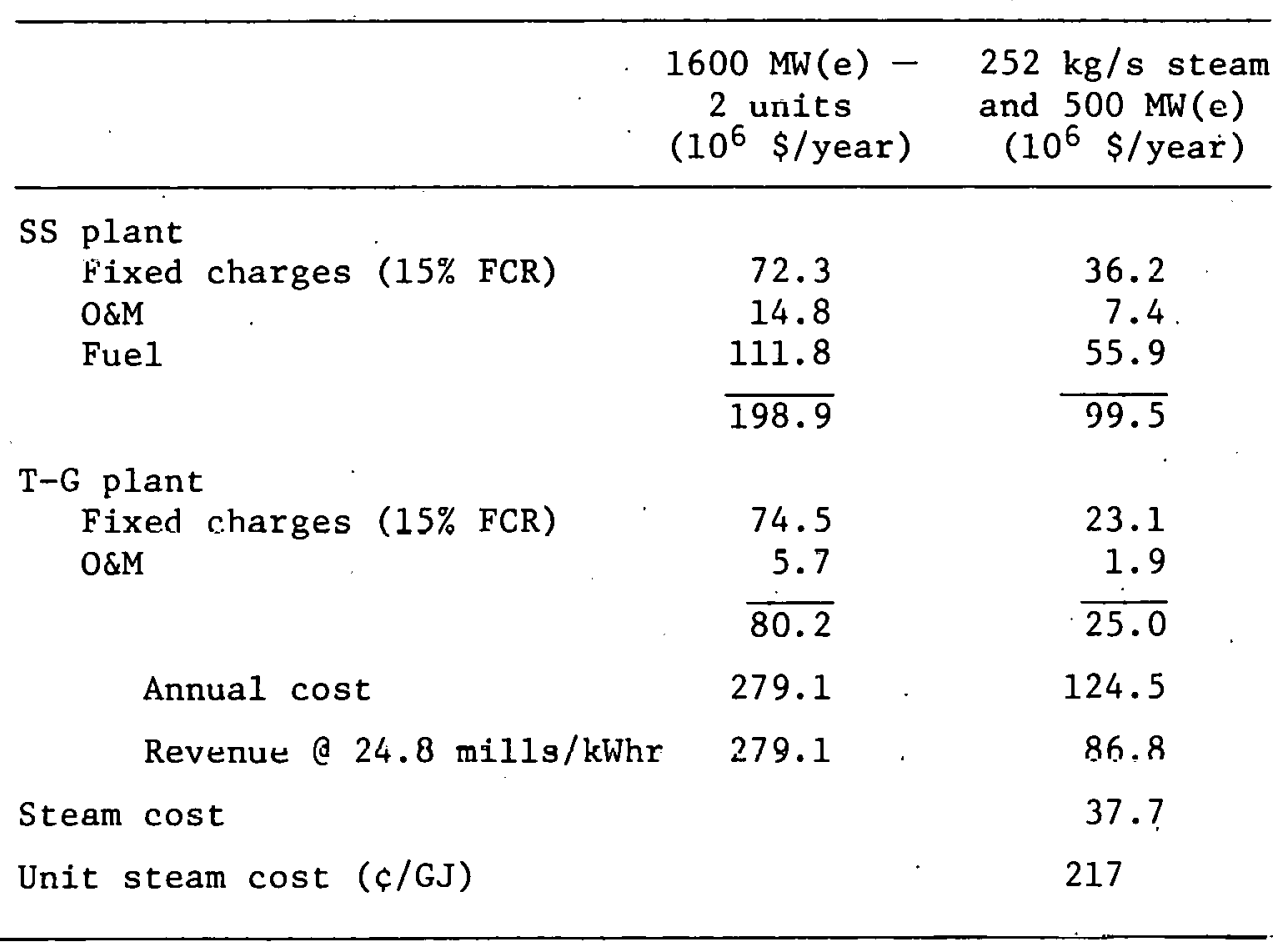


The typical price for high sulfur eastern coal is about $\$ 27.5 /$ metric ton ( $\$ 25 /$ ton) which corresponds to a fuel charge of $\$ 1.05 / \mathrm{GJ}\left(\$ 1.05 / 10^{6}\right.$ $B t u)$. The annual fuel charge for a single $800 \mathrm{MW}(e)$ unit, therefore, amounts to $\$ 55.9$ million.

Since a reboiler plant is not required for the base case configuration, the cost of heat to the thermal grid is equal to the production costs. Thus, for a high sulfur coal plant $1.74 \times 10^{7} \mathrm{GJ} /$ year $\left(174 \times 10^{13}\right.$ $\mathrm{Btu} /$ year) of steam at $538^{\circ} \mathrm{C}\left(1000^{\circ} \mathrm{F}\right)$ and $4277 \mathrm{kPa}(620 \mathrm{psia})$ will cost $217 \mathrm{c} / \mathrm{GJ}\left(217 \mathrm{c} / 10^{6} \mathrm{Btu}\right)$.

\section{Cost of Supplying Hcat to the Thermal Grid}

The cost of supplying heat to the thermal grid at various temperatures was calculated using Fig. 4.3 and the unit steam costs evaluated in Tables 4.4-4.6. Figure 4.3 was derived by modifying cost data presented in Ref. 35 for dual purpose LWRs. This curve relates the cost of steam (C) at any desired temperature $(\mathrm{T})$ to the cost of steam $\left(\mathrm{C}_{0}\right)$ at the maximum available temperature $\left(\mathrm{T}_{0}\right)$. Although these values are to be considered approximate for the coal-fired station case, they are adequate for the preliminary cost estimates required in this report.

Table 4.7 summarizes the cost of supplying heat to the thermal grid at various temperatures using various fluids to transport the energy over long distances. For temperatures lower than those provided by prime steam, turbine extraction steam or back pressure steam is used to heat the thermal grid fluid.

The coal systems feeding a thermal grid that uses steam as the transport medium shows a significant cost reduction because a reboiler plant is not required. When alternate heat transport media are used (water, oils, etc.), a reboiler system is rernired. The reboiler plant costs for the coal unit were assumed to be similar to that for the nuclear case.

Although the heat costs in Table 4.7 were calculated on the basis of supplying $252 \mathrm{~kg} / \mathrm{s}\left(2 \times 10^{6} \mathrm{lb} / \mathrm{hr}\right)$ of steam to the thermal $\mathrm{grid}$, they are valid for somewhat larger or smaller flows. 


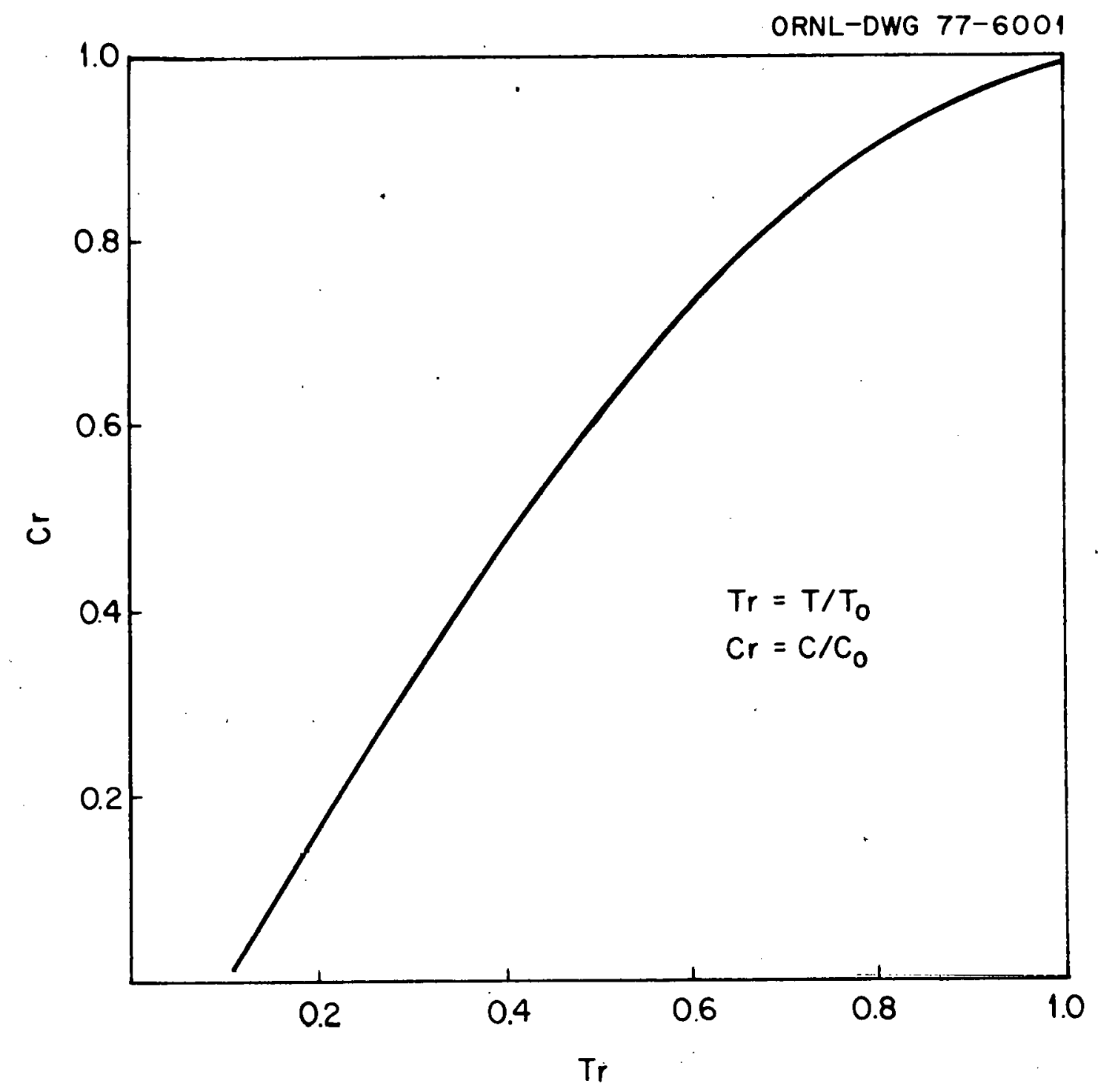

Fig. 4.3. Unit steam cost as a function of temperature for LWR system. 
Table 4.7. Sumary of thermal energy supply costs

\begin{tabular}{|c|c|c|c|c|c|c|}
\hline \multirow[b]{2}{*}{ Steam supply system } & \multirow{2}{*}{$\begin{array}{c}\text { Thermal grid } \\
\text { heat transport } \\
\text { medium }\end{array}$} & \multirow{2}{*}{$\begin{array}{c}\text { Maximum grid } \\
\text { supply temperature } \\
\left({ }^{\circ} \mathrm{C}\right)\end{array}$} & \multicolumn{4}{|c|}{ Heat cost $(c / G J)$} \\
\hline & & & $\begin{array}{c}\text { Maximum } \\
\text { temperature }\end{array}$ & $250^{\circ} \mathrm{C}$ & $200^{\circ} \mathrm{C}$ & $150^{\circ} \mathrm{C}$ \\
\hline PWR & $\begin{array}{l}\mathrm{A}_{-}^{-} 1 \text { fluics } \\
\text { considered } a\end{array}$ & 274 & 154 & 149 & 132 & 103 \\
\hline High sulfur coal & Steam & 538 & 217 & 124 & 91 & 65 \\
\hline Low sulfur coal & Steam & 538 & 177 & 100 & 74 & 53 \\
\hline High sulfur coal & Ail others & 538 & 235 & 142 & 109 & 83 \\
\hline Low sulfur coal & A $\underline{1} 1$ others & 538 & 194 & 118 & 92 & 71 \\
\hline
\end{tabular}

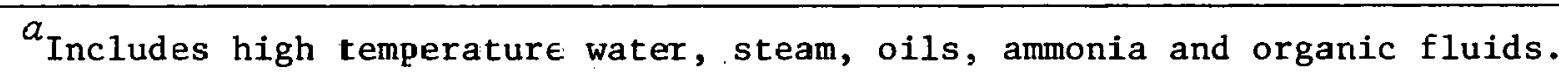




\section{. V. THERMAL ENERGY CONVEYANCE}

Thermal energy conveyance within the thermal grid has been divided into two categories: long distance transmission and distribution within the consuming subregion. The long range transmission system delivers heat from the dual purpose power station to substations that provide heat to the regions served by the thermal grid. The substation essentially consists of a heat exchanger which transfers heat from the long distance transmission system to the subregion distribution network. If the heat transport fluid is the same for both delivery systems, the heat exchanger can be replaced by a regulator and piping to divert an appropriate portion of the transport fluid to the subregion.

The subregion distribution network delivers heat from the regional substation to the property line of the consumer. Connections are provided at the consumer's property line to enable customers to utilize heat from the grid.

\section{Long Distance Transmission}

Both liquid and vapor phase technologies were initially considered for the long distance heat transmission medium. High temperature water, organic fluids, and molten salts were the liquid phase candidates considered, while steam and ammonia were considered for the vapor phase transport systems. A cursory investigation of these substances revealed safety or environmental problems associated with some of the technologies which eliminated them from further consideration.

\section{Liquid phase transmission}

The organic fluid appeared to be especially troublesome from an environmental standpoint. Many of the organics on the market possess a flashing potential. Therefore, there exists a potential fire hazard that must be accounted for in the design. In the past, fire resistant organic fluids were available on the market. However, many of them were chlorinated biphenyles which have now been banned from the market because of environmental problems. Because of these considerations, the use of 
organic fluids in the thermal grid did not appear to be attractive and was not considered further.

The molten salt system has the potential to transport high temperature energy. However, the freezing point for many of the salt mixtures is on the order of $149^{\circ} \mathrm{C}\left(300^{\circ} \mathrm{F}\right)$. Additionally, at temperatures near the freezing point the molten salt system requires five times the pumping power required by a water transport system to transport a given amount of heat. Since much of the heating load serviced by the thermal grid will utilize heat at about $177^{\circ} \mathrm{C}\left(350^{\circ} \mathrm{F}\right)$ or lower, the molten salt system did not appear feasible for this application and was not rnnsidered further in this study.

It therefore appeared that the most promising liquid phase technology for the long distance transport system was a high temperature water system. The economics for this system were estimated for both high $\left[260^{\circ} \mathrm{C}\right.$ $\left.\left(500^{\circ} \mathrm{F}\right)\right]$ and lower $\left[177^{\circ} \mathrm{C}\left(350^{\circ} \mathrm{F}\right)\right]$ temperature heat.

\section{Liquid phase transmission economics}

As an economic baseline the cost to deliver $2000 \mathrm{MW}(t)$ of water at $260^{\circ} \mathrm{C}\left(500^{\circ} \mathrm{F}\right)$ was estimated. For the purposes of this study a $111^{\circ} \mathrm{C}$ $\left(200^{\circ} \mathrm{F}\right)$ temperature drop at the transmission line terminal end was assumed. A thermal grid of this size would be capable of supplying about $630 \mathrm{~kg} / \mathrm{sec}\left(5 \times 10^{6} \mathrm{lb} / \mathrm{hr}\right)$ of steam to industry and satisfy about $40 \%$ of the commercial-residential heat demand for a city the size of Philadelphia. Table 5.1 summarizes the capital costs for a $48 \mathrm{~km}$ ( 30 miles) steel pipeline delivering $2000 \mathrm{MW}(t)$.

The transmission system design was based on a water velocity of $6.1 \mathrm{~m} / \mathrm{sec}(20 \mathrm{ft} / \mathrm{sec})$. It therefore required five $1.22 \mathrm{~m}$ (48 in.) pipelines to transport the design heat load. Return pipelines have been included in the estimate. Based on this design pumping power requirements are $27 \mathrm{MW}(\mathrm{e})$.

Heat loss from the pipeline is approximately $1^{\circ} \mathrm{C}\left(2^{\circ} \mathrm{F}\right)$ for every $16 \mathrm{~km}$ (10 miles).

Based on the capital cost estimates in Table 5.1 the unit transportation costs were estimated. Assuming electrical power costs of 
Table 5.1. Capital cost estimate for a $48 \mathrm{~km}$ hot water pipeline delivering $2000 \mathrm{MW}(\mathrm{t})$ at $260^{\circ} \mathrm{C}$

\begin{tabular}{|c|c|}
\hline Item & $\begin{array}{c}\text { Cost } \\
\left(\$ 10^{6}\right)\end{array}$ \\
\hline $\begin{array}{l}\text { Material } \\
\text { Pipe } 1220 \mathrm{~mm} \text { extra heavy } \\
\text { Insulation }\left(76 \mathrm{~mm} \text { @ } \$ 32.28 / \mathrm{m}^{2}\right) \\
\text { Pumps }\left(0.63 \mathrm{~m}^{3} / \mathrm{s} \text { @ } 274 \mathrm{~m} \text { of head) }\right. \\
\text { Concrete piers and pipe supports }\end{array}$ & $\begin{array}{r}160.0 \\
30.0 \\
0.3 \\
79.0\end{array}$ \\
\hline Subtotal & $\overline{269.3}$ \\
\hline Labor & 628.4 \\
\hline Subtotal labor and material & $\overline{897.7}$ \\
\hline Engineering @ $25 \%$ & 224.0 \\
\hline Contingency $30 \%$ & 269.3 \\
\hline Total & 1391.0 \\
\hline
\end{tabular}

$25 \mathrm{mills} / \mathrm{kWh}$ for pumping, a fixed charge rate of $15 \%$, and a capacity factor of 1 , the unit transmission cost is estimated to be $\$ 0.07 / \mathrm{GJ} / \mathrm{km}$ (\$0.12/106 Btu-mile).

The assumption of a capacity factor of unity essentially envisions a system wherein the dual purpose plant supplies the base load heating requirements and fossil peaking stations are used to meet demand peaks. In this situation the transmission line capacity factor would indeed be near unity. If the capacity factor falls below 1 (during initial buildup of the system, or if the dual purpose plant is used to supply the base thermal load and some of the intermediate load), the unit transmission cost would rise proportionally.

Since the transmission system design utilizes a multiple pipeline design, it is expected that the estimated unit cost is valid over the range of $400-2000 \mathrm{MW}(t)$.

The pipeline delivering heat on the order of $260^{\circ} \mathrm{C}\left(500^{\circ} \mathrm{F}\right)$ is capable of serving both the industrial and commercial-residential sector. If, however, the consuming sector to be served is dominated by the commercialresidential load, heat can be supplied at lower temperature. The supply 
temperature chosen for this application was $149^{\circ} \mathrm{C}\left(300^{\circ} \mathrm{F}\right)$. At this temperature standard wall piping is sufficient to accommodate the required pressures and prefabricated insulated and encased steel pipe (conduits) is commercially available.

Table 5.2 summarizes the installed capital costs for the $149^{\circ} \mathrm{C}\left(300^{\circ} \mathrm{F}\right)$ water transport base case [delivering $2000 \mathrm{MW}(\mathrm{t})$ over a distance of $48 \mathrm{~km}$ (30 miles)].

\begin{tabular}{|c|c|}
\hline Item & $\begin{array}{c}\text { Cost } \\
\left(\$ 10^{6}\right)\end{array}$ \\
\hline Installed conduit $(1220 \mathrm{~mm})$ & 811.0 \\
\hline Pumps $\left(0.63 \mathrm{~m}^{3} / \mathrm{s} @ 274 \mathrm{~m}\right.$ of head) & 0.6 \\
\hline Subtotal & $\overline{811.6}$ \\
\hline Enginecring (c) $25 \%$ & 202.9 \\
\hline Contingency @ $30 \%$ & 243.5 \\
\hline Total. 1 . & $1.258,0$ \\
\hline
\end{tabular}

The design assumes a water velocity of $6 \mathrm{~m} / \mathrm{s}(20 \mathrm{ft} / \mathrm{sec})$, as was the case for the high temperature line, and a $111^{\circ} \mathrm{C}\left(200^{\circ} \mathrm{F}\right)$ terminal temperature drop. Therefore, five $1.22 \mathrm{~m}$ (48 in.) pipelines were required to transport the design heat load. The pumping power required for this design was 27 MW(e).

Using a power cost of $25 \mathrm{mills} / \mathrm{kWhr}$, a capacity factor of 1.0 , and a fixed charge rate of $15 \%$, the unit transmission cost is estimated to be $\$ 0.07 / \mathrm{GJ}-\mathrm{km}\left(\$ 0.11 / 10^{6} \mathrm{Btu}-\mathrm{mile}\right)$ for the low temperature pipeline.

As in the high temperature transport case it is expected that this estimate is reasonable over a heat delivery range of 400-2000 MW( $t$ ).

\section{Vapor phase transmission}

As previously stated steam and ammonia vapor were considered as candidates for the vapor phase transport medium. Steam presented several 
advantages over an ammonia system. It could be used directly in the subregion distribution grid, thereby eliminating the need for a heat exchanger at the subregion substation, and leaks from the pipeline would not seriously affect the environment. Because of these considerations it was decided to eliminate ammonia from further consideration in this study.

Vapor phase transmission economics

As in the liquid transport case, the steam transmission system was designed to deliver $2000 \mathrm{MW}(\mathrm{t})$. It was assumed that steam entered the pipeline at $260^{\circ} \mathrm{C}\left(500^{\circ} \mathrm{F}\right)$ and $4689 \mathrm{kPa}(680 \mathrm{psia})$. The estimated capital costs for this system are summarized in Table 5.3. Included in the capital costs estimates is a $406 \mathrm{~mm}$ (16 in.) diameter condensate return line and the necessary pumping equipment.

Table 5.3. Capital cost estimate for a $16 \mathrm{~km}$ (10 mile) steam pipeline supplying $2000 \mathrm{MW}(\mathrm{t})$

\begin{tabular}{|c|c|}
\hline Item & $\begin{array}{c}\text { Cost } \\
\left(\$ 10^{6}\right)\end{array}$ \\
\hline \multicolumn{2}{|l|}{ Material } \\
\hline Pipe ( $1.73 \mathrm{~m}$ diameter extra heavy) & 30.0 \\
\hline Yì̄è (4üb mm dlamecer) & 1.5 \\
\hline Condensate return pump & 0.05 \\
\hline Insulation $\$ 53.80 / \mathrm{m}^{2}$ & 18.7 \\
\hline Piers and supports & 10.56 \\
\hline Subtotal & $\overline{60.81}$ \\
\hline Labor & 141.89 \\
\hline Subtotal & 202.70 \\
\hline Engineering @ 25\% & 50.7 \\
\hline Contingency @ $30 \%$ & 60.8 \\
\hline Total & $\overline{314.2}$ \\
\hline
\end{tabular}

Based on the estimated capital costs and a $15 \%$ annual fixed charge rate the unit transmission cost is estimated to be $\$ 0.05 / \mathrm{GJ}-\mathrm{km}$ (\$0.08/106 Btu-mile). 
This cost estimate does not include costs associated with condensate formation in the steam line due to pipeline heat losses. Alternative solutions available to solve this problem are condensate removal using steam traps and the use of small electric reheat stations to vaporize the condensate.

The use of steam traps adds to the steam transport cost shown in Table 5.3 in several ways. In addition to the cost for the steam traps, removal of condensate results in a cost associated with oversizing the steam supply to meet the steam demand. Steam traps also require maintenance to operate properly and this adds to the annual operating costs. It is estimated that the use of steam traps will add $30 \%$ to the unit transport cost. Therefore, the unit cost will increase to $\$ 0.07 / \mathrm{GJ}-\mathrm{km}$ (\$0.11/106 Btu-mile).

A preliminary analysis of the electric boiler reheat option indicated that the power required for the system resulted in an unfavorable economic situation. Therefore, this option was not considered further.

\section{Subregion Distribution}

As previously described, the subregion distribution system removes heat from the long distance transport system and distributes it within the consuming subregion. For the purposes of this study the subregions have been classified as industrial or commerical-residential.

The industrial distribution network is based on steam distribution because this is the form most compatible with current industrial practice.

The commercial-residential market distribution system is based on a high-temperature hot water system (H'l'HW). Water transport was chosent hecause of its popularity and success in European systems. As demonstrated in Sect. 3, steam systems employed in the U.S, are in a virtual no growth situation while water systems in Europe are expanding. Further, there is a feeling amongst U.S. district heating operators that hot water systems would be the economic choice for any new U.S. systems because of lower maintenance and operating costs. 36 
Commercial-residential subregion costs

For cost estimating purposes the commercial-residential subregion was assumed to consist of a section dominated by single family dwellings and one of garden apartments and commercial establishments. The multifamilycommercial sector model was based on the geometric building arrangement shown in Fig. 5.1. This arrangement was chosen because a previous study 37 indicated that this arrangement ylelded the most economical piping distribution system of the many schematics considered. For the purposes of this study the apartment complex illustrated in Fig. 5.1 is referred to as the reference block.

As shown in Fig. 5.2 each apartment building is assumed to be $11 \mathrm{~m} \times$ $46 \mathrm{~m}$ (36 ft $\times 150 \mathrm{ft}$ ) with six apartments on each floor. Each apartment houses an average of 3.4 persons and provides $83.6 \mathrm{~m}^{2}\left(900 \mathrm{ft}^{2}\right)$ of living area.

The cost of installed underground conduits was estimated by adjusting the data in Ref. 38 to mid 1976 dollars. Design data and installed costs for the conduit are presented in Table 5.4. This data includes cost for a conduit applicable for high temperature hot water (HTHW) service for temperatures up to $204^{\circ} \mathrm{C}\left(400^{\circ} \mathrm{F}\right)$. It consists of steel pipe, insulation, and cast assembly with spacers inside an epoxy-coated casing. An allowance is added to these materials and prefabrication costs for expansion joints and underground installation. The data are not valid for center city areas, where costs are inflated because of site specific routing problems and concerns about vehicular traffic congestion caused by the piping installation. However, for the thermal densities of garden apartments these estimates should give reasonable results. Even though cost per foot of length of prefabricated conduit varies over a wide range, and each specific site must have engineered systems, estimating total installed cost as a percentage of materials seems to give acceptable estimates. Also, for similar temperatures and pressures, the conduit costs can be used for estimating thermal energy transport system costs to specific demands of commercial or industrial sites.

Cost of a piping distribution system sized for 240 two- and threestory apartment buildings were evaluated for peak energy demand loads 


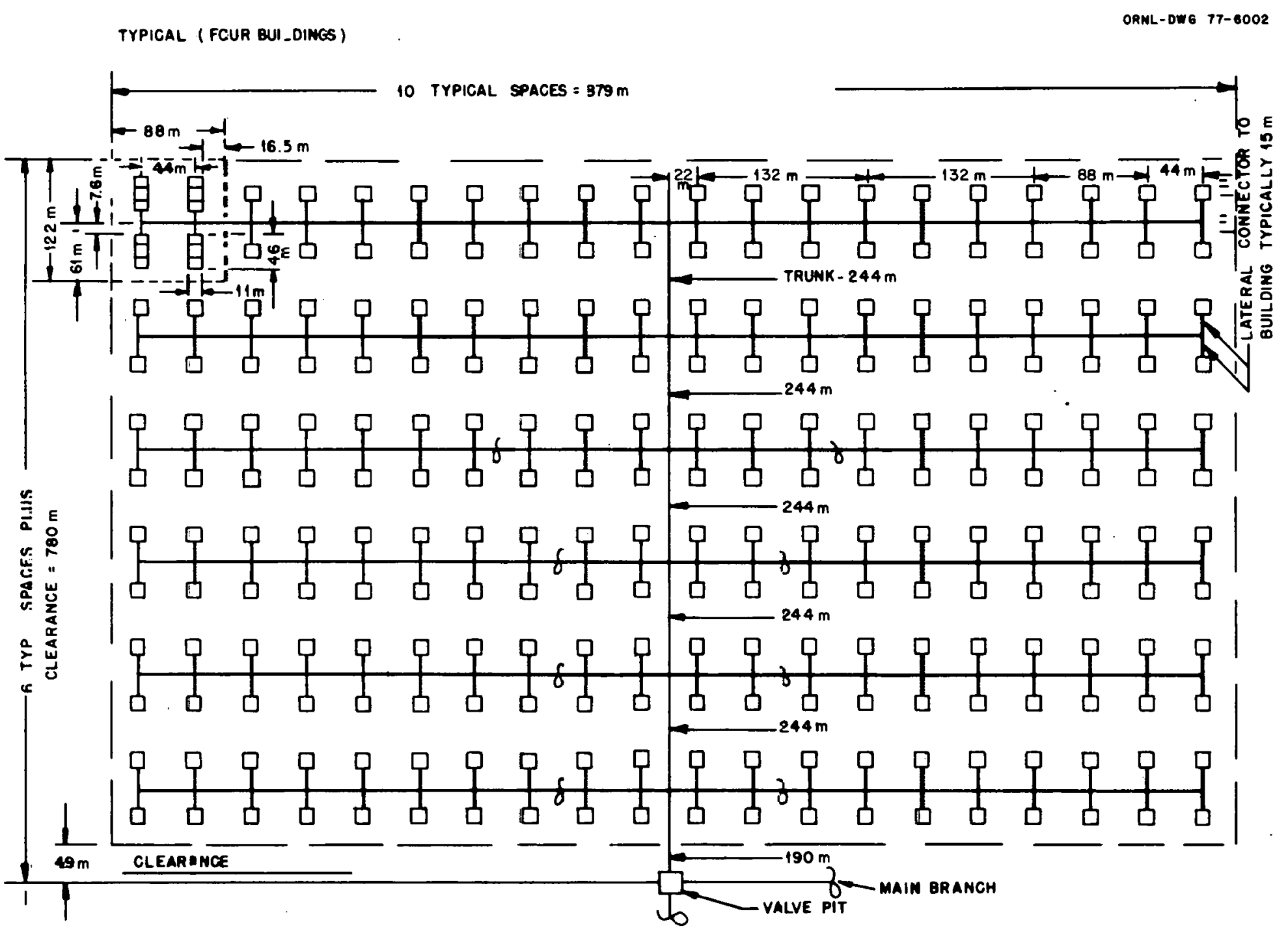

Fig. 5.1. Geometric building arrangement for distribution system. 
ORNL-DWG 77-6004

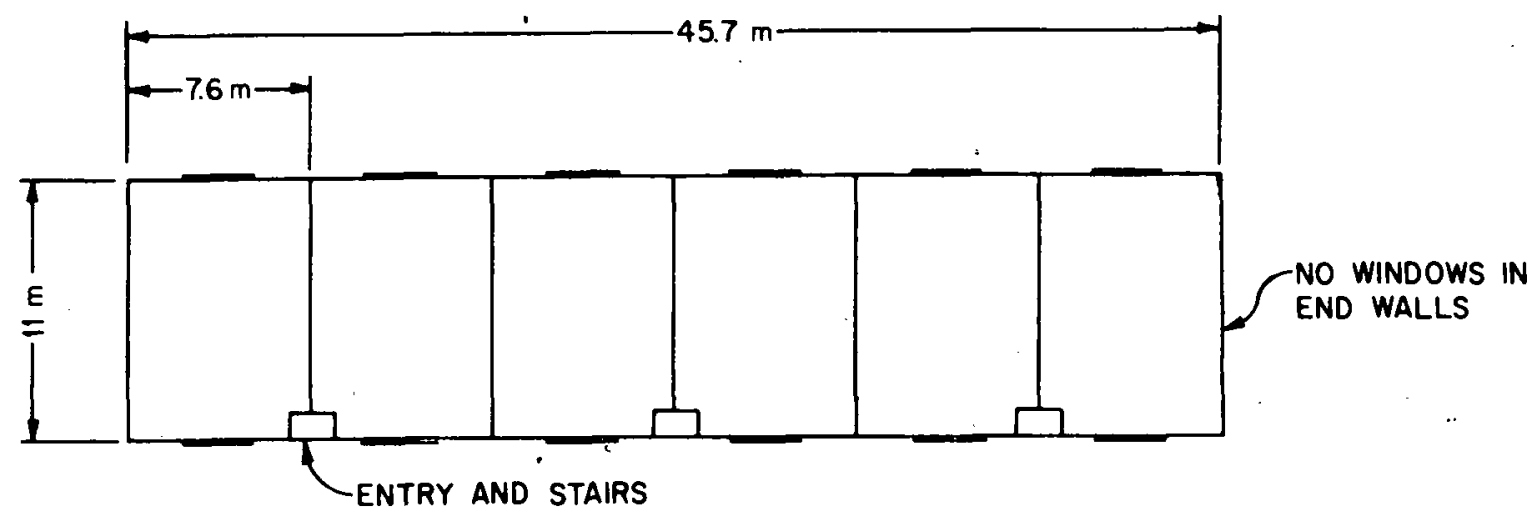

TWO-STORY BUILDING $83.6 \mathrm{~m}^{2}$ FLOOR AREA PER APARTMENT 12 APARTMENTS PER BUILDING AVG. 3.4 PERSONS PER APT. $7.4 \mathrm{~m}^{2}$ GLASS AREA PER APARTMENT

Fig. 5.2. Garden apartment building. 
Table 5.4. Design data and installed cost of HTHW conduit

\begin{tabular}{|c|c|c|c|c|c|c|}
\hline $\begin{array}{l}\text { Nominal } \\
\text { pipe } \\
\text { diameter } \\
(\mathrm{mm})\end{array}$ & $\begin{array}{c}\text { Flow } \\
\underset{\left(10^{3} \mathrm{~mm}^{2}\right)}{\text { area }}\end{array}$ & $\begin{array}{l}\text { Maximum } \\
\text { flow } \\
\text { rate } \\
(\mathrm{kg} / \mathrm{s})\end{array}$ & $\begin{array}{c}\text { Reynolds } \\
\text { number } \\
\left(10^{6}\right)\end{array}$ & $\begin{array}{c}\text { Friction } \\
\text { factor }\end{array}$ & $\begin{array}{c}\text { Pressure } \\
\text { drop } \\
(\mathrm{kPa} / 1000 \mathrm{~m})\end{array}$ & $\begin{array}{c}\text { Installed } \\
\text { cost } \\
(\$ / \mathrm{m})\end{array}$ \\
\hline 19.1 & 0.3 & 0.77 & 0.246 & 0.0235 & 3051 & 49.2 \\
\hline 25.4 & 0.6 & 1.25 & 0.314 & 0.0225 & 228.3 & $51 . .5$ \\
\hline 31.8 & 1.0 & 2.15 & 0.413 & 0.0210 & 1627 & 54.5 \\
\hline 38.1 & 1.3 & 2.94 & 0.482 & 0.0205 & 1356 & 59.1 \\
\hline 50.8 & 2.2 & 4.84 & 0.618 & 0.0195 & 1010 & 64.6 \\
\hline 63.5 & 3.1 & 6.93 & 0.739 & 0.0185 & 809 & 68.9 \\
\hline 76.2 & 4.8 & 10.7 & 0.918 & 0.0180 & 633 & 73.8 \\
\hline 101.6 & 8.2 & 18.4 & 1.20 & 0.0165 & 441 & 87.3 \\
\hline 152.4 & 18.6 & 41.7 & 1.81 & 0.0153 & 271 & 121.0 \\
\hline 203.2 & 32.3 & 72.2 & 2.39 & U. U142 & $\dot{i} \dot{y}$ & $15 \%$ \\
\hline 254.0 & 50.9 & 113.9 & 3.00 & 0.0137 & 147 & 205.4 \\
\hline 304.8 & 72.2 & 161.7 & 3.57 & 0.0130 & 117 & 269.0 \\
\hline 355.6 & 89.0 & 199.2 & 3.96 & 0.0128 & 90 & 308.4 \\
\hline 406.4 & 1.1 .7 .8 & 263.7 & $4: 56$ & 0.0125 & 79 & 383.9 \\
\hline 457.2 & 148.7 & 322.8 & 5.13 & 0.0122 & 76 & 475.7 \\
\hline 508.0 & 182.9 & 409.5 & 5.68 & 0.0120 & 63 & 557.7 \\
\hline 558.8 & 223.5 & 500.3 & 6.28 & 0.0118 & 59 & 613.5 \\
\hline .609 .6 & 271.0 & 606.7 & 6.92 & 0.0117 & 54 & 705.4 \\
\hline 762.0 & 418.1 & 935.9 & 8.60 & 0.0112 & 42 & 895.7 \\
\hline 914.4 & 611.6 & 1369.1 & 10.4 & $0: 0107$ & 33 & 1082.7 \\
\hline 1066.8 & 838.7 & 1877.7 & 12.2 & 0.0105 & 28 & 1407.5 \\
\hline 1219.2 & 1095.5 & 2452.5 & 13.9 & 0.0103 & 24 & $1,679.8$ \\
\hline 1371.6 & 1396.8 & 3126.9 & 15.7 & 0.0100 & 20 & 1968.5 \\
\hline 1524.0 & 1734.2 & 3882.1 & 17.5 & 0.0095 & 17 & 2398.3 \\
\hline
\end{tabular}

$u_{\text {Schedule }} 40$ for pipes through $304.8 \mathrm{~mm}$ and standard wall for 355.6 through $1524.0 \mathrm{~mm}$.

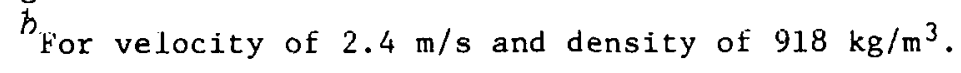

(includes both space and hot water heating) of $2.8-8.4 \mathrm{~kJ} / \mathrm{s}-\mathrm{apt} .(10,000-$ $30,000 \mathrm{Btu} / \mathrm{hr}$-apt.). These loads are representative of various climatic regions in the U.S., as shown in Table 5.5, for buildings constructed in accordance with the February 1976 updated HUD Multifamily Housing Minimum Property Standards and the outdated 1971 standards. The 1971 standards were included to allow analysis of retrofit situations.

A typical set of the tabulated data, required to size a piping system for a block of 240 two-story apartment buildings, is included in Table 5.6. This table lists the heating energy demand required for each increase in the number of buildings as they are added to formulate the matrix shown in Fig. 5.1. Then a pipe size is selected to meet each accumulated 
Table 5.5. Estimated energy demand for selected sites

\begin{tabular}{|c|c|c|c|c|}
\hline \multirow{2}{*}{ City } & \multicolumn{2}{|c|}{1976 HUD standards } & \multicolumn{2}{|c|}{1971 HUD standards } \\
\hline & Space heat only & $\begin{array}{l}\text { Space and } \\
\text { water heat }\end{array}$ & Space heat only & $\begin{array}{l}\text { Space and } \\
\text { water heat }\end{array}$ \\
\hline \multicolumn{5}{|c|}{ Peak energy demands ( $\mathrm{J} / \mathrm{s}-\mathrm{apt})}$. \\
\hline Philadelphia & 2740 & 3300 & 5430 & 5990 \\
\hline Atlanta & 3250 & 3810 & 5850 & $6410 \ldots-$ \\
\hline Chicago & 3810 & 4370 & 6830 & 7390 \\
\hline Minneapolis & 4400 & 4960 & 7900 & 8460 \\
\hline Dallas & 3000 & 3560 & 4870 & 5430 \\
\hline \multicolumn{5}{|c|}{ Yearly energy use (GJ/year-apt.) } \\
\hline Philadelphia & 12.0 & 32.0 & 27.3 & 47.9 \\
\hline Atlanta & 9.0 & 29.0 & 20.7 & 40.7 \\
\hline Chicago & 17.0 & 37.0 & 32.0 & 52.0 \\
\hline Minneapolis & 25.0 & 45.0 & 47.3 & 67.3 \\
\hline Da1las & 6.0 & 26.0 & 13.8 & 34.3 \\
\hline
\end{tabular}

demand based on a maximum water velocity, the transverse area of pipe, and the average temperature drop assumed for the HTHW.

The estimated cost per apartment of distribution piping for $149^{\circ} \mathrm{C}$ $\left(300^{\circ} \mathrm{F}\right)$ HTHW to the reference block for various peak heat demands is presented in Table 5.7. The estimates are given for temperature drops at the user's end, of $37.8^{\circ} \mathrm{F}\left(100^{\circ} \mathrm{F}\right)$ for both two- and three-story apartment buildings. The cost of these systems is based on a maximum flow velocity of $2.4 \mathrm{~m} / \mathrm{sec}(8 \mathrm{ft} / \mathrm{sec})$.

Based on the capital cost estimates in Table 5.7 and the total yearly heating energy use estimates from Table 5.5, the unit subregion heat distribution costs for the various climates were computed. Table 5.8 presents these unit heat costs for multifamily dwellings constructed in accordance with both the new and outdated HUD standards for various cities in the U.S. This analysis was based on utility financing and assumed a fixed charge rate of $15 \%$. 
Table 5.6. High temperature hot water distribution system design (two-story building, $\Delta \mathrm{T}=55.6^{\circ} \mathrm{C}$,

$8.4 \mathrm{~kJ} / \mathrm{s}$-apt. peak demand, and velocity $=2.4 \mathrm{~m} / \mathrm{s}$ )

\begin{tabular}{|c|c|c|c|c|c|}
\hline $\begin{array}{l}\text { No. of } \\
\text { buildings }\end{array}$ & $\begin{array}{c}\text { No. of } \\
\text { apartments }\end{array}$ & $\begin{array}{l}\text { Heating } \\
\text { energy } \\
\text { required } \\
(\mathrm{kJ} / \mathrm{s})\end{array}$ & $\begin{array}{l}\text { Flow area } \\
\text { required } \\
\left(10^{3} \text { 11u1 }{ }^{2}\right)\end{array}$ & $\begin{array}{c}\text { Selected pipe } \\
\text { diameter } \\
\text { (unil) }\end{array}$ & $\begin{array}{c}\text { Deliverable } \\
\text { energyb } \\
(\mathrm{kJ} / \mathrm{s})\end{array}$ \\
\hline 1 & 12 & 100.8 & 0.2 & 25 & 277.2 \\
\hline 2 & 24 & 201.6 & 0.4 & 32 & 481.6 \\
\hline 4 & 48 & 403.2 & 0.8 & 38 & 655.2 \\
\hline 6 & 72 & 604.8 & 1.2 & 38 & 655.2 \\
\hline 8 & 96 & 806.4 & 1.6 & 51 & $1,064.0$ \\
\hline 10 & 120 & $1,008.0$ & 2.0 & 51 & $1,064.0$ \\
\hline 12 & 144 & $1,209.6$ & 2.4 & 64 & $1,512.0$ \\
\hline 14 & 168 & $1,411.2$ & 2.8 & 64 & $1,512.0$ \\
\hline 16 & 192 & $1,612.8$ & 3.2 & 76 & $2,380.0$ \\
\hline 18 & 216 & $1,814.4$ & 3.6 & 76 & $2,380.0$ \\
\hline 20 & 240 & $2,016.0$ & 4.0 & 76 & $2,380.0$ \\
\hline 40 & 480 & $4,032.0$ & 8.1 & 102 & $4,088.0$ \\
\hline 60 & 720 & $6,048.0$ & 12.1 & 152 & $9,268.0$ \\
\hline 80 & 960 & $8,064.0$ & 16.2 & 152 & $9,268.0$ \\
\hline 100 & 1,200 & $10,080.0$ & 20.3 & 203 & $15,960.0$ \\
\hline 120 & 1,440 & $12,096.0$ & 24.3 & 203 & $15,960.0$ \\
\hline 160 & 1,920 & $14,728.0$ & 32.4 & 203 & $15,960.0$ \\
\hline 180 & 2,160 & $18,144.0$ & 36.5 & 254 & $25,312.0$ \\
\hline 200 & 2,400 & $20,160.0$ & 40.5 & 254 & $25,312.0$ \\
\hline $240^{\circ}$ & 2,880 & $24,192.0$ & 48.6 & 254 & $25,312.0$ \\
\hline 480 & 5,760 & $48,384.0$ & 97.2 & 406 & $50,680.0$ \\
\hline 720 & 8,640 & $72,576.0$ & 145.8 & 457 & $73,920.0$ \\
\hline 960 & 11,520 & $96,768.0$ & 194.2 & 559 & $111 ; 160.0$ \\
\hline 1200 & 14,400 & $120,960.0$ & 243.9 & 610 & $134,960.0$ \\
\hline 1440 & 17,280 & $145,152.0$ & 291.6 & 762 & $208,040.0$ \\
\hline 1720 & 23,040 & $112,896.0$ & 388.4 & 762 & $208,040.0$ \\
\hline 2400 & 28,800 & $241,920.0$ & 485.8 & 914 & $305,200.0$ \\
\hline 3880 & 31,560 & $290,360.0$ & 583.2 & 914 & $305,200.0$ \\
\hline
\end{tabular}

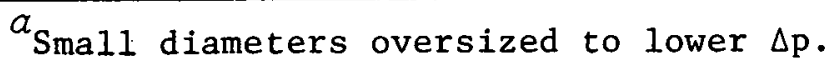

$b_{\text {Based on area of selected pipe size (see Table 5.4) }}$

Elock of apartments used as reference plot. 
Table 5.7. Cost estimates for HTHW distribution systems to reference block of 240 apartments

\begin{tabular}{lcccc}
\hline \multirow{2}{*}{ Building height } & \multicolumn{3}{c}{ Peak energy demand } & \multicolumn{2}{c}{ (J/s-apt.) } \\
\cline { 2 - 5 } & 2800 & 4760 & 6720 & 8400 \\
\hline Two story cost (\$/apt.) & 343 & 358 & 385 & 398 \\
Three story cost (\$/apt.) & 237 & 261 & 286 & 311 \\
\hline
\end{tabular}

It is evident from Table 5.8 that the unit heat cost associated with subregional distribution is substantially reduced when the space and hot water needs are satisfied by the thermal grid. This is not surprising since the hot water load does not add significantly to the peak demand but does have a major effect on the total yearly energy use. Therefore, only a small incremental cost is needed for the additional peak but a large annual load is added, which reduces the annualized unit subregion distribution cost.

Previous investigations ${ }^{39}$ suggest that the space heating demand for commercial and low rise apartments is nearly equal. Therefore, for the purposes of this study it was assumed that a portion of the apartment buildings was equivalent to an appropriate number of commercial establishments. Hence the reference block previously described was considered adequate for the commercial-residential sector composed of garden apartments and a mix of offices, retail shops, schools, hospitals and other commercial establishments.

The cost to supply a number of reference blocks is highly dependent upon the arrangement of the blocks. It is probable that the additional blocks can be arranged such that the cost for the larger main required is balanced by the additional load. In this instance the unit subregion transport costs would be equal to those presented in Table 5.8. For the purposes of this study it was assumed that the costs in Table 5.8 are applicable to a multi-block system.

Supplying single family residences was also considered in the residential subregion. For HTHW piping to a single family dwelling in blocks of 15 houses per hectare (six houses per acre), distribution piping costs 
Table 5.8. Unit heat Aistrijution costs for multifamily sector

\begin{tabular}{|c|c|c|c|c|c|c|c|c|}
\hline \multirow{3}{*}{ City } & \multicolumn{4}{|c|}{1975 HUD standards } & \multicolumn{4}{|c|}{1971 HUD standards } \\
\hline & \multicolumn{2}{|c|}{$\begin{array}{l}\text { Capital cost } \\
\quad(\$ / \text { apt.) }\end{array}$} & \multicolumn{2}{|c|}{$\begin{array}{c}\text { Init heat cost } \\
(\$ ! G J)\end{array}$} & \multicolumn{2}{|c|}{$\begin{array}{l}\text { Capital cost } \\
\text { (\$/apt.) }\end{array}$} & \multicolumn{2}{|c|}{$\begin{array}{c}\text { Unit heat cost } \\
(\$ / G J)\end{array}$} \\
\hline & 2 story & 3 story & 2 story & 3 story & 2 story & 3 story & 2 story & 3 story \\
\hline & \multicolumn{8}{|c|}{ Space and domestic water heating } \\
\hline Philaćelphia & 350 & 245 & $=64$ & 1.15 & 375 & 280 & 1.17 & 0.88 \\
\hline Atlanta & 350 & 245 & $i .81$ & 1.27 & 380 & 285 & 1.40 & 1.08 \\
\hline Chicago & 360 & 260 & $i-46$ & 1.05 & 390 & 295 & 1.13 & 0.85 \\
\hline Minneapolis & 365 & 267 & i. 22 & 0.89 & 400 & 310 & 0.88 & 0.68 \\
\hline \multirow[t]{2}{*}{ Dallas } & 350 & 245 & 2.02 & 1.41 & 370 & 275 & 1.63 & 1.21 \\
\hline & \multicolumn{8}{|c|}{ Space heat only } \\
\hline Philadelphia & 342 & 265 & L. 28 & 3.31 & 370 & 275 & 2.03 & 1.51 \\
\hline Atlanta & 350 & 245 & 5.83 & 4.17 & 370 & 275 & 2.68 & 1.99 \\
\hline Chicago & 355 & 250 & 3.13 & 2.21 & 380 & 285 & 1.78 & 1.34 \\
\hline Minneapolis & 360 & 258 & 2.17 & 1.55 & 395 & 305 & 1.25 & 0.97 \\
\hline Dallas & 342 & 265 & \&. 55 & 6.63 & 365 & 265 & 3.97 & 2.88 \\
\hline
\end{tabular}


were on the order of $\$ 2200$ per home with demand loads of $11.2 \mathrm{~kJ} / \mathrm{s}$ $(40,000 \mathrm{Btu} / \mathrm{hr})$. This peak heat load is representative of a $167 \mathrm{~m}^{2}$ (1800 $\mathrm{ft}^{2}$ ) house located in Philadelphia constructed in accordance with the 1976 HUD standards. Using utility financing (15\% fixed charge rate) and assuming hot water demands are also satisfied by the thermal grid, this corresponds to a unit heat transport costs of $\$ 5.32 / G J$-house $(\$ 5.32 /$ $10^{6}$ Btu-house). This cost appeared representative for single family units and was used as the units distribution costs for the single family residence sector of the residential-commercial subregion.

\section{Industrial subregion distribution costs}

A recent study ${ }^{4}$ of industrial steam use has indicated that approximately $85 \%$ of industrial heat demand is satisfied with steam below $204^{\circ} \mathrm{C}$ $\left(400^{\circ} \mathrm{F}\right)$. Therefore, it was assumed that saturated steam at $1724 \mathrm{kPa}$ (250 psig) was supplied to the industrial subregion distribution system. An analysis of the data presented in Ref. 4 indicated that an industrial site having a $6.4 \mathrm{~km}$ ( 4 mile) diameter contained an average of 3 industries, each having an average steam usage of $63 \mathrm{~kg} / \mathrm{s}(500,000 \mathrm{lb} / \mathrm{hr})$. Similarly, industrial sites with a $16 \mathrm{~km}$ (10 mile) diameter had three industries with an average steam demand of about $126 \mathrm{~kg} / \mathrm{s}\left(1 \times 10^{6} \mathrm{lb} / \mathrm{hr}\right)$ per industry and industrial sites with a $32 \mathrm{~km}$ (20 mile) diameter contained 7 industries each having a steam demand of about $126 \mathrm{~kg} / \mathrm{s}$ $\left(1 \times 10^{6} \mathrm{lb} / \mathrm{hr}\right)$.

Based on these results, it was assumed that the industrial subregion distribution system consisted of a steam supply substation centrally located in the industrial site with steam distribution lines extending to each industry. Condensate return lines are also provided to return condensate to the substation.

The physical design of the substation would depend upon the transport media in the long distance pipeline. If steam is used in the cross country line, then the substation would merely tap into the pipeline and bleed off an appropriate amount of energy. If HTHW is used, then the substation could flash the water into steam at the appropriate pressure. 
The industrial subregion steam distribution costs were developed consistent with the design criteria previously mentioned. The design data and capital costs summary are presented in Table 5.9.

The unit transport costs presented in Fig. 5.3 are based on the capital costs in Table 5.9. It was assumed that the pipeline was in continuous use, hence a capacity factor of 1.0 was used, and $15 \%$ of the energy is lost during transport. Utility financing was assumed; therefore, a fixed charge rate of $15 \%$ was used.

\section{Supply of Chilled Water}

In an effort to increase the annual utilization factor of the heat transport pipeline, supply of chilled water for air conditioning of the commerical-residential sector was considered. The system essentially consists of a central steam turbine water chiller unit and the piping network required to transport the chilled water to the subregion. Steam required by the turbine drive unit is obtained either directly from the long distance transport line, when steam is used as the transport media, or by flashing the water, when HTHW is used.

The chilled water system was designed for various peak load demands representative of various climatic conditions in the U.S. Peak cooling demand data and annual cooling use for selected sites is shown in Table 5.10. The cooling loads have been computed for both the updated 1976 HUD standards and the 1971 HUD standards for consideration of both new and retrofit applications.

The chilled water distribution costs were calculated in a manner similar to the heat distribution costs for the reference block shown in Fig. 5.1. The installed costs per apartment shown in Table 5.11 were based on a water velocity of $2.4 \mathrm{~m} / \mathrm{s}(8 \mathrm{ft} / \mathrm{sec})$ and a temperature drop of $8^{\circ} \mathrm{C}\left(15^{\circ} \mathrm{F}\right)$.

The installed costs for steam turbine driven water chillers were developed using cost data from Richardson's Cost Estimator ${ }^{40}$. Figure 5.4 presents the installed unit cost as a function of the size of the unit.

The unit cost for production and distribution of chilled water was computed using the cost information in Fig. 5.4 and Table 5.11 and the 
Table 5.9. Design and capital cost summary for industrial subregion steam distribution

\begin{tabular}{|c|c|c|c|c|c|c|c|c|c|c|}
\hline $\begin{array}{l}\text { Steam flow } \\
(\mathrm{kg} / \mathrm{s})\end{array}$ & $\begin{array}{l}\text { Conduit } \\
\text { diameter } \\
\text { imm) }\end{array}$ & $\begin{array}{l}\text { Pressure } \\
\text { (kPa/1000 m) }\end{array}$ & $\begin{array}{l}\text { Maximum }_{b} \\
\text { distance } \\
\text { (km) }\end{array}$ & $\begin{array}{l}\text { Actual } \\
\text { distance } \\
(\mathrm{km})\end{array}$ & $\begin{array}{c}\text { Steam flow } \\
(\mathrm{kg} / \mathrm{s})\end{array}$ & $\begin{array}{l}\text { Steam pipe } \\
\text { diameter } \\
(\mathrm{mm})\end{array}$ & $\begin{array}{c}\text { Condensate } \\
\text { diameter } \\
(\mathrm{mm})\end{array}$ & $\begin{array}{l}\text { Steam } \\
\text { conduitt } \\
\text { costd } \\
(\$ / \mathrm{m})\end{array}$ & $\begin{array}{c}\text { Condensate } \\
\text { conduit } \\
\text { cost } d \\
(\$ / \mathrm{m})\end{array}$ & $\begin{array}{l}\text { Total } \\
\text { cost } \\
(\$ / \mathrm{m})\end{array}$ \\
\hline \multicolumn{5}{|c|}{ Design characteristics } & \multicolumn{6}{|c|}{ Capital cost summary } \\
\hline 32.0 & 508 & 40.7 & 15.8 & 14.2 & 32.0 & 508 & 152 & 557.7 & 121.4 & 679.1 \\
\hline 64.0 & 610 & 63.3 & 10.8 & 9.1 & 64.0 & 610 & 254 & 705.4 & 206.7 & 912.1 \\
\hline 96.0 & 762 & 36.2 & 13.9 & 16.0 & 96.0 & 762 & 305 & 895.7 & 269.0 & 1164.7 \\
\hline 128.0 & 914 & 27.1 & 25.3 & 21.4 & 128.0 & 914 & 356 & 1082.7 & 308.4 & 1391.1 \\
\hline 192.0 & 1067 & 27.1 & 25.3 & 21.4 & 192.0 & 1067 & 406 & 1407.5 & 383.9 & 1791.4 \\
\hline
\end{tabular}

a Saturated steam suppliec to distribution system at $1724 \mathrm{kPa}$ saturated.

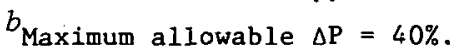

$\dot{c}_{\text {Assuming }} 15 \%$ loss of energy during transport.

$d_{\text {From Table } 5.4 \text {. }}$ 


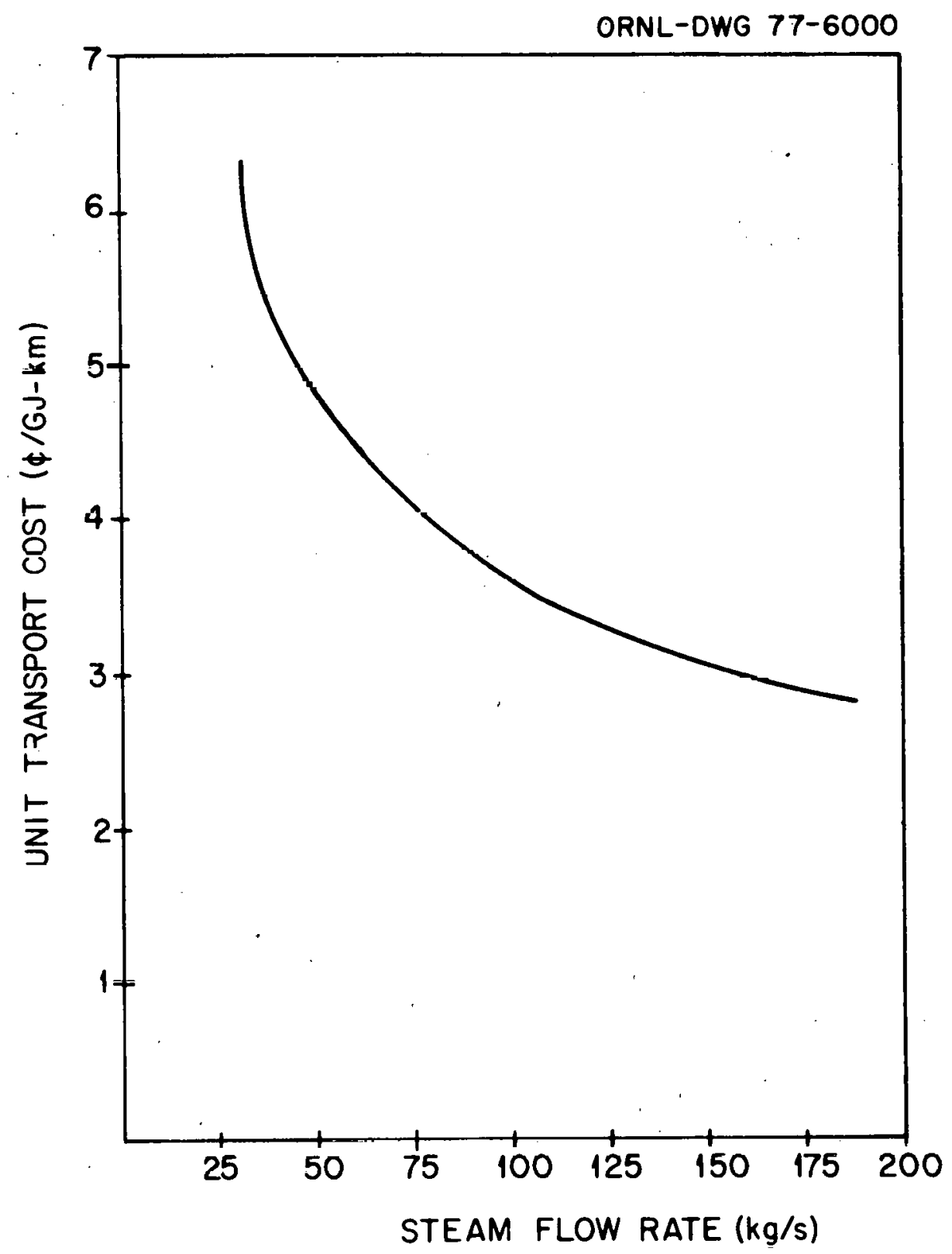

Fig. 5.3. Industrial subregion unit steam transport costs. 
Table 5.10. Cooling demand data for selected cities

\begin{tabular}{|c|c|c|c|}
\hline City & 1976 HUD & standards & 1971 HUD standards \\
\hline . & \multicolumn{3}{|c|}{ Peak cooling demand (kW/apt.) } \\
\hline $\begin{array}{l}\text { Philadelphia } \\
\text { Atlanta } \\
\text { Chicago } \\
\text { Minneapolis } \\
\text { Dallas }\end{array}$ & & $\begin{array}{l}2.65 \\
2.37 \\
3.13 \\
2.84 \\
3.16\end{array}$ & $\begin{array}{l}4.64 \\
3.88 \\
5.08 \\
4.64 \\
4.99\end{array}$ \\
\hline Dallas & Annual & cooling demand & (kWhr/apt.-year) \\
\hline $\begin{array}{l}\text { Philadelphia } \\
\text { Atlanta } \\
\text { Chicago } \\
\text { Minneapolis } \\
\text { Dallas }\end{array}$ &. & $\begin{array}{l}3473 \\
4609 \\
3031 \\
2557 \\
6787\end{array}$ & $\begin{array}{r}6,724 \\
8,988 \\
6,516 \\
5,493 \\
13,322\end{array}$ \\
\hline
\end{tabular}

Tále 5.11. Cusl esilinaces for chilled water distribution to reference block

\begin{tabular}{ccccc}
\hline \multirow{2}{*}{$\begin{array}{c}\text { Building height } \\
\text { Two story (\$/apt.) }\end{array}$} & \multicolumn{2}{c}{ Peak cooling demand } & \multicolumn{2}{c}{ (kw/apt.) } \\
\cline { 2 - 5 } & 2.93 & 4.40 & 5.13 & 5.86 \\
\hline Three story (\$/apt.) & 158 & 187 & 206 & 225 \\
\hline
\end{tabular}




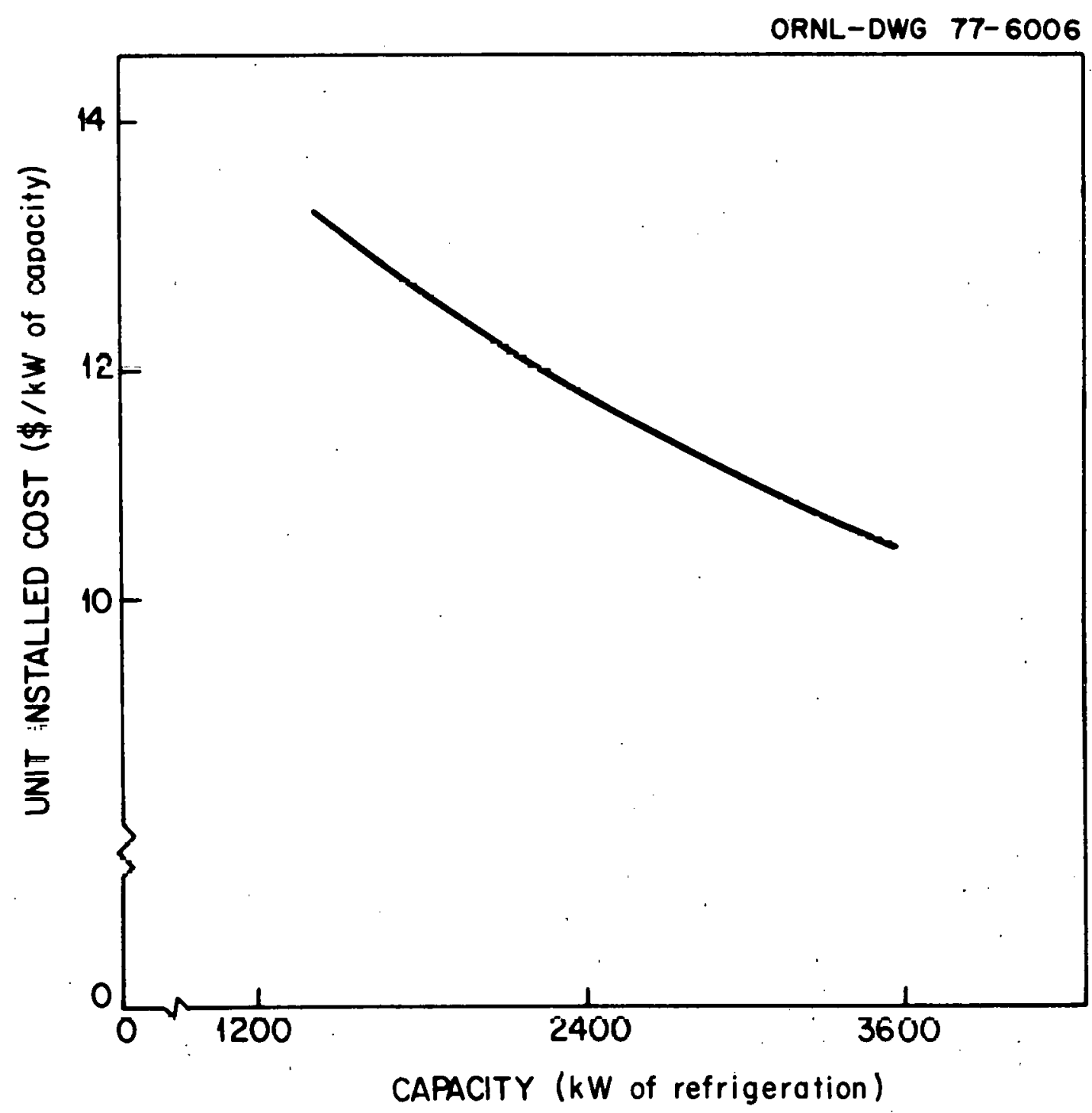

Fig. 5.4. Unit installed cost for turbine driven chiller unit. 
annual demand figures from Table 5.10. The results for the selected sites, using a fixed charge rate of $15 \%$, are shown in Table 5.12. In estimating the unit cost for chilled water the chiller unit was oversized by $5 \%$ to account for distribution losses.

Table 5.12. Unit chilled water costs

\begin{tabular}{|c|c|c|c|c|}
\hline \multirow[t]{2}{*}{ City } & \multicolumn{2}{|c|}{$\begin{array}{c}\text { Total cost } \\
\text { (\$/apt.) }\end{array}$} & \multicolumn{2}{|c|}{$\begin{array}{c}\text { Unit cost } \\
(\$ / G J)\end{array}$} \\
\hline & 2 story & 3 story & 2 story & 3 story \\
\hline . & \multicolumn{4}{|c|}{1976 HUD standards } \\
\hline $\begin{array}{l}\text { Philadelphia } \\
\text { Atlanta } \\
\text { Chicago } \\
\text { Minneapolis } \\
\text { Dallas }\end{array}$ & $\begin{array}{l}329 \\
313 \\
356 \\
342 \\
359\end{array}$ & $\begin{array}{l}287 \\
271 \\
314 \\
298 \\
317\end{array}$ & $\begin{array}{l}3.74 \\
2.68 \\
4.64 \\
5.29 \\
2.09\end{array}$ & $\begin{array}{l}3.26 \\
2.32 \\
4.10 \\
4.61 \\
1.84\end{array}$ \\
\hline Dallas & \multicolumn{4}{|c|}{1971 HUD standards } \\
\hline $\begin{array}{l}\text { Philadelphia } \\
\text { Atlanta } \\
\text { Chicago } \\
\text { Minneapolis } \\
\text { Dallas }\end{array}$ & $\begin{array}{l}442 \\
406 \\
468 \\
442 \\
458\end{array}$ & $\begin{array}{l}396 \\
358 \\
422 \\
396 \\
416\end{array}$ & $\begin{array}{l}2.59 \\
1.78 \\
2.83 \\
3.17 \\
1.36\end{array}$ & $\begin{array}{l}2.32 \\
1.57 \\
2.55 \\
2.84 \\
1.23\end{array}$ \\
\hline
\end{tabular}

Distribution of chilled water to the single family resident sector was not considered in this study because the distribution costs appeared to be prohibitive.

\section{Impact of Improved Distribution Technology}

One approach to reducing the cost for heat from the thermal grid is to reduce the costs associated with transporting the heat. Improving heat transport technology is the objective of current investigations in Sweden. 6 The thrust of this work is to develop cheaper noncorroding warm water pipes which can be laid directly in the ground. 
Two technologies are now under development in Sweden. The first utilizes pipes of glassfiber armoured plastic. They are insulated with a cellular plastic and covered with a protective sheet. The second technology under consideration uses pipes of reinforced concrete with an inner lining of plastic and plastic concrete to prevent leaching of the concrete by hot water. The exterior is surrounded by a cast insulation.

In both cases the basic pipe material would not be damaged if ground water was to reach it through damaged insulation. Sliding telescopic type joints with artificial rubber tightening rings could he user in place of expensive expansion joints yielding further cost savings.

The temperature for which these pipes can be used is determined by the type of plastic used and the sealing method chosen. Some small glass fiber armoured pipes have been used in district heating systems in Germany. The pipes have performed well at the normal operating temperature of $130^{\circ} \mathrm{C}\left(266^{\circ} \mathrm{F}\right)$. In this application a relatively expensive epoxy was used with solid joints. Use of a cheaper resin and telescopic joints may limit operating temperatures to about $100^{\circ} \mathrm{C}\left(212^{\circ} \mathrm{F}\right)$. However, further research may indicate design variations to accommodate higher operating temperatures.

Swedish cost calculations ${ }^{6}$ indicate that the new piping technologies show a 40 to $50 \%$ cost savings compared to the conventional steel pipe in a concrete culvert method. These cost calculations also show savings of 20 to $40 \%$ compared to steel pipe installed above ground on concrete piers. Because of operating temperature limitations, these piping improvements would be utilized most effectively in reducing the distribution costs within the commercial-residential subregion.

\section{ECONOMICS AT POINT OF CONSIMPTION}

The economics at the point of consumption were examined to determine the consumer breakeven price for heat from the thermal grid. The consumer breakeven price considers economics from the consumer's viewpoint. The analysis considers the costs involved for the home or building owner to utilize heat from the grid. The breakeven price, then, is the maximum price a consumer could pay for heat from the grid and have the heating 
cost competitive with conventional systems. Essentially, the utility must sell heat from the grid at a price no higher than the consumers breakeven price to be competitive with conventional systems.

Alternate conventional systems using natural gas, oil, and electricity are used as the basis for determining the consumer breakeven price.

Both new and retrofit applications are considered for each of the consuming subregions. As used in this section, retrofit applications refer to situations where the consumer has a heating and cooling system in place. The cost for thermal grid heat or chilled water must be balanced against continued use of the present system. Therefore, the breakeven price will account for present operational (including fuel) costs and additional capital investment associated with additional equipment to utilize heat from the grid.

New applications refer to situations when the consumer is making a decision as to what type of system to install. Therefore, the breakeven price will include the above mentioned costs and consideration of capital costs associated with alternate conventional systems.

\section{Residential-Commercial Heating Systems}

The residential-commercial subregion breakeven costs were evaluated for hnth the single family dwelling and the commercial-multifamily residential sectors. Since the distribution cost results strongly indicated that supplying domestic hot water. enhanced the feasibility of the concept, the breakeven cost evaluations were performed assuming spacé and wacer heating demands were met by the thermal grid.

\section{Multifamily residential-commercial sector}

The procedure selected for this assessment utilizes specific consumer district heating and conventional utility models which represent typical examples of heating, ventilating and air conditioning (HVAC) systems. The HVAC equipment models serve as working tools to help estimate relative impacts and economic feasibility of utilizing thermal energy from a thermal grid. 
The HVAC and domestic hot water equipment discussed in this section consists of only the components located within the multifamily buildings, either in the basement or the individual dwelling units. HVAC systems for multifamily buildings have been classified into two categories:

district systems, and central building systems.

The district system HVAC equipment utilizing energy from a thermal grid is assumed to consist of only those components located within the building. External sources of heat and chilled water are located outside of the individually serviced buildings. The district HVAC equipment discussed in this section begins with the thermal distribution 1 ines leading up to the building perimeter, delivering hot water at about $140^{\circ} \mathrm{C}\left(285^{\circ} \mathrm{F}\right)$ year around and chilled water at abnut $6^{\circ} \mathrm{C}\left(43^{\circ} \mathrm{F}\right)$ during the cooling season.

The central building systems refer to a HVAC system with no thermal distribution lines feeding into the individual buildings. Some means of both generating and rejecting heat is provided within the building. At least some of the building equipment is located outside of the individual dwelling units, usually in the basement.

The apartment complex model used for this evaluation is the same as that presented in Fig. 5.2. Three reference climates are assumed and the design heating and cooling loads are used to size the HVAC equipment. The three design conditions, shown in Table 6.1, correspond to housing constructed in accordance with the 1971 HUD standards. HVAC costs for newer housing was estimated by performing a sensitivity analysis to determine the effect of climate on system costs.

Table 6.1. Heating and cooling design loads ${ }^{a}$

\begin{tabular}{lcc}
\hline & $\begin{array}{c}\text { Spact lisating and } \\
\text { domestic hot water } \\
(\mathrm{kW})\end{array}$ & $\begin{array}{c}\text { Space cooling } \\
(\mathrm{kW})\end{array}$ \\
\hline Philadelphia & 7.03 & 5.28 \\
Dallas & 6.15 & 5.86 \\
Minneapolis & 8.79 & 4.98 \\
\hline \multicolumn{2}{c}{$a_{1971 \text { HUD standards. }}$}
\end{tabular}




\section{District HVAC system}

Once hot and chilled water is distributed to each building, the problem becomes one of how best to circulate the thermal energy within the building. There are many potential configurations which could be used. The basic design assumed to be most applicable for the garden apartment building model is a two-pipe hydronic distribution system with a split or double fan coil located in each apartment, as shown in Fig. 6.1.

The district HVAC system design is based on the following conditions:

Hot water temperatures:

$$
\text { Entering }-141^{\circ} \mathrm{C}\left(285^{\circ} \mathrm{F}\right)
$$

Leaving $-102^{\circ} \mathrm{C}\left(215^{\circ} \mathrm{F}\right)$

Chilled water temperatures:

$$
\begin{aligned}
& \text { Entering }-6^{\circ} \mathrm{C}\left(43^{\circ} \mathrm{F}\right) \\
& \text { Leaving }-14^{\circ} \mathrm{C}\left(58^{\circ} \mathrm{F}\right)
\end{aligned}
$$

Circulating water in building pipes:

$$
0.2-1.2 \mathrm{~m} / \mathrm{s}(0.5 \text { to } 4 \mathrm{fps})
$$

Hot water is provided by installing a heat exchanger and central storage tank in the basement where the entering $141^{\circ} \mathrm{C}\left(285^{\circ} \mathrm{F}\right)$ water can heat potable water to $66^{\circ} \mathrm{C}\left(150^{\circ} \mathrm{F}\right)$. A separate piping system is installed to distribute the domestic hot water to each apartment.

A list of the district system HVAC building equipment and the estimated installation cost for a two-story garden apartment is shown III Table 6.2. The total installed cost is estimated at $\$ 1,835$ per apartment. This rnst does not include any kind of energy measuring meter for individual apartment billing purposes. An energy meter consisting of a flow meter and two resistance thermocouples for measuring the temperature difference between the incoming and returning water and wiring to a central processing point for summing energy consumption over time is believed to cost around $\$ 250$ each.

The costs for ducting and building space are not included since the costs which are common to all types of HVAC systems are neglected. The primary objective is to determine comparative differences rather than absolute cost estimates of installing complete HVAC systems. 


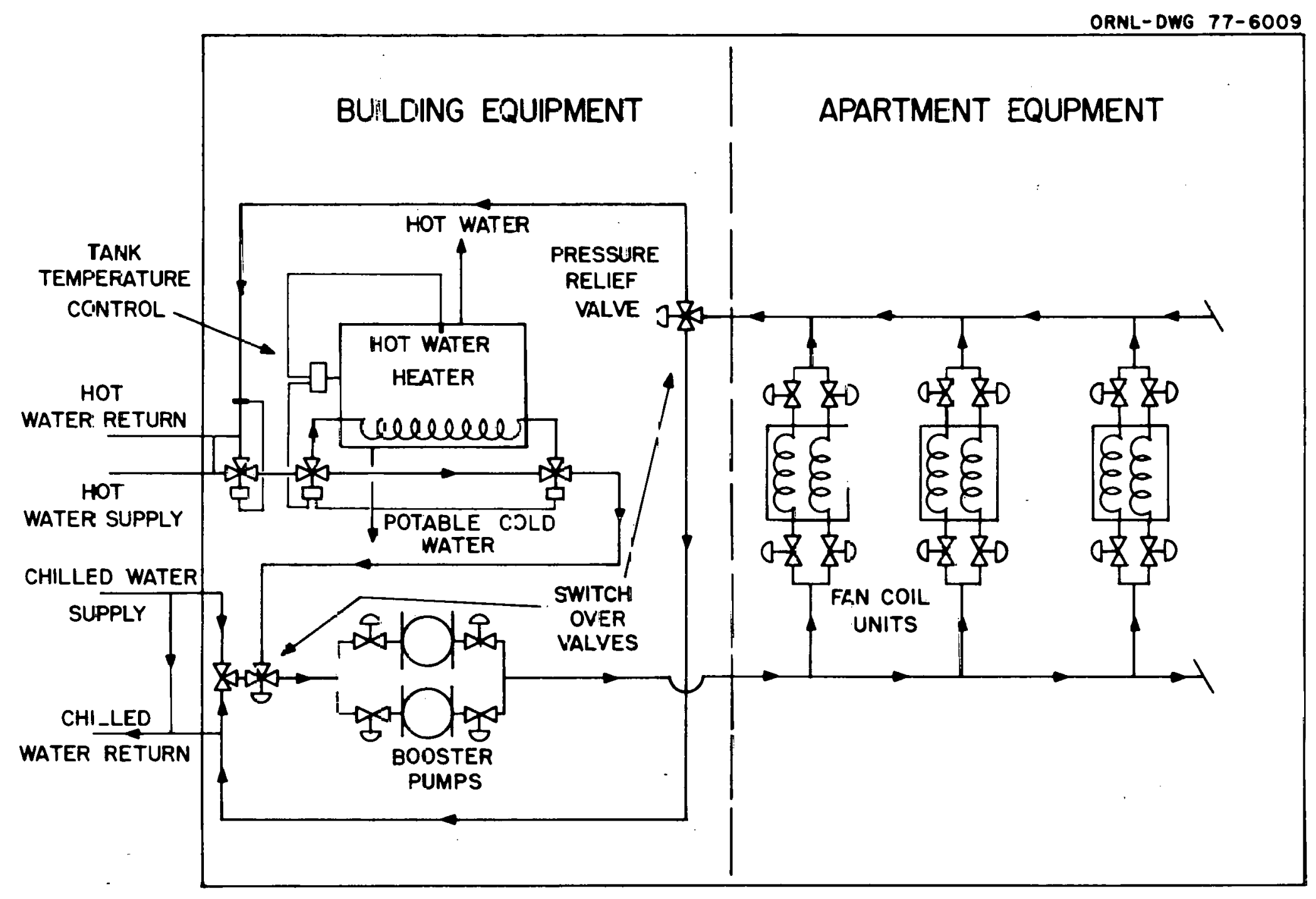

Fig. 6.1. Twa-pipe hydronic distribution system for district heating model. 
Table 6.2. District system two-story garden apartment building HVAC equipment costs

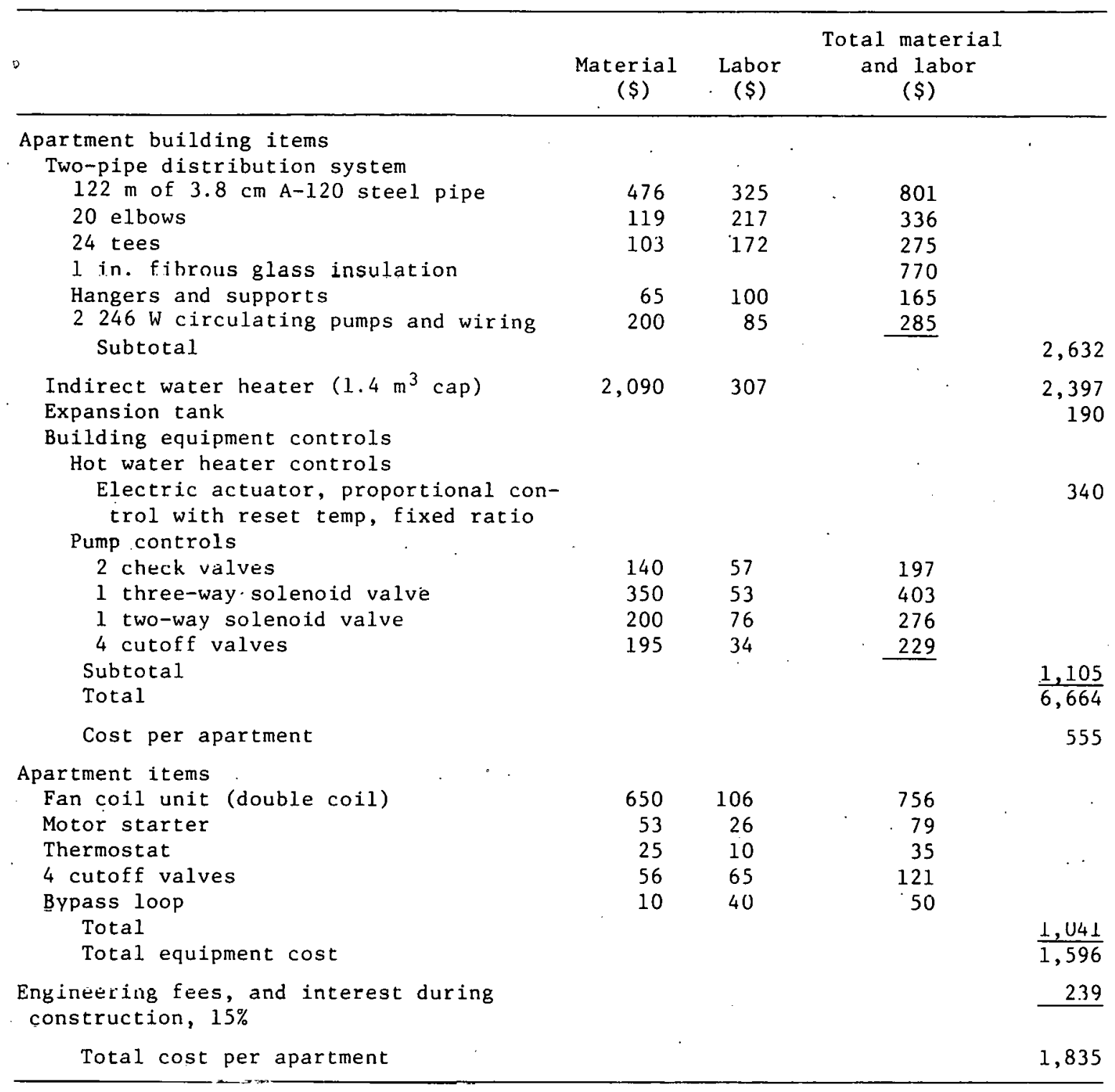

Building equipment.--For cost purposes, A-120 steel pipe is assumed since the design rirrulating water temperature exceeds $121^{\circ} \mathrm{C}\left(250^{\circ} \mathrm{F}\right)$. The thermoplastic materials are generally limited to hot water temperatures below $93^{\circ} \mathrm{C}\left(200^{\circ} \mathrm{F}\right.$ ) and pressures below $689.5 \mathrm{kPa}$ (100 psig).

The average size pipe assumed adequate to meet peak cooling loads for the garden apartment models is $38 \mathrm{~mm}$ ( 1 l/2 in.). This estimate is based on a maximum allowed water velocity of $1.2 \mathrm{~m} / \mathrm{s}$ ( $4 \mathrm{fps}$ ). Velocities 
greater than $1.5 \mathrm{~m} / \mathrm{s}$ ( $5 \mathrm{fps}$ ) are believed to cause air pockets in the distribution system resulting in undesirable noise (i.e. water hammer).

All of the distribution piping is insulated with $25 \mathrm{~mm}$ ( 1 in.) of preformed fibrous glass finished with a fire retardant foil and white kraft jacket. The cost of insulation shown in Table 6.2 is based on an average standard unit price for the continental United States for projects having more than $\$ 30,000$ of insulation.

Two $(0.373 \mathrm{~kW})$ circulating booster pumps are required to circulate the space conditioning water. Two pumps are installed to provide backup capacity in case one of the pumps fails to operate.

The hot water heater is sized according to a report by $\mathrm{R}$. G. Werden and L. G. Spielvogel. 41

The indirect storage water heater shown in Fig. 6.2 (Ref. 42) is designed primarily for service conditions where the hot water requirements are not constant or when a large volume of heated water must be held in storage to provide for periods of peak load. When the heater is in use, cold water enters the storage tank beneath the heating coil, and, as it absorbs heat, it gradually rises by natural convection to the upper portion of the tank, where it may be drawn. nff. The tank heating coil con sists of a number of $U$-shaped tubes which are attached to a tube sheet. The coll is inserted into the tank through a flanged npening to whioh the coil and bonnet are securely attached. The hot water is circulated through the tubes of the coil to transfer heat to the water in the tank. Tho tank coil is made of stainless steel tubing since copper can only be used up to $121^{\circ} \mathrm{C}\left(250^{\circ} \mathrm{F}\right)$. The storage tank is made of galvanized carbon steel and is constructed to withstand $7756 \mathrm{kPa}$ (125 psi) working pressure.

The expansion tank takes up the expansion of water, which at the time is used for pressurizing the system.

'l'he increase in vulume of the water located within the building distribution system from $4^{\circ} \mathrm{C}\left(40^{\circ} \mathrm{F}\right)$ to $141^{\circ} \mathrm{C}\left(285^{\circ} \mathrm{F}\right)$ is about $8 \% .42$

The water heater is controlled by providing variable water flow through the immersed heat exchanger (see Fig. 6.1). A bypass is provided and two 2-way valves are controlled by a resistance thermostat immersed towards the top of the water storage tank. When the hot water heater 
ORNL-DWG 77-1988

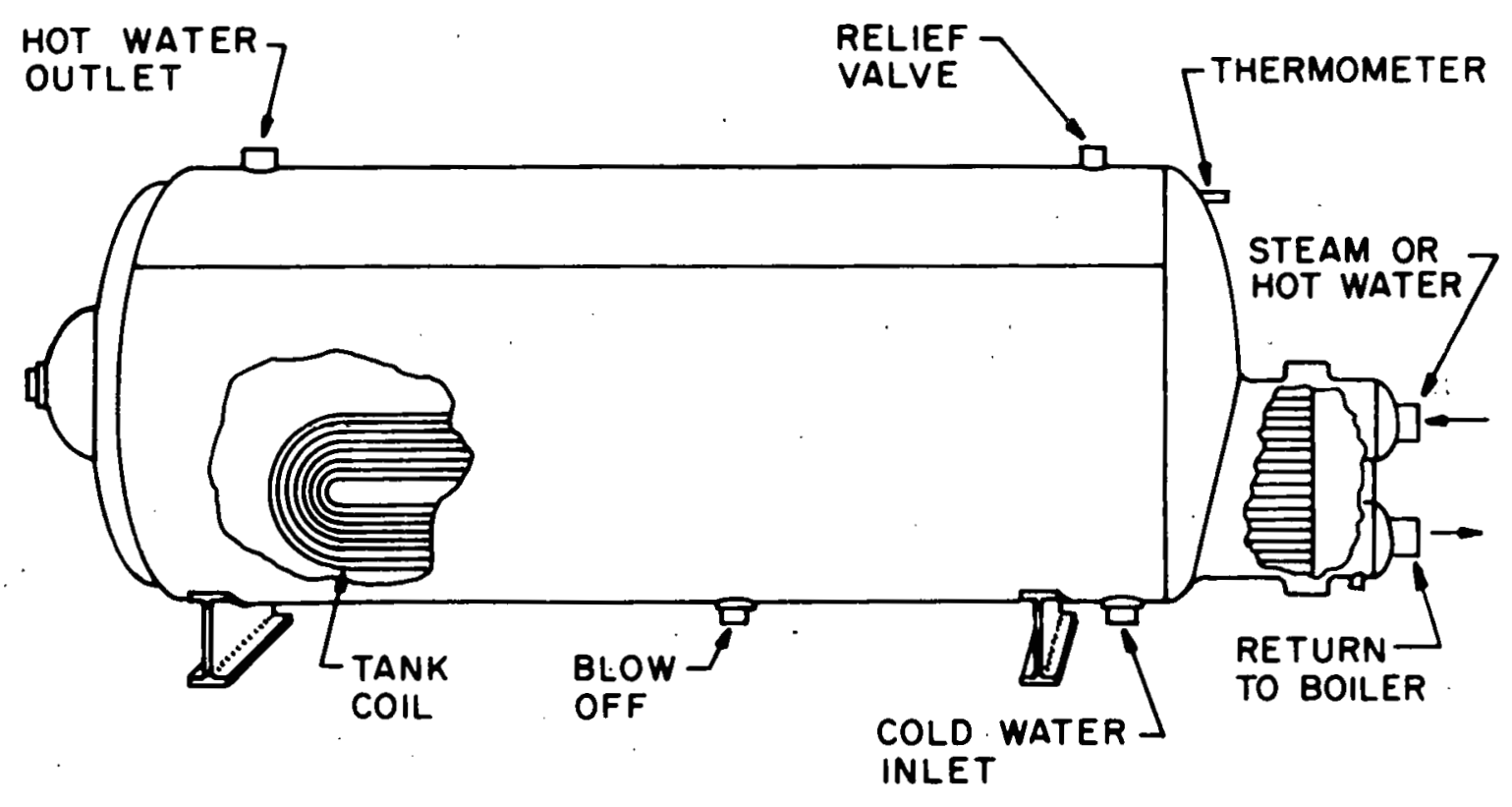

Fig. 6.2. Indirect water heater (horizontal type). 
reaches a certain maximum temperature, the two 3-way solenoid valves are reset to bypass the incoming hot water from the central distribution system. When the hot water falls below a set minimum temperature, the resistance thermostat commands the solenoid controlled 3-way valves to switch back to circulating the incoming hot water through the heat exchanger.

All booster pumps are equipped with check valves at the discharge to prevent excessive startup load and reverse flow through the pump under nonoperating conditions. The pumps are intermittently operated and a 3 -way valve varies the flow of water from the main distribution line (see Fig. 6.1).

Individual apartment items.--The fan coil units selected for this system consist of two separate coils, one for heating and the other for cooling and dehumidifying (see Fig. 6.1). The basis for selecting a double or split coil over a single coil used for both heating and cooling is the enhanced controllability of the split coil unit.

The cooling coil must provide both cooling and dehumidifying, thus it is very important that the proper amount of surface area be installed to obtain the ratio of air side sensible-to-total heat which is required for maintaining the air dry bulb and wet bulb temperatures in the conditioned space. 'l'his requires a larger coil than is optimum for heating with $285^{\circ} \mathrm{F}$ entering water and $102^{\circ} \mathrm{C}\left(214^{\circ} \mathrm{F}\right)$ leaving water.

Cost sensitivity.--Four-pipe distribution system - Installing a fourpipe distribution system, which allows one apartment to be heating while another in the same building is cooling, would cost an additional $\$ 200$ pe's apariment.

Climate - The different heating and cooling design loads result in such small differences in required fan coil size that the costs shown in Table 6.2 represent the cost of this system for apartments within the range of design loads of interest.

Apartment building - The district system HVAC installed cost for a single story consumer garden apartment consisting of six apartments is estimated at about $\$ 2,116$ per apartment. The $16 \%$ increase over the same system installed in a two-story apartment building is due primarily to 
the smaller number of apartments paying for essentially the same control system.

The same district HVAC system installed in a three-story consumer garden apartment building consisting of 18 apartments is estimated at about $\$ 1,690$ per apartment.

Central building equipment system

The reference central building equipment model selected for comparing performance and cost with the district system, using thermal energy from a nuclear power plant, consists of a central boiler located in the basement for heating both domestic water and water for space heating. The apartments are cooled by individual electric air-conditioning units.

The central building equipment and the estimated installation cost for a two-story garden apartment in Philadelphia is shown in Table 6.3. The total estimated cost for the HVAC system is $\$ 2,499$. The estimate is actually not a complete cost since items which are common to all HVAC systems to be compared are not included. Also, the costs shown in Table 6.3 do not include the cost of energy meters for billing thermal energy consumption.

Building equipment.--The building equipment for this model is the same as described for the district system shown in Fig. 6.1, except that an electric hydronic boiler is added to serve as a heat source. During the cooling season, no water need be circulated since individual apartment air conditioners satisfy the space cooling loads.

Figure 6.3 shows the material and installation cost for a range of electric bollers from 5.6 to $146 \mathrm{~kJ} / \mathrm{s}(20,000$ to $525,000 \mathrm{Btu} / \mathrm{hr})$ water. heating capacity. ${ }^{3}$ The electric boilers selected for this design are conventional packaged boilers having all components, including immersed electric resistance heaters, controls, and auxiliary equipment. Under favorable conditions at gross output ratings, electric boilers of this type have efficiencies ranging from $90 \%$ to $99 \%$. The minimum depreciation period for a boiler is believed to be about 20 years. 42 
Table 6.3. Central building equipment model costs for the two-story garden apartment building located in Philadelphia

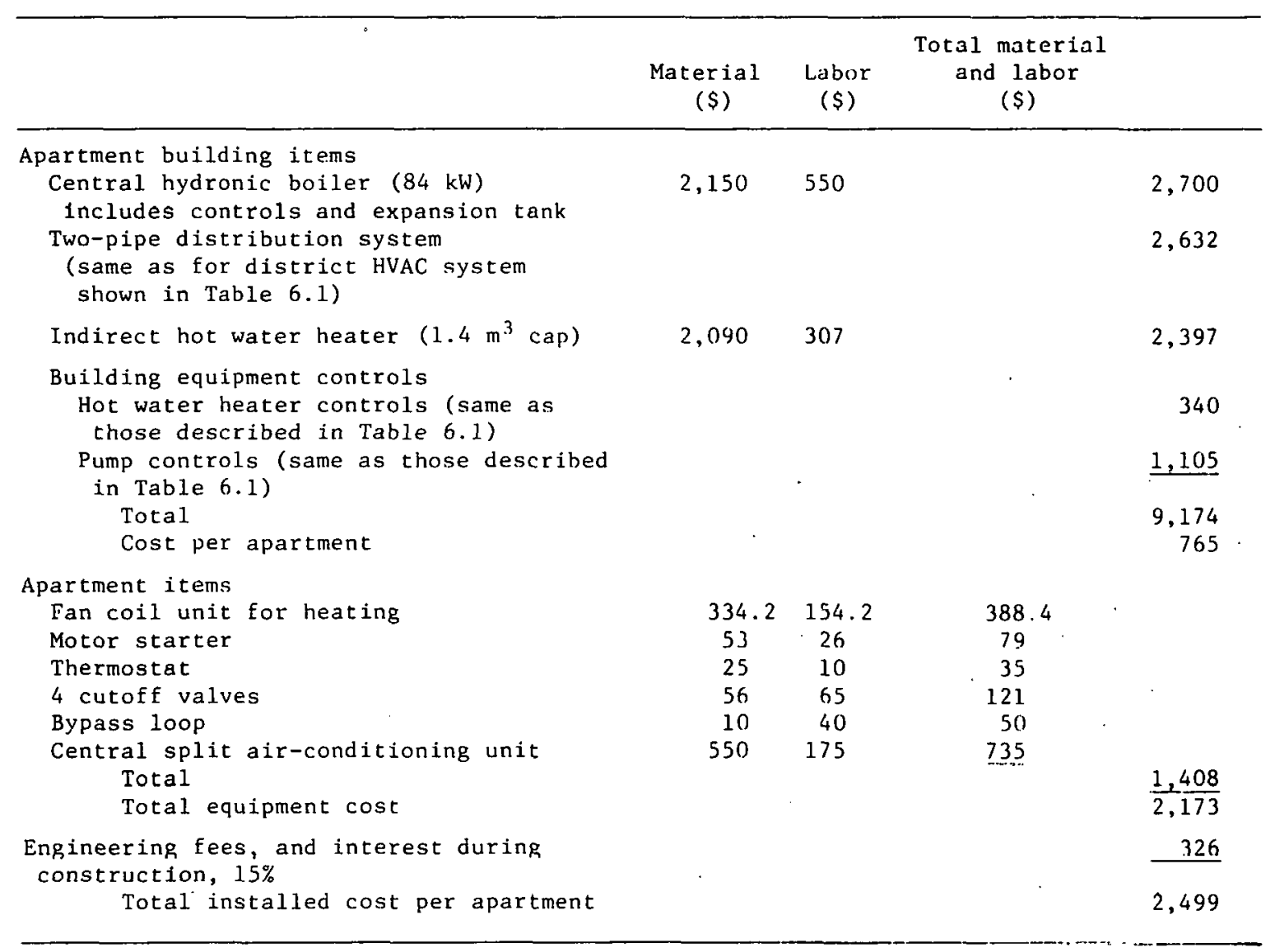

Apartment items.--Fan coil units with a single coil are installed in each apartment for distributing heat. The indoor evaporator coil for the central air conditioner is installed in the same duct as the heating coil and a common fan is used for both heating and cooling.

Each apartment has its own central air-conditioning unit. The condenser and compressor are installed either on the roof or on a concrete pad near each apartment. The cooling capacity for each unit is 5.9 to $6.4 \mathrm{~kJ} / \mathrm{s}(21,000$ to 23,000 Btu/hr) with an Air Conditioning and Refrigeration Institute (ARI) energy efficiency ratio (EER) rating of about 8 .

Cost sensitivity.--C1imate - Since the heat source for this HVAC system is included in the building equipment, some difference in cost results 


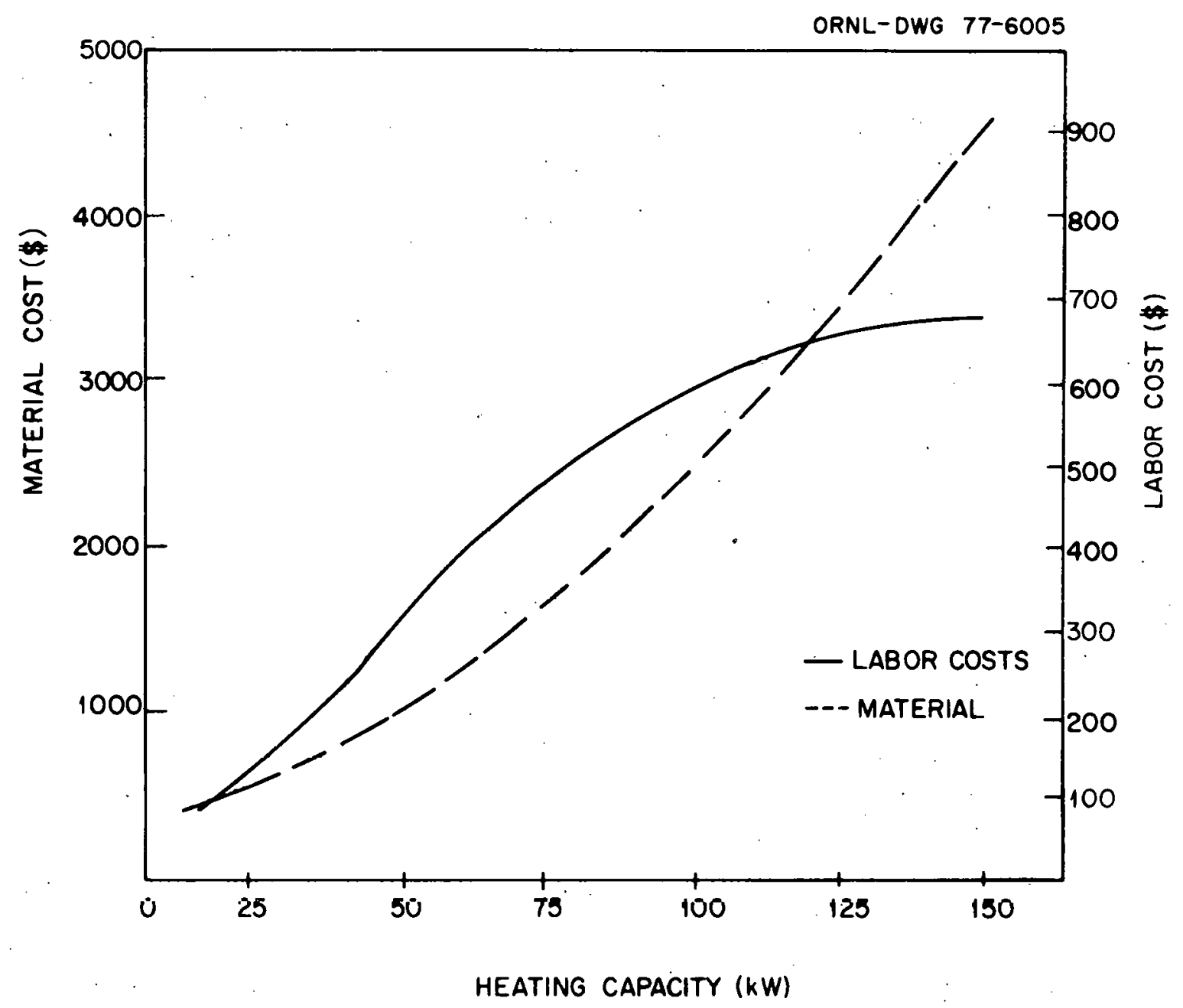

Fig. 6.3. Electric hot water boiler material and labor installation cost. 
from the various design heating loads in climates other than Philadelphia.

If the same HVAC system and two-story garden apartment were located in Minneapolis, the higher design heating load of $8.4 \mathrm{~kJ} / \mathrm{s}$ per apartment $(30,000 \mathrm{Btu} / \mathrm{hr}$ per apartment) compared to $6.7 \mathrm{~kJ} / \mathrm{s}$ per apartment $(24,000$ Btu/hr per apartment) in Philadelphia would require a larger boiler, resulting in an additional cost of about $\$ 70$ per apartment.

Apartment building - The central HVAC building equipment model installed in a single-story apartment building with six reference apartments is estimated to have an installed cost of about $\$ 2,680$ per apartment. The same central system installed in a three-story garden apartment building with 18 dwelling units is estimated to cost about $\$ 2,440$ per apartment.

Alternate heat source - Because the HVAC system cost in Table 6.3 is based on an electric boiler, the use of a gas or oil boiler will result in cost difference. Figure 6.3 presents installed costs for oil and gas boilers as a function of heating capacity.

If the HVAC system in Philadelphia used an oil boiler instead of the electric boiler, the installed cost of the HVAC system would decrease by about $\$ 20$ per apartment. This includes the difference in boiler costs and a $15 \%$ allowance for engineering fees and interest during construction. Substitution of a gas fired boiler would not affect the HVAC installed cost.

Installed HVAC system costs developed for the apartment complex were assumed to be applicable to the commercial sector and were used for purposes of estimating the commercial sector breakeven costs.

\section{Residential-Commercial Heating Breakeven Economics}

\section{Multifamily residential-commercial sector}

The commercial-multifamily residential breakeven cost analysis was performed using the HVAC system costs from Tables 6.2 and 6.3 and the installed boiler costs from Figs. 6.3 and 6.4 . The district heating system was not compared to building systems that utilized individual 


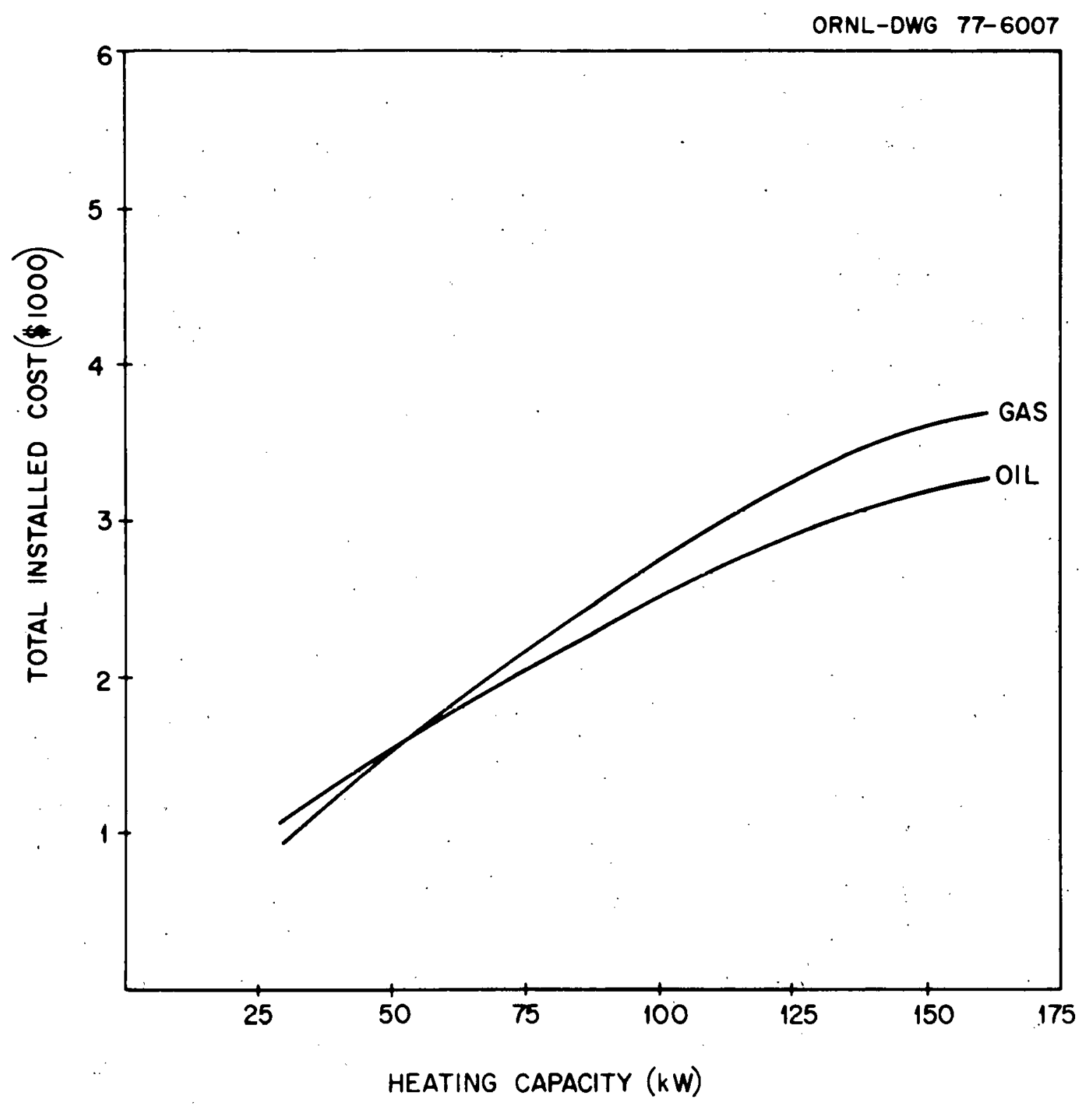

Fig. 6.4. Installed boiler cost for gas and oil fired systems. 
apartment systems because the additional cost to install a central duct system was prohibitive.

The breakeven costs for heat from the thermal grid were calculated by taking the difference between the costs of the district system model and the central building equipment model that were attributable to the heating system. This capital cost difference was then annualized and converted to a unit heat cost by dividing the annualized cost by the total yearly heating load. The breakeven district heating cost, for a new installation, was then determined by adding the capital related unit heat cost to the fuel cost. For retrofit applications the unit heat rnst ditference attributable to capital items was zero because the two systems used essentially the same distribution network within the building. Therefore, the breakeven price for a retrofit application is equal to the fuel charge.

It should be remembered that this analysis only applies to buildings with central ductwork or hot water distribution systems. For other systems the additional required internal distribution system renders these applications economically infeasible.

Figure 6.5 contains the installed building equipment cost difference between the central building system and district heating cases for various climates, fuels, and building heights. These cost differences are those attributable to the heating system. From Fig, 6.5 it is evident that the system using heat from the thermal grid is less expensive to install in the building. This is because both systems utilize the same building distribution network but the district heating system does not require a boiler.

As shown in Table 6.4, the fuel charges for the central building equipment system account for the fuel price and the boiler efficiency. l'he tuel prices in Table 6.4 correspond to prices of $\$ 132 / \mathrm{m}^{3}$ ( $\left.\$ 0.50 / \mathrm{gal}\right)$ for fuel oil, $\$ 0.04 / \mathrm{kW}-\mathrm{hr}$ for electricity and $\$ 51.20 / 10^{3} \mathrm{~m}^{3}\left(\$ 1.45 / 10^{3}\right.$ $\mathrm{ft}^{3}$ ) for natural gas.

In annualizing the capital cost difference a fixed charge rate of $20 \%$ was used. This fixed charge rate is typical for a real estate developer. 


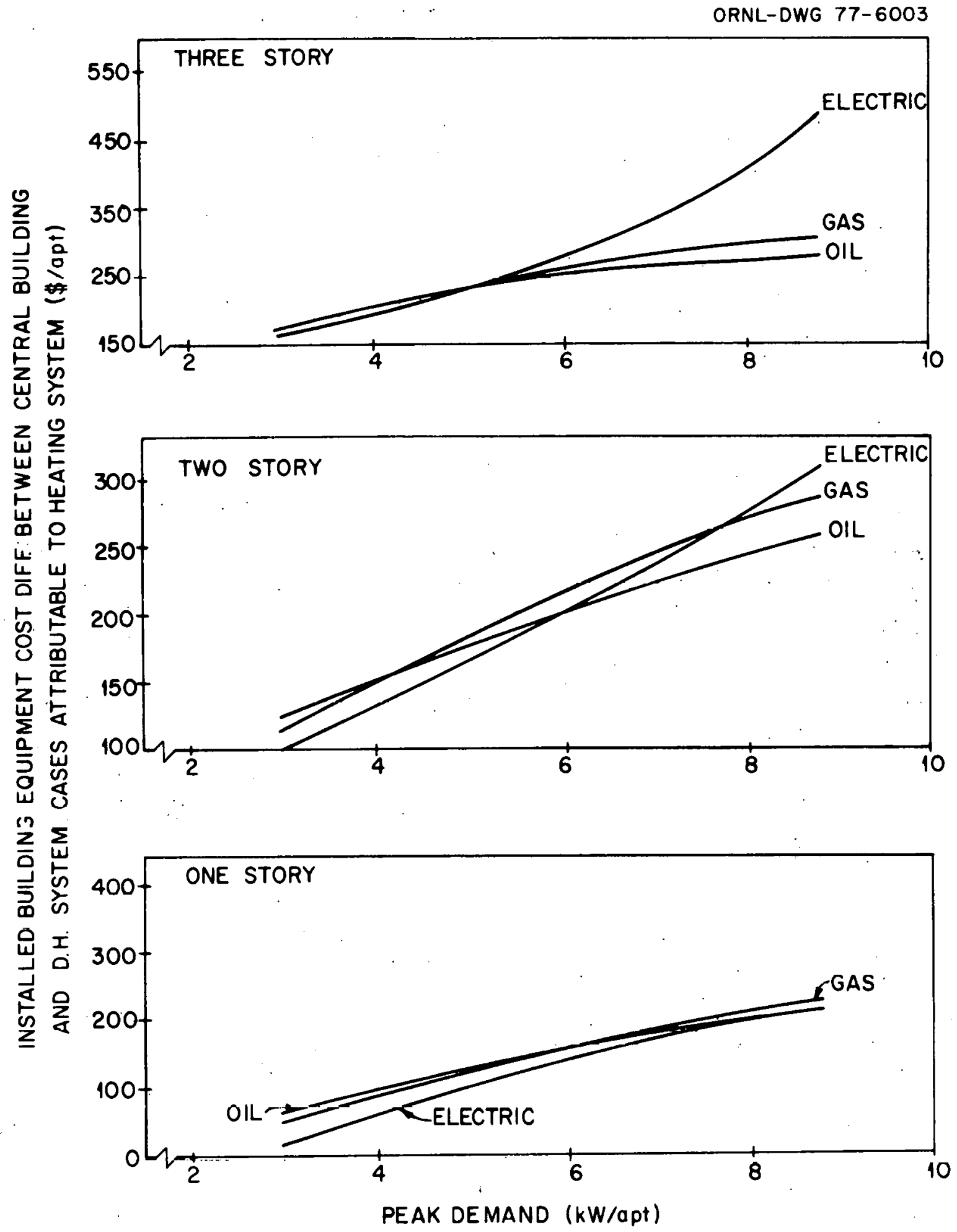

Fig. 6.5. Capital cost difference between district heat and conventional heating for garden apartments. 
Table 6.4. Fuel charges for central building equipment system

\begin{tabular}{lccc}
\hline & Price & $\begin{array}{c}\text { Boiler } \\
\text { efficiency }\end{array}$ & Fuel charge \\
\cline { 2 - 4 } & $(\$ / G J)$ & $(\%)$ & $\begin{array}{r}(\$ / G J \text { of } \\
\text { heating })\end{array}$ \\
\hline Electricity & 11.72 & 100 & 11.72 \\
Gas & 1.45 & 60 & 2.42 \\
Oil & 3.52 & 55 & 6.40 \\
\hline
\end{tabular}

In computing the breakeven costs for new applications it was assumed that the buildings would be constructed in accordance with the 1976 updated HUD standards. The design loads and yearly energy use information for the selected cities is given in Table 5.5 for these construction standards. The breakeven price for heat from the thermal grid is shown in Table 6.5 for the selected sites. It is evident from Table 6.5 that the major portion of the breakeven cost is attributable to the cost of fuel. Therefore, district heat will be most competitive with systems that are subject to high fuel charges, such as electric or oil-fired boilers.

As stated previously, the breakeven price for heat from the thermal grid for retrofit applications is equal to the fuel charge. Therefore, the breakeven price for retrofit applications is equal to the fuel charges presented in Table 6.4 for the alternate systems considered.

\section{Single family sector}

The breakeven price analysis for the single family sector compared the use of heat from the thermal grid to several conventional systems. It was assumed that heat from the grid was used to satisfy space heating and hot water demands. The alternate conventional systems considered included: gas-tired space and water heating, oil-tired space heat with oil or electric hot water heating, and all electric systems using resistance heaters and heat pumps. 
Table 6.5. Breakeven price for thermal grid heat at selected sites for new applications

\begin{tabular}{|c|c|c|c|}
\hline \multirow[t]{2}{*}{ City/building } & \multicolumn{3}{|c|}{$\begin{array}{c}\text { Breakeven cost for } \\
\text { indicated fuel } \\
(\$ / G J)\end{array}$} \\
\hline & Electric & Oil & Gas \\
\hline \multicolumn{4}{|l|}{ Philadelphia } \\
\hline One story & 11.97 & 7.81 & 2.86 \\
\hline Two story & 12.44 & 7.24 & 3.23 \\
\hline Three story & 12.85 & 7.59 & 3.61 \\
\hline \multicolumn{4}{|l|}{ Atlanta } \\
\hline One story & 13.03 & 7.81 & 3.83 \\
\hline Two story & 12.62 & 7.43 & 3.45 \\
\hline Three story & 12.13 & 7.09 & 3.04 \\
\hline \multicolumn{4}{|l|}{ Chicago } \\
\hline One story & 12.15 & 6.99 & 3.01 \\
\hline Two story & 12.53 & 7.29 & 3.31 \\
\hline Three story & 12.91 & 7.59 & 3.61 \\
\hline \multicolumn{4}{|l|}{ Minneapolis } \\
\hline One story & 12.16 & 6.91 & 2.93 \\
\hline Two story & 12.48 & 7.20 & 3.26 \\
\hline Three story & 12.79 & 7.47 & 3.49 \\
\hline \multicolumn{4}{|l|}{ Dallas } \\
\hline One story & 12.10 & 7.09 & 3.00 \\
\hline Two story & 12.68 & 7.48 & 3.50 \\
\hline Thiree story & 13.10 & 7.94 & 3.96 \\
\hline
\end{tabular}

Breakeven prices were estimated for new and retrofit applications. The costs used in these calculations include: (A) space heating and hot water energy costs associated with conventional systems, (B) the unit annualized cost associated with conventional equipment replaced when thermal grid heat is utilized, and (C) the unit annualized cost associated with the additional equipment required to utilize heat from the grid. The retrofit breakeven price was calculated by subtracting the additional equipment cost from the energy cost $(A-C)$. The breakeven price for new applications was estimated by adding the replaced equipment cost to the retrofit breakeven price $(A+B-C)$. 
The cost for equipment to utilize heat from the grid (C) is summarized in Table 6.6. The piping costs were based on the assumptions that the supply and return lines, from the thermal grid to the home, are $6.1 \mathrm{~m}$ $(20 \mathrm{ft})$ long and includes the piping within the house to the fan coil unit. This cost was annualized using a fixed charge rate which is typical for a home owner and includes annual maintenance costs and consideration of the type of equipment used. This annual cost was then converted to a unit cost by dividing by the total energy use for the selected site.

Table 6.6. Cost eetimateo for equipment necessary

for the homeowner to utilize heat

from the thermal grid

\begin{tabular}{lc}
\hline \multicolumn{1}{c}{ Item } & Installed cost (\$) \\
\hline Heating coil & 70 \\
Blower & 65 \\
Proportioning control valve & 100 \\
Piping $\quad \underline{290}$ \\
$\quad$ Total & 525 \\
\hline
\end{tabular}

Space heat and hot water energy costs and the annualized cost of replaced equipment were based on data in Ref. 43 and 44 . These costs are based on heating needs of a $167 \mathrm{~m}^{2}$ (1800 $\mathrm{ft}^{2}$ ) home constructed according to the $1976^{\circ}$ HUD standards. Ihe utility (gas, electricity) rates used were the actual rates in the various locations in early 1975. The fixed charge rates on the home heating system ranged from 14 to $16 \%$ depending on the equipment replaced.

The breakeven prices for heat from the thermal grid are presented in Table 6.7 through 6.11 for the selected cities. It is evident from these tables that new applications present the best opportunity for use of thermal grid heat, especially when oil or electric systems are under consideration. 
Table 6.7. Breakeven price for heat from the thermal grid for Philadelphia for single family residence

\begin{tabular}{|c|c|c|c|c|c|}
\hline \multirow[b]{2}{*}{ - System } & \multirow{2}{*}{$\begin{array}{c}\text { Energy cost for } \\
\text { heat and hot water } \\
(\$ ; G J)\end{array}$} & \multirow{2}{*}{$\begin{array}{c}\text { Replaced equipment } \\
\text { cost } \\
(\$ / G J)\end{array}$} & \multirow{2}{*}{$\begin{array}{l}\text { Additional } \\
\text { equipment cost } \\
(\$ / G J)\end{array}$} & \multicolumn{2}{|c|}{ Breakeven price } \\
\hline & & & & $\begin{array}{l}\text { Replacement } \\
(\$ / G J)\end{array}$ & $\begin{array}{l}\text { New } \\
(\$ / G J)\end{array}$ \\
\hline $\begin{array}{l}\text { Gas heat and } \\
\text { hot water }\end{array}$ & 3.91 & 1.27 & 1.27 & 2.64 & 3.91 \\
\hline $\begin{array}{l}\text { Oil heat and oil hot } \\
\text { water }\end{array}$ & 6.40 & 1.64 & 1.27 & 5.13 & 6.77 \\
\hline $\begin{array}{l}\text { Oil heat and electric } \\
\text { hot water }\end{array}$ & 8.29 & 1.64 & 1.27 & 7.02 & 8.66 \\
\hline $\begin{array}{l}\text { All electric - } \\
\text { resistance heat }\end{array}$ & 8.58 & 1.22 & 1.27 & $7.31^{\circ}$ & 8.53 \\
\hline $\begin{array}{l}\text { All electric - heat } \\
\text { pump }\end{array}$ & 5.48 & 2.50 & 1.27 & 4.21 & 6.71 \\
\hline
\end{tabular}


Table 6.8. Breakeven price for heat from the thermal grid for Atlanta for single family residence

\begin{tabular}{|c|c|c|c|c|c|}
\hline \multirow{2}{*}{ System } & \multirow{2}{*}{$\begin{array}{l}\text { Energy cost for } \\
\text { heat and hot water } \\
(\$ / G J)\end{array}$} & \multirow{2}{*}{$\begin{array}{c}\text { Replaced equipment } \\
\text { cost } \\
(\xi / G J)\end{array}$} & \multirow{2}{*}{$\begin{array}{l}\text { Additional } \\
\text { equipment cost } \\
(\$ / G J)\end{array}$} & \multicolumn{2}{|c|}{ Breakeven price } \\
\hline & & & & $\begin{array}{l}\text { Replacement } \\
\quad(\$ / G J)\end{array}$ & $\begin{array}{l}\text { New } \\
(\$ / G J)\end{array}$ \\
\hline $\begin{array}{l}\text { Gas heat and } \\
\text { hot water }\end{array}$ & 2.45 & 1.42 & 1.42 & 1.03 & 2.45 \\
\hline $\begin{array}{l}\text { Oil heat and oil hot } \\
\text { water }\end{array}$ & 6.40 & 1.84 & 1.42 & 4.98 & 6.82 \\
\hline $\begin{array}{l}\text { Oil heat and electric } \\
\text { hot water. }\end{array}$ & 7.35 & 1.84 & 1.42 & 5.93 & 7.77 \\
\hline $\begin{array}{l}\text { All electric - } \\
\text { resistance heat }\end{array}$ & 8.45 & 1.56 & 1.42 & 7.03 & 8.59 \\
\hline $\begin{array}{l}\text { A11 electric - heat } \\
\text { pump }\end{array}$ & 5.59 & 3.09 & 1.42 & 4.17 & 7.26 \\
\hline
\end{tabular}


Table 6.9. Braakeven price for heat from the thermal grid for Chicago for single family residence

\begin{tabular}{|c|c|c|c|c|c|}
\hline \multirow{2}{*}{ System } & \multirow{2}{*}{$\begin{array}{l}\text { Energy cost fc.r } \\
\text { heat and hot water } \\
(\$ / G J)\end{array}$} & \multirow{2}{*}{$\begin{array}{c}\text { Replaced equipment } \\
\text { cost } \\
(\$ / G J)\end{array}$} & \multirow{2}{*}{$\begin{array}{l}\text { Additional } \\
\text { equipment cost } \\
(\$ / G J)\end{array}$} & \multicolumn{2}{|c|}{ Breakeven price } \\
\hline & & & & $\begin{array}{l}\text { Replacement } \\
(\$ / G J)\end{array}$ & $\begin{array}{l}\text { New } \\
(\$ / G J)\end{array}$ \\
\hline $\begin{array}{l}\text { Gas heat and } \\
\text { hot water }\end{array}$ & 2.70 & 1.00 & 0.95 & 1.75 & 2.75 \\
\hline $\begin{array}{l}\text { Oil heat and oil hot } \\
\text { water }\end{array}$ & 6.40 & 1.29 & 0.95 & 5.45 & 6.74 \\
\hline $\begin{array}{l}\text { Oil heat and electric } \\
\text { hot water }\end{array}$ & 6.01 & 1.29 & 0.95 & 5.06 & 6.35 \\
\hline $\begin{array}{l}\text { All electric - } \\
\text { resistance heat }\end{array}$ & 4.52 & 1.03 & 0.95 & 3.57 & 4.52 \\
\hline $\begin{array}{l}\text { All electric - heat } \\
\text { pump }\end{array}$ & 2.83 & 2.17 & 0.95 & 1.88 & 4.05 \\
\hline
\end{tabular}


Table 6.10. Breakeven price for heat from the thermal grid for Minneapo-is for singile family residence

\begin{tabular}{|c|c|c|c|c|c|}
\hline \multirow[b]{2}{*}{ System } & \multirow{2}{*}{$\begin{array}{l}\text { Energy cost for } \\
\text { heat and hot water } \\
(\$ / G J)\end{array}$} & \multirow{2}{*}{$\begin{array}{c}\text { Replaced equipment } \\
\text { cost } \\
(\$ / G J)\end{array}$} & \multirow{2}{*}{$\begin{array}{c}\text { Additional } \\
\text { ecuipment cost } \\
(\$ / G J)\end{array}$} & \multicolumn{2}{|c|}{ Breakeven price } \\
\hline & & & & $\begin{array}{l}\text { Replacement } \\
\quad(\$ / G J)\end{array}$ & $\begin{array}{c}\text { New } \\
(\$ / G J)\end{array}$ \\
\hline $\begin{array}{l}\text { Gas heat and } \\
\text { hot water }\end{array}$ & 2.60 & 0.88 & 0.84 & 1.76 & 2.64 \\
\hline $\begin{array}{l}\text { Oil heat and oil hot } \\
\text { water }\end{array}$ & 6.40 & 1.13 & 0.84 & 5.56 & 6.69 \\
\hline $\begin{array}{l}\text { Oil heat and electric } \\
\text { hot water }\end{array}$ & 6.83 & 1.13 & 0.84 & 5.99 & 7.12 \\
\hline $\begin{array}{l}\text { All electric - } \\
\text { resistance heat }\end{array}$ & 6.33 & 0.94 & 0.84 & 5.49 & 6.43 \\
\hline $\begin{array}{l}\text { All electric - heat } \\
\text { pump }\end{array}$ & 4.70 & 1.94 & 0.84 & 3.86 & 5.80 \\
\hline
\end{tabular}


Table 6.11: Breakeven price for heat from the thermal grid for Dallas for single family residence

\begin{tabular}{lcccc}
\hline System & $\begin{array}{c}\text { Energy cost for } \\
\text { heat } \begin{array}{c}\text { anc hot water } \\
(\$ / G J)\end{array}\end{array}$ & $\begin{array}{c}\text { Replaced equipment } \\
\text { cost } \\
(\$ / G J)\end{array}$ & $\begin{array}{c}\text { Additional } \\
\text { equipment cost } \\
(\$ / G J)\end{array}$ & $\begin{array}{c}\text { Breakeven price } \\
\text { Replacement } \\
(\$ / G J)\end{array}$ \\
\hline $\begin{array}{l}\text { Gas heat and } \\
\text { hot water }\end{array}$ & 1.54 & 1.55 & 1.63 & -0.09 \\
$\begin{array}{l}\text { New } \\
\text { Oil heat and oil hot } \\
\text { water }\end{array}$ & 6.40 & 2.01 & 1.63 & 4.77 \\
$\begin{array}{l}\text { Oil heat and electric } \\
\text { hot water }\end{array}$ & 5.49 & 2.01 & 1.63 & 3.86 \\
$\begin{array}{l}\text { All electric }- \\
\text { resistance heat }\end{array}$ & 3.89 & 1.59 & 1.63 & 2.26 \\
$\begin{array}{l}\text { All electric }- \text { heat } \\
\text { pump }\end{array}$ & 2.23 & 3.40 & 1.63 & 5.87 \\
\hline
\end{tabular}




\section{Industrial Heat Supply Breakeven Economics}

Breakeven prices for the industrial subregion were computed for industries with steam usage rates of $63 \mathrm{~kg} / \mathrm{s}\left(0.5 \times 10^{6} \mathrm{lb} / \mathrm{hr}\right)$ to $252 \mathrm{~kg} / \mathrm{s}$ $\left(2.0 \times 10^{6} \mathrm{lb} / \mathrm{hr}\right)$. The industrial model used in developing the breakeven prices assumed that low pressure steam was generated for process use using fossil fuels.

An additional model was initially included. This model assumed that high pressure steam was produced and electricity was generated for use within the plant before the steam was utilized for process applications. A preliminary analysis of this situation indicated that in most rases the generating costs for this power was greater than the prevailing industrial rate for power purchased from the utility. For this reason further study of this model was not pursued.

It was assumed that the thermal grid distribution network delivered steam to the plant boundary. The cost for transporting the steam from the plant boundary to the internal plant distribution network was assumed to be the responsibility of the customer. The cost estimate for this additional piping is based on the industrial subregion distribution costs and is presented in Fig. 6.6. The cost estimates in Fig. 6.6 assume a fixed charge rate of $22.2 \%$ and a transport distance of $0.8 \mathrm{~km}$ ( $0.5 \mathrm{mile})$.

Fuel prices for the industrial sector were assumed to be equal to those presented in Sect. 4 for utilities. This assumption is probably reasonable for the larger $\left[126 \mathrm{~kg} / \mathrm{s}\left(1.0 \times 10^{6} \mathrm{lb} / \mathrm{hr}\right)\right.$ or 1 arger] units because unit train coal transportation costs would be applicable. For the smaller units [less than $\left.126 \mathrm{~kg} / \mathrm{s}\left(1.0 \times 10^{6} \mathrm{lb} / \mathrm{hr}\right)\right]$ the fuel costs for coal would probably be greater than those presented in Sect. 4 because of higher transportation costs. However, since the fuel cost for any application strongly depends on the fuel transportation distance, it was felt that the fuel prices from sect. 4 would be adequate for use in this analysis. If the fuel prices used in this report are in fact lower than those found in actual practice, the net effect will be to make the thermal grid more competitive. Essentially then, the use of fuel prices from Sect. 4 for the industrial sector represents a conservative assumption. 


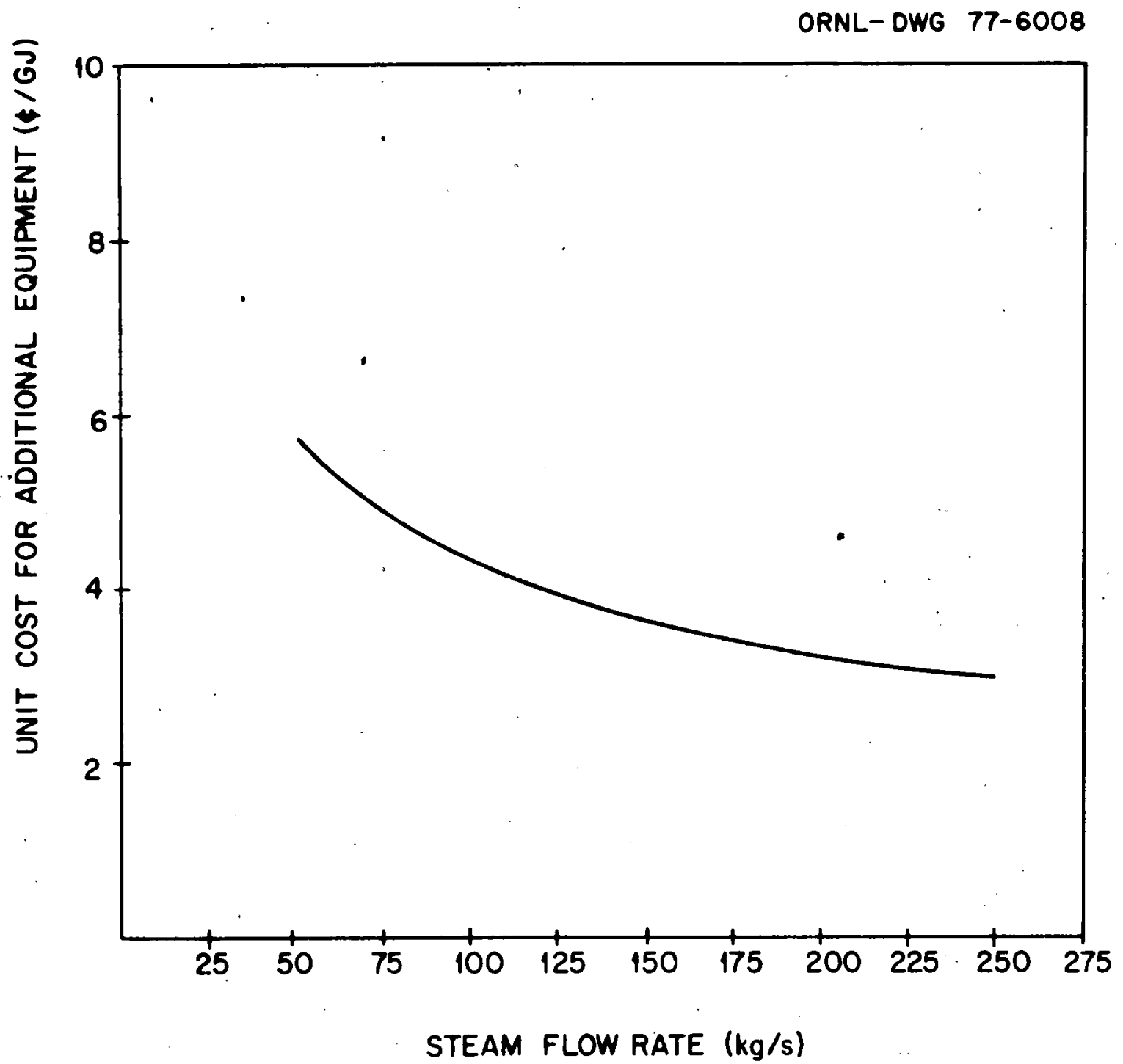

Fig. 6.6. Unit cost for additional equipment to utilize steam from thermal grid. 
It was assumed that the boiler produced saturated steam at $1620 \mathrm{kPa}$ (234 psig). Condensate is returned to the boiler at $121^{\circ} \mathrm{C}\left(250^{\circ} \mathrm{F}\right)$. The boiler efficiency was assumed to be $85 \%$ and a $90 \%$ capacity factor was used in the analysis. The fuel options examined were oil, natural gas, and high and low sulfur coal. The installed boiler costs and operating and maintenance costs presented in Table 6.12 were adapted from Ref. 5 . Surfur removal costs for high sulfur coal applications were adapted from Ref. 5. This added $48 \mathrm{c} / \mathrm{GJ}\left(48 \mathrm{c} / 10^{6} \mathrm{Btu}\right)$ to the cost of producing steam.

Table 6.12. Boiler capital and O\&M costs

\begin{tabular}{lccccc}
\hline & \multicolumn{5}{c}{ Fuel } \\
\cline { 2 - 6 } & High sulfur coal & Low sulfur coal & 011 & Gas \\
\hline $\begin{array}{c}\text { Installed cost } \\
\left(10^{3} \$ / \mathrm{kg} / \mathrm{s}\right)\end{array}$ & 214 & 214 & 159 & 127 \\
O\&M $\left(10^{3}\right.$ \$/year $)$ & 422 & 581 & 396 & 395 \\
\hline
\end{tabular}

In estimating the breakeven price for steam from the grid, capital cost items were annualized using a $22.2 \%$ fixed charge rate. This annualized cost was then added to the annual fuel charge and the operating and maintenance costs to yield a total annual cost. This annual cost was then converted to a net steam cost by dividing by the total annual energy use.

The breakeven prices presented in Table 6.13, for new applications were calculated by subtracting the additional equipment cost (for piping from the thermal grid substation to the industry) from the net steam cost. The breakeven prices for retrofit application were determined by subtracting the additional equipment cost from the fuel charge. The fuel charge was obtained by dividing the fuel price by the boiler efficiency.

It is cvident from Table 6.13 that new applications offer the most promising potential for use of steam from the grid. It is also evident that at the assumed price levels, the thermal grid would be most competitive with high sulfur coal and oil burning systems. 
Table 6.13. Breakeven prices for industrial subregion

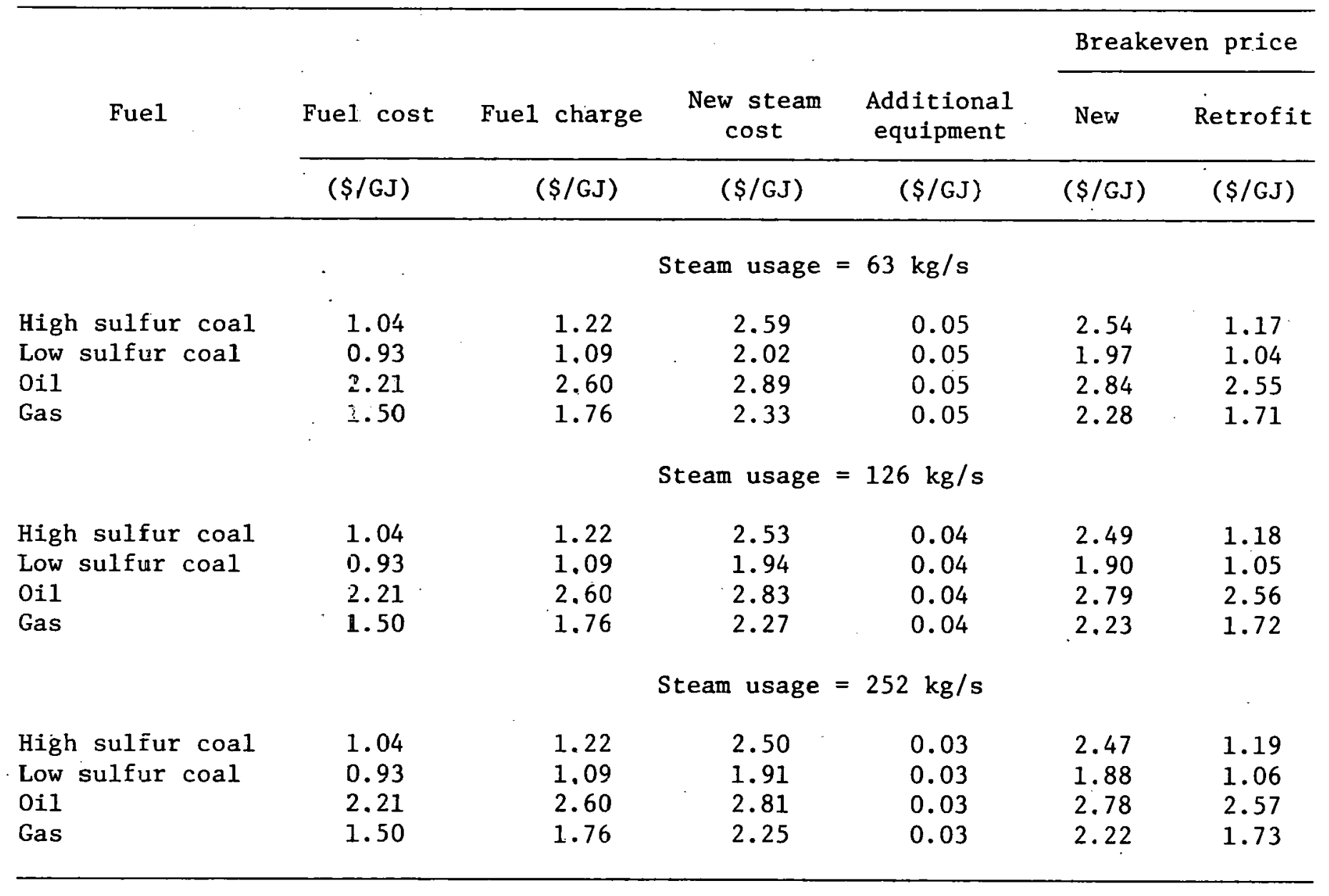




\section{$\underline{\text { Residential-Commercial Cooling Breakeven Economics }}$}

Breakeven prices for chilled water supply to the multifamily residential - commercial sector were computed for new and retrofit applications. The single family residence sector was not examined because chilled water distribution costs for this sector appeared prohibitive.

\section{$\underline{\text { New applications }}$}

Fur new applications the breakeven price calculations included the costs associated with the equipment required to utilize chilled waler from the grid and costs associated with conventional electrically driven air conditioning units.

The costs for the chilled water equipment was obtained from Tables 6.2 and 6.3. The difference between the two tuilding modcls is essentially the use of a split fan coil unit to use district chilled water. The cost for this item is $\$ 366$. Adding $15 \%$ to account for engineering fees and interest during construction yields a cost of $\$ 421$ for the equipment costs to utilize chilled water from the grid.

The alternative system considered was a split unit air conditioner. Since the peak cooling demand in the selected cities was fairly uniform, it was assumed that all sites would install the same sizc unit. From Table 6.3 the cost for this system (including engineering fees and interest) is $\$ 845$. In estimating the operating cost of the system, electricity costs were assumed to be $4 \mathrm{c} / \mathrm{kWhr}$ and an EER (energy efficiency rating) of 8 was used. This yielded an operating cost of $\$ 5.00 /$ C.J $\left(\$ 5.00 / 10^{6}\right.$ Btu $)$ of cooling.

Use of chilled water from the grid, therefore, results in a capital cost savings of $\$ 424$. Using a fixed charge rate of $20 \%$ results in an annual cost savings of $\$ 84.80$.

The annual cost savings and operating costs developed above were used in calculating the chilled water breakeven prices presented in Table 6.14. Since these calculations were for a new installation, the yearly cooling load estimates correspond to the new HUD standard figures shown in Table 5.10. 
Table 6.14. Chilled water breakeven prices for new applications

\begin{tabular}{lcccc}
\hline & $\begin{array}{c}\text { Yearly } \\
\text { cooling } \\
\text { load }\end{array}$ & $\begin{array}{c}\text { Unit } \\
\text { annual } \\
\text { capital } \\
\text { savings }\end{array}$ & $\begin{array}{c}\text { Fuel } \\
\text { cost }\end{array}$ & $\begin{array}{c}\text { Breakeven } \\
\text { price }\end{array}$ \\
\cline { 2 - 5 } & (GJ/apartment) & $(\$ / G J)$ & $(\$ / G J)$ & $(\$ / G J)$ \\
\hline Philadelphia & 13.2 & 6.42 & 5.00 & 11.42 \\
Atlanta & 17.5 & 4.85 & 5.00 & 9.85 \\
Chicago & 11.5 & 7.37 & 5.00 & 12.37 \\
Minneapolis & 9.7 & 8.74 & 5.00 & 13.74 \\
Dallas & 25.8 & 3.29 & 5.00 & 8.29 \\
\hline
\end{tabular}

\section{Retrof1t applications}

Retrofit applications will require a capital cost expense to install the second fan coil unit. Balanced against this will be the cost of electricity to operate the existing unit air conditioner. The additional capital cost for the second fan coil is the same as for the new application and represents an annual cost of $\$ 84.80$.

Since the air conditioner is an older unit, it was assumed that it had an EER of 5 . Therefore, with electricity at $4 \mathrm{c} / \mathrm{kWhr}$ the fuel charge fonr rnnling i.s $\$ 8.00 / G J\left(\$ 8.00 / 10^{6}\right.$ Btu $)$.

The chilled water breakeven prices for retrofit applications presented in Table 6.15 were obtained by subtracting the unit capital cost associated with the additional fan coil unit, from the fuel charge. The yearly cooling load estimates correspond to the 1971 HUD standard figures given in Table 5.10 . 
Table 6.15. Chilled water breakeven prices for retrofit applications

\begin{tabular}{lcccc}
\hline \multirow{2}{*}{ City } & $\begin{array}{c}\text { Yearly } \\
\text { cooling } \\
\text { load }\end{array}$ & $\begin{array}{c}\text { Unit } \\
\text { annual } \\
\text { capital } \\
\text { savings }\end{array}$ & $\begin{array}{c}\text { Fuel } \\
\text { cost }\end{array}$ & $\begin{array}{c}\text { Breakeven } \\
\text { price }\end{array}$ \\
\cline { 2 - 5 } (GJ/apartment) & $(\$ / G J)$ & $(\$ / G J)$ & $(\$ / G J)$ \\
\hline Philadelphia & 25.6 & 3.31 & 8.00 & 4.69 \\
Atlanta & 34.2 & 2.48 & 8.00 & 5.52 \\
Chicago & 24.8 & 3.42 & 8.00 & 4.58 \\
Minneapolis & 20.9 & 4.06 & 8.00 & 3.94 \\
Dallas & 50.6 & 1.68 & 8.00 & 6.32 \\
\hline
\end{tabular}

VII. ASSESSMENT OF THE THERMAL GRID CONCEPT

The intent of this assessment is to determine if supply of regional heat from a dual purpose power plant is feasible for the various consuming sectors examined. Based on economic and technical considerations, the various applications for heat from the thermal grid are ranked in their order of importance.

Institutional and technical barriers to implementation are examined and factors to be considered in further studies are discussed.

\section{Eronomic Assesement}

The overall economic assessment of the concept incorporates the costs and breakeven prices developed in the previous sections of this Eupurt. Hcar oupply costs used in the overall assessment have been taken from Table 4.7. Long distance transmission costs from Sect. 4 and subregion distribution costs from Table 5.8 and Fig. 5.3 were used to determine the heat transport costs. Breakeven prices wcre taken from Tables 6.5, 6.7-6.11, and 6.13.

As a basis for the overall economic assessment, the use of heat from a thermal grid has been compared to oil fired systems for new (as opposed 
to retrofit) applications. Breakeven prices and subregion distribution costs for the consuming regions under study are presented in Table 7.1. The difference between them essentially represents the maximum allowable cost for supply and long distance transmission of thermal grid heat to be competitive with the oil fired systems. Using this cost difference the maximum distance of heat transmission for the various heat supply systems has been computed.

Table 7.1. Maximum allowable cost for heat generation and distribution ${ }^{a}$

\begin{tabular}{|c|c|c|c|}
\hline Application & $\begin{array}{c}\text { Breakeyen } \\
\text { cost } \\
(\$ / G J)\end{array}$ & $\begin{array}{c}\text { Subregion } \\
\text { distribution } \\
(\$ / G J)\end{array}$ & $\begin{array}{c}\text { Cost } \\
\text { difference } \\
(\$ / G J)\end{array}$ \\
\hline \multicolumn{4}{|c|}{$\begin{array}{l}\text { Multifamily - commercial } \\
\text { Philadelphia }\end{array}$} \\
\hline $\begin{array}{l}\text { Two story } \\
\text { Three story }\end{array}$ & $\begin{array}{l}7.24 \\
7.59\end{array}$ & $\begin{array}{l}1.64 \\
1.15\end{array}$ & $\begin{array}{l}5.60 \\
6.44\end{array}$ \\
\hline \multicolumn{4}{|l|}{ Atlanta } \\
\hline Two story & 7.43 & 1.81 & 5.62 \\
\hline & Chicago & 1.27 & 5.82 \\
\hline $\begin{array}{l}\text { Two story } \\
\text { Three story }\end{array}$ & $\begin{array}{l}7.29 \\
7.59\end{array}$ & $\begin{array}{l}1.46 \\
1.05\end{array}$ & $\begin{array}{l}5.83 \\
6.54\end{array}$ \\
\hline \multicolumn{4}{|l|}{ Minneapolis } \\
\hline Two story & 7.20 & 1.22 & 5.98 \\
\hline Three story & 7.47 & 0.89 & 6.58 \\
\hline \multicolumn{4}{|l|}{ Dallas } \\
\hline Two story & 7.48 & 2,02 & 5.46 \\
\hline Three story & 7.94 & 1.41 & 6.53 \\
\hline \multicolumn{4}{|l|}{ Single family } \\
\hline Philadelphia & 6.77 & 5.32 & 1.45 \\
\hline Atlanta & 6.82 & 5.32 & 1.50 \\
\hline Chicago & 6.74 & 5.32 & 1.42 \\
\hline Minneapolis & 6.69 & 5.32 & 1.37 \\
\hline Dallas & 6.78 & 5.32 & 1.46 \\
\hline \multicolumn{4}{|l|}{ Industrial } \\
\hline $63 \mathrm{~kg} / \mathrm{s}$ & 2.84 & 0.07 & 2.77 \\
\hline $126 \mathrm{~kg} / \mathrm{s}$ & 2.79 & 0.05 & 2.74 \\
\hline $252 \mathrm{~kg} / \mathrm{s}$ & 2.78 & 0.04 & 2.74 \\
\hline
\end{tabular}


The maximum allowable heat supply and transmission costs in Table 7.2 were obtained by averaging the cost difference figures for the applications considered in Table 7.1. The average cost, representing a national average, is probably more meaningful than any of the individual costs in Table 7.1 for the purposes of this study. Therefore, this cost is most meaningful for a study of this scope. The maximum transmission distance was computed assuming heat was supplied to the grid at $150^{\circ} \mathrm{C}\left(350^{\circ} \mathrm{F}\right)$ and high temperature hot water was used as the transport medium. As discussed previously, a reboiler will probably be required for the coal systems. Therefore, the heat supply cost (from Table 4.8) used in computing the maximum transmission distance included the cost for a reboiler.

Table 7.2. Maximum economic heat transmission distance for supply of space and hot water heating for new applications ${ }^{a}$

\begin{tabular}{|c|c|c|c|c|}
\hline \multirow[t]{2}{*}{ Application } & \multirow{2}{*}{$\begin{array}{l}\text { Maximum allowable } \\
\text { supply and trans- } \\
\text { mission cost } \\
(\$ / G J)\end{array}$} & \multicolumn{3}{|c|}{$\begin{array}{l}\text { Maximum transmission distance fc } \\
\text { indicated heat supply } b \\
(\mathrm{~km})\end{array}$} \\
\hline & & PWR & $\begin{array}{c}\text { Low sulfur } \\
\text { coal }\end{array}$ & $\begin{array}{c}\text { High sulf } \\
\text { coal }\end{array}$ \\
\hline $\begin{array}{c}\text { Mu1tifamily - } \\
\text { mommerctal }\end{array}$ & & & & 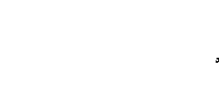 \\
\hline $\begin{array}{l}\text { Two story } \\
\text { Three story }\end{array}$ & $\begin{array}{l}5.70 \\
6.38\end{array}$ & $\begin{array}{l}67 \\
70\end{array}$ & $\begin{array}{l}66 \\
75\end{array}$ & $\begin{array}{l}64 \\
74\end{array}$ \\
\hline Single family & 1.44 & 5 & 10 & 8 \\
\hline Industrial & 2.75 & 22 & 27 & 26 \\
\hline
\end{tabular}

The results in Table 7.2 indicate that the thermal grid can supply heat to the multifamily residential-commerclal sector using heat from a power plant $64 \mathrm{~km}$ ( 40 miles) from the consuming sector and be economically competitive with oil fired systems. Similar results for the single family residence and industrial sector indicate transmission distances of 8 and 
$25.6 \mathrm{~km}$ ( 5 and 16 miles), respectively, result in thermal grid heat being competitive with oil fired systems.

Of interest in Table 7.2 is the relative insensitivity of the transmission distance to the heat supply system. It appears that coal and nuclear based systems would offer about the same potential for supply of heat to the grid.

Another interesting, although not unexpected, feature illustrated in Table 7.2 is the sensitivity of the transport distance to the heat demand density. Thermal grid heat is most competitive for the 3 story multifamily residential-commercial sector. This is followed by the 2 story multifamily residential-commercial sector and the industrial sector. Although the industrial sector has the greatest energy demand density, the relatively low heat costs for this sector resulted in a low breakeven price and a correspondingly shorter allowable transmission distance. Because of its low heat demand density, the single family residential sector had the shortest allowable transmission distance.

The sensitivity of the maximum transmission distance to the type of fuel, hence breakeven price, used in the sector is illustrated in Table 7.3 for a new application for 2. story apartments in Philadelphia. These results indicate that the maximum transmission distance is directly related to the breakeven price. Since the fuel cost is a major component of the breakeven price, it is evident that the thermal grid is most competitive with residential-commercial systems that have high fuel costs (i.e. electricity and oil).

As discussed in Sect. 6, the fuel cost for industrial systems using coal depends on the coal transport cost. It is expected that in actual practice industrial steam costs using coal-fired units will equal or exceed those for oil-fired systems. 45 Therefore, for the purposes of this report the thermal grid will be considered to be of equal feasibility when compared to industrial systems using coal or oil.

The results of a similar analysis for retrofit applications is presented in Table 7.4. It is interesting to note that the maximum allowable transmission distances for the multifamily residential-commercial and industrial sectors are not significantly decreased. In the residentialcommercial sector this is because the alternate conventional system 
Table 7.3. Maximum transmission distance for Philadeiphia - $i$ story apartments

\begin{tabular}{|c|c|c|c|c|c|c|}
\hline \multirow{2}{*}{ Fu $\in 1$} & \multirow{2}{*}{$\begin{array}{c}\text { Breakeven } \\
\text { cost } \\
(\$ / G J)\end{array}$} & \multirow{2}{*}{$\begin{array}{c}\text { Dis=ribution } \\
\text { cost } \\
(\$ / G J)\end{array}$} & \multirow{2}{*}{$\begin{array}{c}\text { Maximum cost } \\
\text { for gereration } \\
\text { anc trarsmission } \\
(\$ / G J)\end{array}$} & \multicolumn{3}{|c|}{$\begin{array}{l}\text { Maximum allowable transmission distance } \\
\text { for indicated heat supply }(\mathrm{km})^{a}\end{array}$} \\
\hline & & & & PDR & $\begin{array}{l}\text { High sulfur } \\
\text { coal }\end{array}$ & $\begin{array}{l}\text { Low sulfur } \\
\text { coal }\end{array}$ \\
\hline Electric & $12 . \dot{44}$ & 1.64 & 10.80 & 130 & 133 & 134 \\
\hline Oil & 7.24 & 1.64 & 5.60 & 61 & 64 & 64 \\
\hline Gas & 3.23 & 1.64 & 1.59 & 8 & $\Xi J$ & 10 \\
\hline
\end{tabular}

$a_{\text {Heat }}$ generation costs from Zable 4.7 . ETHW transmission at $7 \mathrm{c} / \mathrm{G}^{-}-\mathrm{km}$. 
Table 7.4. Maximum transmission distance for retrofit applications ${ }^{a}$

\begin{tabular}{|c|c|c|c|c|c|c|}
\hline \multirow{2}{*}{ Application } & \multirow{2}{*}{$\begin{array}{c}\text { Breakeven } \\
\text { cost }^{b} \\
(\$ / G J)\end{array}$} & \multirow{2}{*}{$\begin{array}{c}\text { Subrejion } \\
\text { distribution } \\
\text { cost }^{C} \\
(\$ / G J)\end{array}$} & \multirow{2}{*}{$\begin{array}{c}\text { Maximum cost for } \\
\text { generation and } \\
\text { transmission } \\
(\$ / G J)\end{array}$} & \multicolumn{3}{|c|}{$\begin{array}{c}\text { Maximum transmission distance for } \\
\text { heat source }(\mathrm{km}) d\end{array}$} \\
\hline & & & & PWR & $\begin{array}{l}\text { High sulfur } \\
\text { coal }\end{array}$ & $\begin{array}{c}\text { Low sulfur } \\
\text { coal }\end{array}$ \\
\hline \multicolumn{7}{|l|}{$\begin{array}{l}\text { Multifamily - } \\
\text { commercial }\end{array}$} \\
\hline $\begin{array}{l}\text { Philadelphia } \\
\text { Atlanta } \\
\text { Chicago } \\
\text { Minneapolis } \\
\text { Dallas }\end{array}$ & $\begin{array}{l}6.40 \\
6.40 \\
6.40 \\
6.40 \\
6.40\end{array}$ & $\begin{array}{l}1.17 \\
1.40 \\
1.13 \\
0.88 \\
1.63^{3}\end{array}$ & $\begin{array}{l}5.23 \\
5.00 \\
5.27 \\
5.52 \\
4.77\end{array}$ & $\begin{array}{l}56 \\
53 \\
56 \\
59 \\
50\end{array}$ & $\begin{array}{l}58 \\
54 \\
58 \\
61 \\
51\end{array}$ & $\begin{array}{l}59 \\
56 \\
59 \\
62 \\
53\end{array}$ \\
\hline $\begin{array}{l}\text { Single family } \\
\text { Philadelphia } \\
\text { Atlanta } \\
\text { Chicago } \\
\text { Minneapolis } \\
\text { Dallas }\end{array}$ & $\begin{array}{l}5.13 \\
4.98 \\
5.45 \\
5.56 \\
4.77\end{array}$ & $\begin{array}{l}5.32 \\
5.32 \\
5.32 \\
5.32 \\
5.32\end{array}$ & $\begin{array}{r}-0.19 \\
-0.34 \\
0.13 \\
0.24 \\
-0.55\end{array}$ & $\begin{array}{l}0 \\
0 \\
0 \\
0 \\
0\end{array}$ & $\begin{array}{l}0 \\
0 \\
0 \\
0 \\
0 \\
0\end{array}$ & $\begin{array}{l}0 \\
0 \\
0 \\
0 \\
0\end{array}$ \\
\hline $\begin{array}{l}\text { Industrial } \\
\qquad 3 \mathrm{~kg} / \mathrm{s} \\
126 \mathrm{~kg} / \mathrm{s} \\
252 \mathrm{~kg} / \mathrm{s}\end{array}$ & $\begin{array}{l}2.55 \\
2.56 \\
2.57\end{array}$ & $\begin{array}{l}0.07 \\
0.05 \\
0.04\end{array}$ & $\begin{array}{l}2.48 \\
2.51 \\
2.53\end{array}$ & $\begin{array}{l}19 \\
19 \\
19\end{array}$ & $\begin{array}{l}21 \\
21 \\
21\end{array}$ & $\begin{array}{l}22 \\
22 \\
22\end{array}$ \\
\hline $\begin{array}{l}a_{\text {Compared }} \\
b_{\text {From Tabl }} \\
c_{\text {From Tabl }} \\
d_{\text {Heat gene }}\end{array}$ & $\begin{array}{l}\text { il based } \\
.5,6.7 \text {, } \\
2 \text { and Fig }\end{array}$ & $8,6.9,6.10$, & 6.11 and 6.13 & & & \\
\hline
\end{tabular}


essentially utilized the same building distribution equipment that would be required to use heat from the thermal grid system. Therefore, additional expenses to hook up to the thermal grid are minimal. The importance of these additional costs is illustrated in the single family residential sector. Because of the additional equipment costs, retrofitting single family residences to utilize heat from the thermal grid is not feasible unless the dual purpose generating station was located within the sector.

The multifamily residential-commercial sector distances indicated in Table 7.4 are probably optimistic estimates. As mentioned in Sect. 5, the subregion piping costs are not indicative of inner city construction where streets must be disturbed and pipe routing problems exist. Therefore, it is probable that the actual economically feasible distances, which depend on local conditions, could be much shorter than those indicated in Table 7.4 .

The maximum allowable distances to serve the industrial subregion are relatively unchanged for new and retrofit applications. Since essentially no retrofit equipment is required for the assumed industrial model, the only difference between the two applications is replacement of the boiler when considering new applications. The industrial distances in Table 7.4 are expected to be fairly realistic since the subregion distribution piping situation is expected to be the same for new and retrofit applications.

Economic assessment of supplying chilled water incorporated the subregion distribution costs from Table 5.12, the breakeven prices from lable 6.14 and the heat supply costs from Table 4.9. As discussed in Sect. 5, hot water from the grid is flashed and the resulting steam used to drive a turbine driven water chiller unit. The subregion distribution costs include both generation and distribution of the chilled water.

The maximum distance between the power plant and the consuming region that allows chilled water from the grid to compete with standard air conditioning systems is presented in Table 7.5 for 2 story apartment buildings in Philadelphia for new applications. As stated in Sect. 5, the single family residential sector was not considered because of excessive distribution costs. 
Table 7.5. Maximum transmission distance for supply of chilled water for new applications

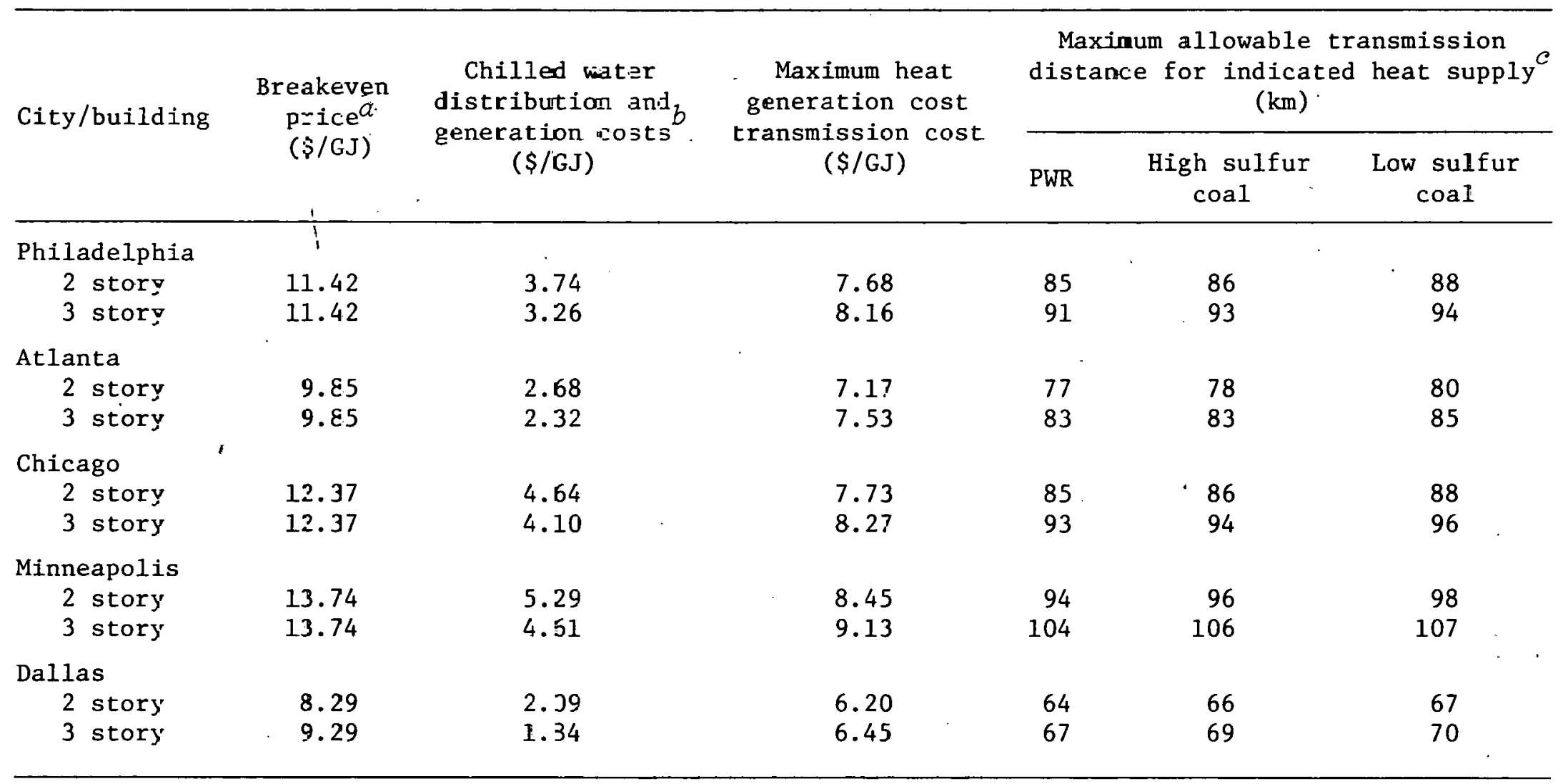

$a_{\text {From Table } 6.14}$

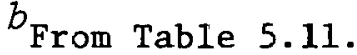

${ }^{c} 400^{\circ} \mathrm{F}$ supply $\left(200^{\circ} \mathrm{C}\right)$. Eleat gener 
In determining the distances in Table 7.5 it was assumed that high temperature hot water transport was used and heat is supplied to the long distance line at $200^{\circ} \mathrm{C}\left(400^{\circ} \mathrm{F}\right)$.

The distances in Table 7.5 are on the order of those for the heating option when compared to oil systems. These relatively long distances are a result of the high cost of electricity to drive the air conditioning units.

Analysis of Table 7.5 indicates that the distance is sensitive to the demand density ( 2 story versus 3 story) and climatic factors. It is interesting to note that district chilled water is less economic in warmer climates for new applications. This is because under the new HUD standards the peak cooling demand shows little variation for the various climates. Therefore, the capital investment for each location is approximately the same. Since the yearly cooling load is much larger for the warmer climates, the unit cooling cost is lower. This lower unit cost results in a lower breakeven price and a correspondingly shorter maximum allowable transmission distance.

The results of a similar analysis for retrofit applications is presented in Table 7.6. These results indicate a very strong dependence on climate. For areas having cooler climates (Philadelphia, Chicago and Minneapolis) this application of retrofitting the multifamily residentialcommercial sector to utilize district chilled water is not feasible. For warmer climates (Atlanta and Dallas), this application is feasible, however, at reduced distances when compared to new applications. As in the heating case however, the subregion distribution costs are probably lower than would actually be incurred. It is possible that increased distribution costs would result in this application becoming infeasible. Therefore, for the purposes of this study retrofit applications will be considered infeasihle.

\section{Assessment of Applications}

The preceding economic assessment provides some general guidelines for determining which sectors should be served by the thermal grid. 
Table 7.6. Maximum transmission distance for supply of chilled water for retrofit applications

\begin{tabular}{|c|c|c|c|c|c|c|}
\hline \multirow{2}{*}{ City/building } & \multirow{2}{*}{$\begin{array}{c}\text { Breakeven } \operatorname{cost}^{a} \\
(\$ / G J)\end{array}$} & \multirow{2}{*}{$\begin{array}{l}\text { Subreqion } \\
\text { distritution } \\
\text { cost } b \\
(\$ / G J)\end{array}$} & \multirow{2}{*}{$\begin{array}{c}\text { Maximum allowable } \\
\text { heat generation and } \\
\text { transmission cost } \\
(\$ / G J)\end{array}$} & \multicolumn{3}{|c|}{$\begin{array}{l}\text { Maximum transmission distance for } \\
\text { indicated heat source }(\mathrm{km})^{c}\end{array}$} \\
\hline & & & & PWR & $\begin{array}{l}\text { High sulfur } \\
\text { coal }\end{array}$ & $\begin{array}{c}\text { Low sulfur } \\
\text { coal }\end{array}$ \\
\hline \multicolumn{7}{|l|}{ Philadelphia } \\
\hline 2 story & 4.69 & 2.59 & 2.10 & 13 & 16 & 18 \\
\hline 3 story & 4.69 & 2.32 & 2.37 & 18 & 19 & 38 \\
\hline \multicolumn{7}{|l|}{ Atlanta } \\
\hline 2 story & 5.52 & 1.78 & 3.74 & 35 & 38 & 38 \\
\hline 3 story & 5.52 & 1.57 & 3.95 & 38 & 40 & 42 \\
\hline \multicolumn{7}{|l|}{ Chicago } \\
\hline 2 story & 4.58 & 2.83 & 1.75 & 10 & 11 & 13 \\
\hline 3 story & 4.58 & 2.55 & 2.03 & 13 & 14 & 16 \\
\hline \multicolumn{7}{|l|}{ Minneapolis } \\
\hline 2 story & 3.94 & 3.17 & 0.77 & 0 & 0 & 0 \\
\hline 3 story & 3.94 & 2.84 & 1.10 & 0 & 3 & 3 \\
\hline \multicolumn{7}{|l|}{ Dallas } \\
\hline 2 story & 6.32 & 1.36 & 4.96 & 51 & 54 & 56 \\
\hline 3 story & 6.32 & 1.23 & 5.08 & 53 & 56 & 58 \\
\hline
\end{tabular}

$a_{\text {From Table 6.15: }}$

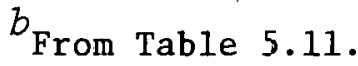

${ }^{c}$ Heat generation cost from Table 4.7 and HTHW transmission at $7 c / G J-k m$. 
The economic assessment indicated that new applications are favored over retrofit situations except possibly for the industrial subregion where both applications are of about equal merit. Therefore, thermal grid implementation should concentrate on new applications for the multifamily residential and commercial sectors but can include new and retrofit applications in the industrial sector.

Since the maximum transmission distance for the single family residential sector is short (on the order of $6 \mathrm{~km}$ ( 9.6 miles) for new and $0 \mathrm{~km}$ for retrofit applications], it is unlikely that a large generating station would be within the maximum allowable transmission distance for this sector. Therefore, it is unlikely that this sector would be served by the thermal grid.

The assessment has also indicated that feasibility of the concept depends on the prevailing fuel used in the consuming sector. For the multifamily residential-commercial sector the thermal grid is competitive with oil and electric based systems. The maximum allowable transmission distances presented in Table 7.3 indicate that the thermal grid would probably not be competitive with gas-fired systems in the sector. It also appears that the thermal grid is competitive in the industrial sector when compared to oil or coal based systems. Therefore, thermal grid implementation could concentrate on areas where these fuels dominate. It should be noted that because of supply uncertainties, price increases and recent legislation many industries are converting from gas tn nil $\mathrm{nr}$ coal systems. Areas where this conversion is taking place are of special interest because they would essentially fit into the new application classification.

Economic and technical criteria further indicațe the desired load profile of the service area. The long distance transmission line capacity tactor should be kept as close as possible to unity to keep transmission costs to a minimum. Therefore, industrial customers should form the base load for the thermal grid. Their relatively constant heat demand would result in a fairly constant base load. Since heat is being supplied from a dual purpose power plant, this constant base load could also reduce power plant operating problems associated with following the heat load. 
Although the economic analysis indicated a shorter economic transmission distance for the industrial sector, this should not be a serious problem since large industrial sites are generally located on the outskirts of cities. Therefore, the industrial region is usually sited in the same general area as large scale power generating stations and transmission distances would probably be within the maximum economic distance.

Building on the industrial base load, the economic assessment indicates that the multifamily residential-commercial load could be added to. the system. Addition of this load will impose a small additional base load, associated with hot water demands, and a larger variable load for space conditioning. Therefore, the total load will consist of a base load portion and a seasonal component. If the industrial load is dominant, the seasonal component may be small in comparison to the base load. This would simplify the operating procedures of the power plant in meeting both heat and power demands.

The economic analysis indicated that the multifamily-commercial sector alone could be served by a thermal grid. However, serving this sector alone or a load dominated by this sector could detrimentally affect the operation of the power plant. Meeting large scale yearly and daily fluctuations in heat demand may require sophisticated load following control equipment. Specially designed turbo-generator units may also be required. Therefore, it appears that these applications are not as favorable as the industrial dominated load pattern previously discussed.

The economic analysis of district chilled water supply indicated that chilled water systems could be installed in conjunction with district heat systems that competed with traditional heating systems using oil or electricity. Implementing such a system would add to the summer demand, increase the use factor of the transmission pipeline and reduce the seasonal load variation. This would enhance the proposal to supply the residential-commercial dominant market. However, low heat demand during the spring and fall results in the industrial dominant load pattern being favored.

The system load will, therefore, consist of industrial and multifamily residential-commercial customers and can be structured in either of two configurations. The first links the two consuming sectors. In 
this configuration relatively high temperature heat [above $149^{\circ} \mathrm{C}\left(300^{\circ} \mathrm{F}\right)$ ] is supplied to the industrial sector and moderate temperature [about $\left.149^{\circ} \mathrm{C}\left(300^{\circ} \mathrm{F}\right)\right]$ reject heat from the industrial sector is then transported to the residential-commercial sectors. In the second configuration the two sectors are independent and heat is supplied to each sector directly from the thermal grid. Site specific conditions would determine which of the two configurations was most economically attractive.

This assessment has indicated that heat from a thermal grid could successfully compete with traditional oil and electric systems in the multifamily residential-commercial sector to meet space and domestic water heating demands. Supply of chilled water was also found to be a feasible option for this sector. Industrial process steam could also be supplied economically by the thermal grid when compared to coal- or oil-fired systems. A system using an industrial base load is preferred because of the relatively constant load profile. Supply of the multifamily residential-commercial dominated load, however, is also a feasible option.

\section{Institutional Considerations Concerning Implementation}

Several institutional considerations should be explored in conjunction with the thermal grid concept. At the present time district heating systems in the United States have generally been only marginally profitable. Because of the large investments required, especially in the distribution system, regulatory issues should be addressed to allow larger profit margins. This could spur interest in the concept and promote its ut1lization.

Because both heat and electricity are produced in a dual purpose generating station, institutional considerations within the utility and the regulatory agency are raised. Most utilities have separate organizations and facilities for thelr district hearing and electrical generating sections. These two organizations must be brought into close communication and must function together if the thermal grid concept is to be implemented.

At the present time, regulatory agencies treat the utility's electrical and district heating systems independently. However, cogeneration of heat and electricity results in a dependence between the two 
commodities. Therefore, regulatory agencies will have to revamp their rate setting methods to account for this dependence.

\section{Factors to be Considered in Further Studies}

In addition to the institutional considerations outlined in the previous section, future programs should focus on site specific studies of three regions. The three regions would include an industrial dominant market, a residential-commercial dominant market and a mixed load market. These studies would provide detailed information concerning load patterns and economic feasibility and should investigate load growth strategies.

The load growth strategy study could focus on the European method of building the system. This method builds the system using oil-fired boilers during the early stages of growth. When the load is sufficient to justify. using heat from a dual purpose power plant, the oil- or coal-fired boilers are used as standby units and for meeting demand peaks. Exploration of this strategy could determine the base load necessary to justify heat from a dual purpose unit. It could also determine the amount of load fluctuation that could be met with the dual purpose station and the amount that should be met with oil- or coal-fired peaking stations.

The site specific studies may indicate the need for new equipment or significant improvements in available hardware. This will probably be evident when studying the cogeneration concept. It is not likely that back pressure turbines of sufficient size are now commercially available. Therefore, designs and costs for these items may have to be developed.

The role of thermal storage in the system will also require definition. Heat storage could serve to flatten the daily load cycle by storing heat during periods of low demand and supplementing a base load value during periods of high demand. This technique could essentially reduce the fluctuations necessary on the supply side and increase the heat supply base load value. 


\section{REFERENCES}

1. Federal Energy Administration, Project Independence Report, Project Independence, pp. 154-171, November 1974.

2. L. H. Crump and C. L. Readling, "Fuel and Energy Data, United States by States and Regions, 1972," U.S. Department of Interior, Bureau of Mines Information Circular 8647, 1974.

3. A. Doernberg, "Comparative Analysis of Energy Use in Sweden and the United States," Brookhaven National Laboratory Report BNL-20539 (February 1977).

4. The Potential Industrial Market for Process Heat from Nuclear Reactors, prepared for Oak Ridge National Laboratory by Dow Chemical, ORNL/SUB-4384 (January 1976).

5. T. D. Anderson et a1., A Comparative Assessment of Industrial Energy Options Based on Coal and Nuclear Systeme, ORNL-4995 (July 1975).

6. P. Margen, "The Use of Heat from Nuclear Stations for Residential Heating," presented ASME/ANS International Conference, Pittsburgh, Pennsylvania, March 13-16, 1976.

7. H. Winkens, "Germany Looks Towards Nuclear District Heating," Energy International, pp. 17-20 (August 1975).

8. District Heating Handbook, 3rd ed., National District Heating Association, Pittsburgh, Pennsylvania, 1949.

9. Proceedings of Sixty-Fifth Annual Meeting of the International District Heating Asssociation, Cooperstown, N. Y., June 24-26, 1974.

10. Ellwood Clymer, President IDHA, personal communication to M. Olszewski, Oak Ridge National Laboratory, January 1976.

11. Detroit Edison Company, personal communication to M. Olszewski, February 1976.

12. L. Smith, "The Hartford Story," Heating, Piping and Air Conditioning, pp. 114-121 (September 1964).

13. L. Smith, "Allegheny Center: D1str1ct Ch1lled Water to Stores, offices, and Homes," Heating, Piping and Air Conditioning, pp. 118-122 (July 1965).

14. Anon., "Co-op City in the Bronx," Engineering (Mar. 29, 1968).

15. C. Easton, Seattle Steam Corp., personal communication to M. Olszewski, Oak Ridge National Laboratory, January 1976.

16. T. Torre, Consolidated Edison, personal communication to J. G. Delene, Oak Ridge National Laboratory, January 1976.

i7. L. luck, Boston Edison, personal communicarion to J. G. Delene, Oak Ridge National Laboratory, January 1976.

18. Anon., "Nashville Turns Solid Waste Into District Steam and Chilled Water," Power, pp. 18-19 (December 1974). 
19. Anon., "How Europe's Trash Technology Benefits GE," Business Week, p. 36 (Oct. 6, 1975).

20. N. Witenbrock, Battelle Northwest, personal communication to M. Olszewski, Oak Ridge National Laboratory, January 1976.

21. E. A. Haseler, "Why Waste All That Heat?" District Heating 60(4), 22-26 (April-June 1975).

22. R. A. Learmonth, "Keeping Whole Towns Warm," Heating and Ventilating Engineer 46, 565 (May 1973).

23. Peter H. Margen, "A Future Trend in District Heating? The Economic Relevance of Regional Nuclear District Heating Schemes," Energy World (7), 11-14 (July 1974).

24. Peter H. Margen. "The Use of Heat from Nuclear Stations for Residential Heating," presented ASME/ANS International Conference, Pittsburgh, Pennsylvania, March 13-16, 1976.

25. M. Mühlhäuser and W. Hebling, "Heating from Nuclear Power Stations," Sulzer Technical Review 3, 157-164 (1975).

26. Ye. Ya. Sakolov, "Current State of the Introduction of District Heating Systems in the USSR and the Prospects for Their Development During 1971-1975," Heat Transfer - Soviet Research 6(2), 1-11 (1974).

27. I. Spiewak, Oak Ridge National Laboratory, personal communication to M. Olszewski, Oak Ridge National Laboratory, January 1976.

28. D. F. Woodyard, "District Heating Now," Engineering 211(6), 639-642 (September 1971).

29. Peter H. Margen, "District Heating Development Work in Sweden," AE-VS-159 (May 1975).

30. Eric Jeffs, "Sweden's Nuclear Policy Holds Back on District Heating," Energy Intemational, pp. 19-2i (Óctober 1y/b).

31. Anon., "Denmark Leads in District Heating," District Heating 60(1), 14-21 (July/September 1974).

32. S. T. Brewer et al., CONCEPT: A Computer Code for Conceptual losts Estimates of Steam-Electric Power Plant.s, ERDA-108 (June 1975).

33. S. T. Brewer et al., A Procedure for Estimating Non-Fuel operating and Maintenance Costs for Large Steam-Electric Power Plants, ERDA 76-37 (October 1975).

34. T. D. Anderson et al., An Exploratory Study of Cost Targets for Solar Electric Power Plants, ORNL/TM-5787 (March 1977).

35. C. C. Haws, Oak Ridge National Laboratory, personal communication to M. O1szewski, October, 1976.

36. E. Clymer, "President Clymer Responds to Energy International Magazine," District Heating, pp. 7-9 (October-December 1975).

37. W. R. Mixon et al., Technology Assessment of Modular Integrated Utility Syctome, ORNL/TM (to be published). 
38. J. T. Meador, MIUS Technology Evaluation - Thermal Energy Conveyance, ORNL/HUD/MIUS-29 (May 1976).

39. J. Karkheck et al., The Technical and Economic Feasibility of U.S. District Heating Systems Using Waste Heat from Fusion Reactors, BNL 50516, Brookhaven National Laboratory (February 1976).

40. Commercial - Industrial-Estimating and Engineering Standards, Richardson Englneering Services, Inc., Downey, Californ1a, 1975.

41. R. G. Werden and L. G. Spielvogel, Sixing of Service Water Heating Equipment in Commercial and Industrial Buildings, Report No. 2, Edison Electric Institute (June 1969).

42. JSHRAE Guide and Data Book, Systems, American Society of Heating, Refrigeration, and Air Conditioning Engineers, New York, 1973.

43. R. S. Means, Building Construction Cost Data 1976, 34th Annual Ed., Robert Snow Means Company, Duxbury, Massachusetts, 1975.

44. J. G. Delene and J. B. Gaston, A Regional Comparison of Savings from Various Residential Energy Conservation Strategies, ORNL/TM-5146 (February 1976).

45. E. C. Fox, Oak Ridge National Laboratory, personal communication to M. Olszewski, Oak Ridge National Laboratory, June 1977. 
ORNL/TM-5786

$\underline{\text { Internal Distribution }}$

1. T. D. Anderson

2. S. Baron

3. S. E. Beal1

4. J. E. Christian

5. W. B. Cottrell

6. F. L. Culler

7. J. G. Delene

8. G. G. Fee

9. E. C. Fox

10. W. K. Fulkerson

11. J. F. Harvey

12. R. F. Hibbs

13. H. W. Hoffman

14. M. A. Karnitz

15. 0. H. Klepper

16. M. Levenson

17. R. E. MacPherson
18. J. T. Meador

19. W. J. McCarthy, Jr.

20-54. M. O1szewski

55. H. Postma

56. M. W. Rosenthal

57. T. H. Row

58. M. R. Sheldon

59. M. J. Skinner

60. I. Spiewak

61. J. J. Taylor

62. D. B. Trauger

63. G. D. Whitman

64-65. Central Research Library

66. Document Reference Section

67-68. Laboratory Records Department

69. Laboratory Records, RC

\section{External Distribution}

70-71. Director, Division of Nuclear Research and Application, ERDA Washington

72. Director, ERDA, ORO

73. Research and Technical Support Division, ERDA, OR

74-100. Technical Information Center, OR

101. D. Linz, ERDA, NR.

102. W. F. Savage, DNRA, ERDA; Washington

103. S. N. Cavros, Division of Building and Community Systems, ERDA Washington

104. M. Gottlieb, Division of Environmental Control Technology, ERDA Washington

105. D. R. Israe1, Office of Programs Integration, ERDA, Washington

106. R. G. Oehl, Division of Nuclear Research and Applications, ERDA Washington

107. A. J. Streb, Division of Industrial Energy Conservation, ERDA, Washington

108. Sidney Berwager, FEA, 12th and Pennsylvania Avenue, Washington, DC 20461

109. Robert McFarren, FEA, 12th \& Pennsylvania Avenue, Washington, DC 20461

110. M. B. Barnes, State of Minnesota Energy Agency, 740 American Center Building, 150 East Kellogg Blvd., St. Pau1, MN 55101

111. P. H. Margen, AB Atomenergi, Flack, 61101 Nykoping 1, Sweden

112. J. C. Pearce, Northern States Power Co., 411 Nicollet Ma11, Minneapolis, MN 55401

113. V. Kab1, Argonne National Laboratory 
114. W. Soderberg, Director of Physical Plant, 200 Shope Building, University of Minnesota, Minneapolis, MN 55455

115. R. W. Thron, 300 Metro Square Building, 7th and Robert, St. Paul, MN 55101

116. W. L. Waleen, Minnesota Gas Company, 9525 Wayzata Boulevard, Minneapolis, MN 55426

117. D. H. Brandt, Donald H. Brandt Associates, 10101 Snow Road, Horton, MI 49246

118. E. A. Clymer, Philadelphia Electric Company, 2301 Market Street, Philadelphia, PA 19101

119. C. W. Easton, Seattle Steam Corporation, 1205 Peoples National Bank Building, Seattle, WA 98171

120. H. Jaehne, Northern States Power Company, 411 Nicollet Mall, Minneapolis, MN 55401

121. K. Linwick, IDS Properties, 2500 IDS Center, Minneapolis, MN 55402

122. H. E. Nurmi, Detroit Edison Company, 2000 Second Avenue, Detroit MI 48226

123. G. L: Reichert, Northwestern University, Central Utilities Plant, 2025 Sheridan Road, Evanston, IL 60201

124. F. Strnisa, New York State Energy Agency, Swan Street Building, Empire State Place, Albany, NY 12223

125. R. Tourin, New York State ERDA, 230 Park Avenue, New York, NY 10117

126. J. P. Karkheck, Building 129, Brookhaven National Laboratory, Upton, NY 11973

127. R. Pohl, Department of Physis, Clark Hall, Cornell University, Ithaca, NY $1 / 853$ 